
Historic, archived document

Do not assume content reflects current scientific knowledge, policies, or practices. 
UNITED STATES

DEPARTMENT OF AGRICULTURE LIBRARY

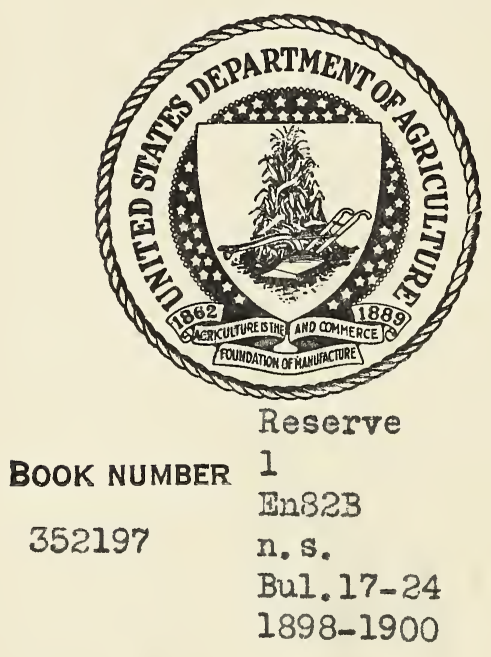






BULLETIN NO. 17-NEW SERIES.

U. S. DEPARTMENT OF AGRICULTURE.

DIVISION OF ENTOMOLOGY.

PROCEEDINGS

OF - THE

TENTH ANNUAL MEETING

OF THE

\section{ASSOCLTION OF ECONOVIIC ENTOUIOLOGISTS.}

WASHINGTON:

GOVERNMENT PRINTING OFFICE. 1898 . 


\section{DIVISION OF ENTOMOLOGY.}

Entomologist: L. O. Huward.

Assist. Entomologists: C. L. Marlatt, Th. Pergande, F. H. Chittenden, Frank Benton. Investigators: E. A. Schwarz, H. G. Hubbard, D. W. Cornillett.

Assistants: R. S. Clifton, Nathan Banks, F. C. Pratt, A. Busck, Otto Heidemann. Artist: Miss L. Sullivan. 
Bulletin No. 17-NeW SERIES.

U. S. DEPARTMENT OF AGRICULTURE.

DIVISION OF ENTOMOLOGY.

\section{PROCEEDINGS}

OF THE

TENTH ANNUAL MEETING

OF THE

\section{ASSOCLATIOI OF ECONOVIIC ENTOUIOLOGISTS.}

WASHINGTON:

GOVERNIENT PRINTING OFFICE.

1898. 


\section{LETTER OF TRANSIITTAL.}

U. S. Departinent of Agriculture, Division OF ENTOMIOLOGY, Washington, D. C., October 6, 1898.

SIR: I have the honor to transmit herewith the manuscript of the report prepared by the secretary, Mr. C. L. Marlatt, of the proceedings of the tenth annual meeting of the Association of Economic Entomol. ogists, which was held at Boston, Mass., August 19 and 20, 1898. The proceedings of this association are of the greatest economic importance, and the secretary's reports have hitherto been published in bulletins of this division. I therefore recommend the publication of the present report as Bulletin No. 17, new series.

Respectfully,

Hon. Jaires Wilson,

Secretary of Agriculture.
L. O. HoWARD, Entomologist.

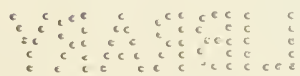


Tenth Annual Meeting of the Association of Econonic Entomolo-

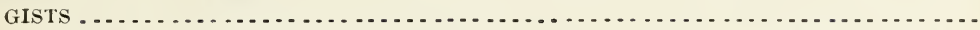

The Duty of Economic Entomology ................... Herbert Osborn..

Two Beneficial Insects Introduced from Europe (illustrated)............

L. O. Howard..

Notes on Some of the Insects of the Year in the State of New York. E. P. Felt . -

The Brown-tail Moth (Euproctis chrysorrhoa)............. C. H. Fernald..

The Distribution of the San Jose or Pernicious Scale in New Jersey .J. B. Smith..

Hydrocyanic Acid Gas as a Remedy for the San Jose Scale and Other Insects......................................W. G. Johnson ..

Some Notes on Observations in West Virginia............. A. Dopkins..

Notes on House Flies and Mosquitoes .................... L. O. Howard..

Pulvinaria acericola (W. \& R.) and P. innumerabilis Rathv. (illustrated) .............................................. O. Hovard..

An Abnormal Coccinellid................................ F. Burgess . .

Notes on Some Massachusetts Coccidæ....................R. A. Cooley..

Notes on Spruce Bark-beetles.............. M. Weed and W. F. Fiske..

Experiments with Insecticides for the Gipsy Moth and Brown-tail Moth*

Notes on the Life History of the Woolly Aphis of Apple (Schizoneura lanigera Haussinan) ........................................ W. B. Alwood..

On the Life History of Protoparce carolina............... I. B. Alwood..

Notes on the Fertilization of Muskmelons by Insects........F. W. Rane..

Notes on Tent Caterpillars................................... Weed..

Recent Work of the Gipsy-Moth Committee..............E. H. Forbush..

The San Jose Scale in Connecticut $\dagger$ (map) ............... W. E. Britton..

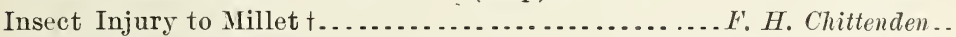

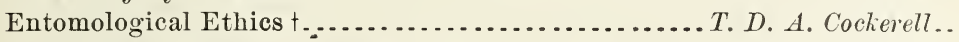

Vernacular Names of Insects t.......................... W. Doran..

Notes from Maryland on the Principal Injurious Insects of the Year $\dagger$ ............................................W. G. Johnson..

On the Life History of Thrips tritici *................. A. L. Quaintance..

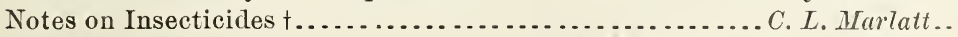

Insects of the Year in Ohio t............F. M. Webster and C. T. Mally.. 



\section{TENTH ANNUAL IEETING OF THE ASSOCIATION OF ECONOMIC ENTOMOLOGISTS.}

MORNING SESSION, FRIDAY, AUGUST 19, 1898.

The association was convened in the lecture hall of the building of the Society of Natural History, corner of Berkeley and Boylston streets, Boston, Mass., August 19, 1898.

The following officers and members were present:

Officers.-President, Herbert Usborn; secretary, C. L. Marlatt.

Members.-W. B. Alwood, C. J. S. Bethune, W. B. Barrows, W. E. Britton, A. F. Burgess, R. A. Cooley, H. G. Dyar, E. P. Felt, C. H. Fernald, H. T. Fernald, W. F. Fiske, E. H. Forbush, H. L. Frost, A. D. Hopkins, L. O. Howard, G. H. Hudson, W. G. Johnson, G. B. King, A H. Kirkland, G. H. Perkins, F. W. Rane, J. B. Smith, F. J. Smith, and C. M. Weed.

The presence of other persons not members of the association gave an average attendance of thirty to the sessions.

In the temporary absence of the president, Mr. C. H. Fernald was called to the chair, and some routine business was transacted, including a report from the committee on popular names of insects, the financial statement of the secretary, and the presentation of the names of candidates for membership. Under the latter head the following persons were elected to membership in the association:

Active members.-Elward M. Ehrhorn, Mountainview, Cal., horticultural commissioner of Santa Clara County, proposed by C. L. Marlatt and L. O. Howard; W. M. Scott, Atlanta, Ga., State entomologist, proposed by W. B. Alwood; W. F. Fiske, Durham, N. H., assistant entomologist, proposed by C. M. Weed; J. L. Phillips, Blacksburg, Va., assistant entomologist, proposed by W. B. Alwood; H. T. Fernald, Harrisburg, Pa., State zoologist, proposed by L. O. Howard; E. Dwight Sanderson and Franklin Sherman, jr., College Station, Md., assistant entomologists, proposed by W. G. Johnson.

On motion of Mr. J. B. Smith, a joint meeting was arranged for the morning of August 20 with the Society for the Promotion of Agricultural Science, for the reading of papers on entomological subjects only. A programme committee, consisting of the secretary and Messrs. Smith ancl Alwood, was appointed.

A recess of a few minutes was taken, after which, the president, Mr. Osborn, having arrived, the presidential address was delivered. 


\section{THE DUTY OF ECONOMIC ENTOMOLOGY.}

By Herbert Osborn, Columbus, Orio.

When I learned some months ago that this society had honored me with the presidency, there came to me, along with a sense of gratification that so high an honor from a society whose history and mission is so lofty, the sense of a difficult duty to perform. Our constitution requires, and custom has established, that each presiding officer shall present an address, and history has shown that each in his turn has brought to us of his choicest treasure, and our records include a continual series of notable contributions.

With such a duty in view, it was natural to cast about for some suitable theme, to try to marshal some group of topies that would be a fitting basis for the address on this occasion. There came to my mind then some features of our work and of our relation to the public that seemed to offer suitable material, but hardly had this line of thought presented itself than the appearance of the report of our previous meeting and the reading of last year's address showed me that much of what had occurred to me, and more that had not, was included in the address of my predecessor. While a substantial proof of the propriety of my line of thought, this naturally changed the situation for me and necessitated a review of the entomological horizon.

At our first annual meeting our lamented Riley presented an exhaustive discussion of the resources of entomology and the methods, equipment, and policy involved in such work, a paper to be read by every man aspiring to enter the profession.

Next, our genial Dr. Fletcher, from across the border, gave us a magnificent survey of the economic results already achieved by the studies in this science-a most convincing argument for the value of economic entomology to mankind. At the succeeding meeting, presided over by Professor Lintner, this veteran in the ranks found himself unable, on account of ill health, to prepare the customary address; in its stead we listened to a review of the work of the year from the vice-president, Professor Forbes, and the succeerling year the same gentleman, so long identified with the entomology of Illinois, brought forward a critical survey of the entomological work of the year, with much of suggestive value for future work. In 1894 Dr. Howard's exhaustive survey of the official entomological work of the different countries, showing the advanced position of American entomology, was not only a source of national pride, but a means of stimulating more effective work upon the part of all engaged in official entomological investigation. The interesting survey of European entomological work by Marchal, which supplements this in detail for the countries of Europe. has particular interest for those who care to compare the entomological work of the different parts of the world.

Professor Smith's interesting discussion of measures in 1895 was followed in 1896 by Professor Feruald's scholarly essay upon the evolution 
of economic entomology, a paper stored with most valuable historical data and rich in illustrations of methods for different periods of history. Last year Professor Webster furnished us an address full of thoughtful suggestion as to the problems that confront the entomologist of to-day.

The entomologist of the present bears a very different relation to the public than he did a quarter of a century ago. New knowledge and new responsibilities have come to him; whereas then his opinion was presented and received as a gratuitous matter to be experimented with if convenient, his dictum now carries the force of authority, and often has the support of State and Federal law. Instead of an entirely gratuitous service, he commands compensation, sometimes ridiculously meager, it is true, but nevertheless such as to obligate him to faithful performance. The economic entomologist, then, comes to his work as to a definite task; it must be to him not only a privilege, an opportunity, but a sacred and imperative duty, entailing special preparation and devotion.

What the range of this duty may be is perhaps open to discussion, certainly in its performance we have seen varied interpretations based on inclination, public demand, local necessities, but mainly a response to certain well-defined requirements. Some features of this question I propose to discuss with you here, and may announce my theme as "The duty of economic entomology." We will doubtless all agree to the proposition that the end and aim of our science is to enable the public in general to contend intelligently with the numerous insects that inter. fere with their well being. The essential work to accomplish this end is, however, open to discussion. It seems to me that its accomplishment must rest on several quite distinct lines of effort:

(1) Acquisition of knowledge of life and habits and direct remedies.

(2) A knowledge of distribution and methods of prevention or control.

(3) Education of people to appreciation of this need and to intelligent methods of application.

DUTY IN INVESTIGATION.

Most obviously the first duty of the entomologist is the acquisition of new knowledge. Wherever situated, it is not enough that he should simply restate for the benefit of his constitueney the facts that have been gathered in the past. New problems are constantly arising and eảch locality has, from the conditions pertaining to it, special problems for study.

In lines of investigation, however, there is much room for choice, and with a multitude of problems presenting themselves, one of the first and most important duties is the selection of the proper subject or subjects for study. Here a knowledge of what has been done, both locally and generaliy, becomes most essential, and no more profitable time can be spent than that given to reviewing the available knowledge.

While certainly such selection should be made as promises valuable economic results to the particular territory covered, I firmly believe that 
we each have a duty to general biology, which furnishes the basis for all economic work, and that while we choose subjects of immediate economic importance, we should not neglect such underlying problems as shall perfect the fundamental knowledge of our science. Much of the work done must necessarily be for immediate results, to derise ways and means for control of pests that are demanding notice from the cultirator, but as we build upon the work of the past, so we must contribute our share to the foundation for the future edifice.

It is hardly necessary here to call attention to the importance of lifehistory work as the essential basis for economic entomology, and if it were. I could refer you to the plea for such study so ably presented by my predecessors. It should not be forgotten, however, that this means more than the "mere breeding of the different stages of an insect, for beyoud them and dependent upon them are many deeper biological problems, the importance of which in economic work we can probably only slightly appreciate at the present time. The general problems of heredity, variation, dimorphism, mimicry, parasitism, influence of enviroument, distribution, etc., may seem at first to belong only to pure science, but I beliere a closer examination will show that in these and other fundamental questions we hare some problems of the utmost significance in the application of science to economy, and that from simple duty we should contribute such facts as we can toward their elucidation.

It has been the fashion to think that the solution of such questions is most easily sought amoug the simpler forms of marine life, but many fruitful fields are certainly still open for the student of insect life. Problems of distribution are of fundamental importance and can not be too thoroughly studied, eren though the immediate economic returns seem slight. Undoubtedly there are fundamental factors affecting the distribution of insects which, when fully known. will be of immense value in determining methods of control, necessities of quarantine, etc. While certain species of insects appear to orerride all barriers, I believe we will find that in the main they are dependent on certain conditions of climate and food plant, and that their natural limitations may be defined with reasonable accuracy. The value of such definition in determination of crops is erident at a glance.

Determination of limits in food plant is another and closely related line in which accurate record and exteuded, though not necessarily contiunous, observation is essential. To know the limits of food plant for any species is to have a most powerful weapon of coutrol, as for instance in the treatment of corn-root worm.

Of great importance also is the recognition of alternations in food plant and habit, and careful determinations in this direction hare not only high scientific interest, but great economic ralue. The phorodon of hop and plum furnishes a striking example of the utility of such knowledge. 


\section{DUTY AS QUARANTINE OFFICERS.}

One of the most important phases of economic entomology has but recently come to be appreciated. The distribution of insects and the means of their dispersal, while long since given study, has only lately taken its most positive economic form, but with the appreciation of the fact that insects are constantly being transported from country to country, and that in many cases their appearance in a new country marks a period of most rapid increase and extended destruction, makes it an imperative duty to devise means for preventing such distribution wherever possible. Whatever we may think as to the possibilities of suppression or the best means to accomplish exclusion, we can not but agree that such exclusion is the only safeguard against such pests. That the enactment of quarantine laws and adoption of systems of inspection will prove an absolute safeguard none dare contend, but until some surer method presents itself, or it can be shown that this entails more loss than gain, it deserves careful attention, the most painstaking adjustment of laws to conditions in various sections, and a cordial support from the rorking entomologists of the country.

The heroic effort made by this State of Massachusetts to exterminate the gipsy moth is one of the best and most effective arguments for a system of exclusion, the cost of which would be slight compared with the loss entailed by an imported pest. This gigantic effort is but partially understood or appreciated even by entomologists, and I count it one of the great opportunities of this meeting that we may each see for himself the methods'employed and results obtained in this undertaking, the equal of which is not to be found recorded in history.

Dr. Howard gires most emphatic testimony as to the propriety of undertaking suppression, and also that the money appropriated for the purpose has been used in the best possible known method to accomplish the desired result. I beg to suggest in this connection that when we may have secured a general consensus of opinion on such questions, we should each strive to give individual support to it. By raising objections we tend to obstruct our science, and unless some vital principle is at stake, we may far better not permit such division of opinion to go before the public. Diversity of view is one of the essentials of progress, but let us have expression of such diversity among ourselves, and so far as possible stand together in final recommendation to the public.

There creps out at times an indication of a sad lack of appreciation on the part of scientific men of the aims and results of economic work. That a reputable scientific journal should consent to such a slur upon the work of the Gipsy-moth Commission in Massachusetts as has recently appeared, shows either unfortunate jealousy or unreasonable prejudice against such effort. When the highest available authority has been definitely committed to a certain policy, there is certainly every reason why men of science in related lines should avoid such 
criticisms or contemptuous sneers as to prejudice the uninformed public against such policy. The general public is at best slow to adopt the results of science and inclined to be suspicious regarding even well-established points. What else can we expect, then, if some parties in the name of science denounce such results but that scientific work in general shall be discredited and its advancement hampered where it should be supported.

\section{DUTY AS EDUCATORS.}

The problem of how to reach with the facts we have gathered the people for whom we work, is one of the most difficult to solve. It seems to me to be so closely connected with our schemes of education that I venture to make some suggestions upon it here.

No matter how carefully we experiment, how accurate and useful our results, we must place these results before a public uneducated in the details of our science-indeed, a public the majority of which have scarcely the first elements of a knowiedge which will permit them to use the results presented. This means that we must present explicit instructions as to method, leaving nothing to the reader, and that he must follow in the most empirical manner. How shall we remedy this difficulty? Teach entomology or zoology in the common schools? I certainly can not bring myself to advocate such a measure under present conditions. While I wonld not discourage any effort toward a wider knowledge of nature on the part of all school children, I must confess to considerable distrust of the fad for nature study as it is cropping out in later years, mainly because I fail to see where suitably prepared teachers are arailable to conduct such work. Not one common school teacher in a thousand, I think it safe to say, is prepared to take a child and give it instruction in this line. To attempt it with teachers totally unacquainted with nature is simply to foredoom to failure. Education here, as in other lines, must go from the higher to the lower grades. The universities must and are preparing a corps of teachers who are becoming more and more proficient. These in turn in the smaller colleges, academies, and high schools will gradually bring some scientific method and system to the teaching of biology, and in time, I trust, the subject may be taught in something like suitable form to interest and instruct the young pupil. The method, however, has been much discussed, and we have at present widely varying policies advocated by distinguished educators. I think we may reasonably inquire whether the present trend of university training in zoology is the best possible for the end we have in view.

The success of economic entomology among the people in general is dependent on their ability to use the knowledge gained by experiment, and this ability is dependent on the training received in lower grades of school work, the teaching of which must come from higher institutions of learning. Our success as economic entomologists, then, is vitally interested in the methods of instruction employed in the higher 
schools. We can not absolve ourselves from an interest or a duty in this direction even if $\mathrm{we}$ would.

From an extreme of systematic zoology, which consisted largely of memorizing scientific names of species and groups, we have gone to an extreme in histology and morphology, which in some cases almostignores the recognition of species or the relationships of the organisms studied.

The refinements of modern technique in sectioning, etc., while of great value in furnishing knowledge in domains hitherto unexplored, have carried some of the votaries of microtomy to the point of having only contempt for other phases of biological science. While of utmost value in the science and worthy most extended utilization in the training of the zoological student, such technique should not be made the end of zoological study. Rather, it seems to me, this work should be viewed as a most important aid in the determination of phylogenies, the establishment of fundamentals in the recognition of relationships.

From the standpoint of the general student, and especially from our own view point, which has in sight the man in ordinary life, there is an important factor here-the attractiveness of the subject. Experience shows that young students are far more likely to be attracted by the comparison of various species, the forming of collections, which involve more or 'ess of systematic work, and we certainly may legitimately use this fact in planing lines of study for general students. To show coutempt for such part of zoo'ogical work seems to me quite inexcusable. Indeed, some of our best zoologists seem to be reaching the conclusion that to put a student too early upon pure morphology and histology is quite likely to discourage him and quench his natural enthusiasm for nature study. It is certainly unscientific and likely to lead to serious error to conduct laboratory work with half a dozen species, probably of different genera, of grasshoppers and allow the student to label them all, after the guide, Acridium americanum. Exactness here is just as essential as in the determination of how many thousandths of a millimeter a section is in thickness.

It appears to me that properly used there is one of the most fruitful fields of study for us as investigators, and for subject-matter for instruction, in the tracing of phylogenies. This implies from the very first a morphologic basis for all systematic work, a most rigid application of all the results of modern histology and embryology, the nearest possible approach to the actual lines of descent and consequent relationship of the groups considered. No matter how small or how large the group in hand, the effort should be to leave it with a better recognition of the characters having phylogenetic significance. With elementary students such matter must of course take the form of noting similarities of structure rather than technical discussion of relationship, but the one learls to the other, and a student familiar with the comparative method of study will later readily grasp the fundamentals of relationship.

We sometimes hear the statement that the old-time naturalist is passing away, and in this age, when every profession becomes so specialized 
that each worker must be an expert, there is perhaps little opportunity for the cultivation of entomology as a pastime. But the old-time spirit should not be allowed to decay. The spontaneity and enthusiasm, the close tonch with life where life abounds, are factcrs of greatest value to the worker who wishes to get the utmost fromi his exertions.

Briefly, the year has been characterized by active work in entomological lines. Numerous valuable papers have appeared from the Division of Entomology of the U. S. Department of A griculture, from the offices of State entomologists, and from various stations workers. These contributions are too numerous to review in detail, and with so many of value, to select for special mention is impossible. In several States insect legislation has been enacted mainly with reference to the San Jose scale, and active efforts are being made to prevent the distribution of this pest.

The appearance of Dr. Packard's text-book on morphology of insects is a welcome addition in a line but poorly represented heretofore in American entomological literature.

Our hearts are saddened by the thought that two of our most distinguished and devoted members have been called from our midst: Đr. D. S. Kellicott, whose death in the prime of life removes a most earnest and effective worker. Dr. J. A. Lintner, whose ripe experience and extensive contributions to entomology have made him for many years the most welcome and revered of all the members who have annually attended these meetings. I would suggest the propriety of a committee to prepare a memorial for our next report.

In looking to the future of our association, we can perhaps recognize more fully its international character and encourage in every way possible the cooperation of foreign members. As constituted, we have no political boundaries, and geographical boundaries for convenience only, and we should strive to extend the activity of our organization. This has a practical importance, for with the greater attention to the transmission of injurious insects from country to country the cooperation of foreign entomologists will become more and more important, and I know no more natural channel for such cooperation than an organization such as we have here.

That we hare much reason to feel gratified with the record of our association during its brief career need hardly be said; that we have before us interesting and important work for this session is plainly shown by the programme arranged by our energetic secretary; that we shall all go from this meeting with renewed zeal, higher ideals of work, and closer ties of friendship for our fellow workers, a waits only time for realization, and I propose that without further delay we proceerl to the important work we have before us.

On motion of Mr. Barrows, seconded by Mr. Howard, the thanks of the association were tendered the president for the excellent address presented. 
On motion of Mr. Smith, a committee, consisting of Messrs. Smith, Howard, and Fernald, was appointed by the president to prepare appropriate resolutions relative to the loss sustained by the association by the deaths of Dr. J. A. Lintner, of Albany, N. Y., and of Dr. David S. Kellicott, of Columbus, Ohio.

The resolutions subsequently submitted are as follows:

Whereas the deaths of Dr. J. A. Lintner, of Albany, N.Y., and Dr. David S. Kellicott, of Columbus, Ohio, which occurred since our last meeting, have been grievous losses to entomological science and to our association; be it

Resolved by the Association of Economic Entomologists, That we hereby express our deep sense of grief at this our loss, and our profound appreciation of the sterling qualities of mind and heart which endeared our former companions to us and gave them their eminent standing in science.

Resolved, That a copy of these resolutions be transmitted by the secretary to the personal representatives of the deceased.

The reading of papers was then taken up, Mr. Howard presenting a communication under the following title:

\section{TWO BENEFICIAL INSECTS INTRODUCED FROM EUROPE.}

By L. O. Howard, Washington, D. C.

\section{(a) AN INTENTIONAL IN'TRODUCTION.}

In the autumn of 1895 the writer received through the courtesy of Dr. A. Berlese, of the Stazione di Entomologia Agraria at Portici, Italy, specimens of a remarkable Chalcidid, which, after study, was recognized as Aspidocoris cyaneus Costa, a species described by the Italian writer in 1563 from specimens discovered in Italy. Later it was discovered that this insect was synonymous with Scutellista cyanea, described by Motschulsky in 1859 from specimens reared by Nietner in Ceylon from Lecanium coffect. Dr. Berlese had reared these specimens from the common European Ceroplastes rusci, and it immediately occurred to the writer that this insect would be a valuable one to introduce into this country, owing to its numbers in Italy and on account of the fact that in Florida and other Southern States Ceroplastes floridensis is an abundant and injurious scale.

In a paper published in the Rivista di Patologia Vegetale in 1896 the writer figured the species, which is one of very remarkable form, and redescribed both sexes. In correspondence with Dr. Berlese and his colleague, Dr. Leonardi, he has since repeatedly urged the sending of living specimens of this insect to the United States, and has met with much courtesy from both of these gentlemen, who have on several occasions taken the trouble to collect and send branches carrying Ceroplastes infested by this interesting parasite.

None of the experiments have been successful until the present year. Early in June a package was received from Dr. Leonardi containing: twigs well incrusted with the wax scale, and these were put aside in a breeding jar to observe the outcome. On the second day after arrival 
there issued from the scales several specimens of a species of Tetrastichus. This was eminently discouraging for the reason that all of the species of this genus are hyperparasites, and it seemed possible that the Scutellista had been killed off by this smaller Chalcidid. No further specimens of Tetrastichus, however, emerged, and several days later the breeding jar, when examined in the morning, was found to contain many active specimens of both sexes of the Scutellista.

In the meantime arrangements had been made, both at Washington, D. C., and at Baton Rouge, La., to endeavor to establish the species. Prof. H. A. Morgan had for several years held himself in readiness to attempt the experiment, since at Baton Rouge are several trees badly affected by the Ceroplastes. In the insectary at Washington City a large potted plant had also been stocked for two or three years with this scale. Living specimens found in the breeding jar were immediately transferred to the last-mentioned tree and kept there under a gauze cover. The twigs and all of the contained parasites were carefully packed and transmitted to Baton Rouge, where, in the absence of Professor Morgan, they were cared for by Prof. S. E. McClendon. At Washington the Scutellista remained alive for many days under the gauze cover on the potted plant. They crawled over the Ceroplastes and endeavored to oviposit. Whether they were successful or not, it is as yet too early to learn. Professor McClendon, under date of July 2, has written that the box containing parasites was received in good condition and the twigs were immediately fastened to a tree badly affected with the Ceroplastes. A number of the parasites had issued in the box on the journey, and they were let loose upon the tree, and could be seen ten minutes afterwards crawling very actively around over the scales. The tree upon which they were placed is surrounded by a number of others, all badly affected with Ceroplastes, so that without any further precautions it is altogether likely that the species will become established at Baton Rouge.

This is one of the comparatively simple introductions which can readily be made with many of these internal feeding parasites. The writer first called attention to the ease with which this sort of work can be done in his article on "Parasites of the Coccidre" in the Annual Report of the Department of Agriculture for 1880.

\section{b) AN ACCIDENTAL INTRODUCTION.}

In 1880 Professor Comstock called attention to the occurrence of the European Asterodiaspis quercicola (Bouché) upon imported European vaks on the grounds of the United States Department of Agriculture at Washington, D. C. This species, he stated in his report as Entomologist for the Department of Agriculture for that year, is not a common one in Europe, but is occasionally destructive to an individual tree. Like so many other European insects, however, when once imported into the United States, this species has become abundant and destructive. One large tree upon the grounds of the Department of A griculture at Washington has been killed ontright. 
Since its discovery in the District of Columbia it has been found in many other parts of the country, and has evidentally been brought over from Europe a number of times on independent importations of European oaks. In America it does not confine itself to the imported species, but soon becomes established on native species, and spreads with more or less rapidity and multiplies very greatly.

There is a most interesting Chalcidid which occurs in Europe, and which was described in 1837 by Westwood as Encyrtus dalmanni. This parasite was subsequently placed in Fœrster's genus Habrolepis by Gustav Mayr in his revision of the Encyrtine of Europe. It is structurally a very remarkable form, and is one of the most beautiful species of the interesting group to which it belongs. It has been reared in Europe at different times by Tschek, Schlechtendal, and Reinhard from an undetermined coceid upon Quercus pubescens and Quercus pedun-

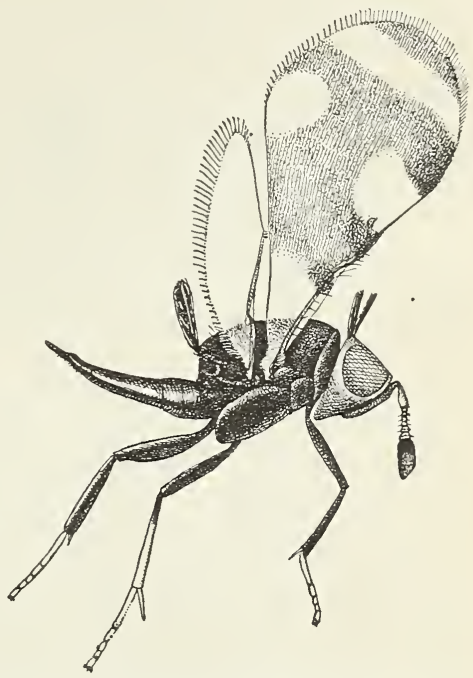

FIG. 1.-Habrolepis dalmanni; side view of female-very greatly enlarged (original).

culata. Giraud also reared it from a coccid upon oak which he believed to be Bouché's Aspidiotus quercicola, which was afterwards placed by Signoret in his genus Asterodiaspis, and it becomes probable that the unnamed hosts from which it was reared by the other authors mentioned

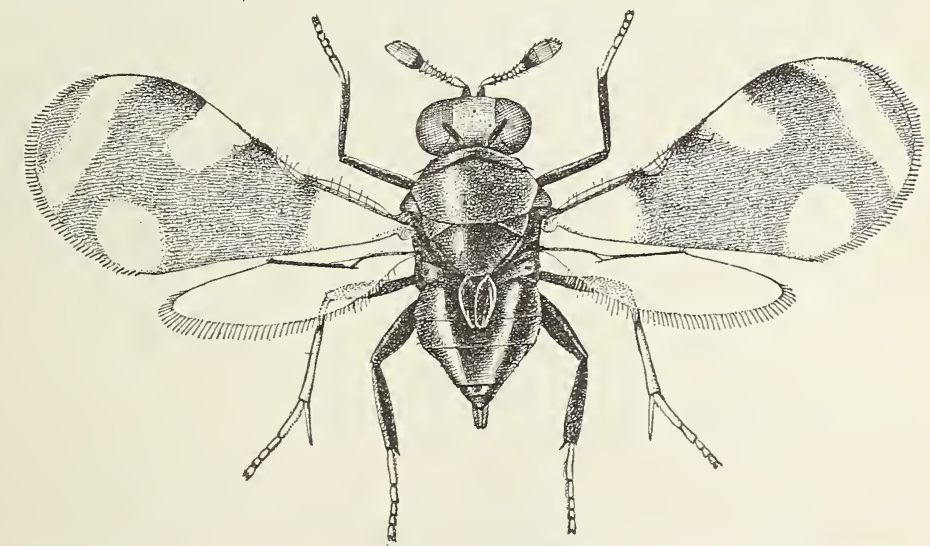

Fig. 2.-Habrolepis dalmanni; dorsal view of female-very greatly enlarged (original).

were all this species; in fact, we can say with a reasonable degree of probability that the European host of Habrolepis dalmanni is Asterodiaspis quercicola (Bouché).

The writer had never seen this beautiful Chalcidid (figs. 1 and 2), except in a single example sent some years ago by Dr. Mayr, until June 
of the present year, when he was surprised and delighted to receive a large series of specimens from Mr. A. H. Kirkland, who had reared the species from Asterodiaspis quercicola, which he states has become common upon the oaks throughout the Middlesex Fells in the region near Boston. It must be many years since this scale insect became originally established by means of imported trees near Boston, since it has spread so greatly and established itself so thoroughly, and it is more than likely that the Habrolepis was brought over in small numbers with the original importation. That the scale insect, in spite of the presence of this parasite, has spread and increased so remarkably is by no means an indication that eventually the parasite may not become very abundant and exercise a restrictive influence upon the further spread of the scale; in fact, we should rather expect that there may at some time come a season when the parasite will become enormously multiplied and seriously retard the increase of its host.

The writer has already called attention to the ease with which these internal parasites of the Coccidæe are distributed by means of the commercial distribution of their hosts, and has shown that many of the species of Aphelinina have already become subcosmopolitan in this way. A similar commercial distribution of the insects of the subfamily Encyrtinæ has not as yet become so marked, yet such a distribution must constantly be going on, and this instance is a good example of what we may expect with this group as well as with the Aphelininæ.

The extraordinary structure of the Habrolepis dalmanni has been incidentally mentioned. It is in fact a unique type among the European Encyrtinæ, and although it was described more than sixty years ago from Europe, the writer has always suspected from its oriental facies that it was originally an importation into Europe. Recent receipt of specimens from $\mathrm{Mr}$. Koebele has confirmed him in the idea that Habrolepis is an oriental type. Undescribed species from Japan indicate this fact. It is worthy of remark, however, that other specimens have been received from Mexico. These may be descendants from specimens imported from Japan to Mexico, or the genus may also be neotropical.

The paper was briefly discussed by Mr. Alwood.

Mr. Felt presented the following paper:

\section{NOTES ON SOME OF THE INSECTS OF THE YEAR IN THE STATE OF NEW YORK.}

By E. P. Felt, Albany, N. $Y$.

The present season has been characterized by the scarcity of plant lice, only one or two complaints having been received, whereas in 1897 reports of injuries by these insects came from all quarters. The foliage 
of the forest and shade trees appears to have suffered more than usual. In Albany, and other cities and towns in the State, the white marked tussock moth, Notolophus leucostigma Sm.-Abb., and the elm leaf-beetle, Galerucella luteola Miiller, have been more injurious than "usual. In the rural districts the tent caterpillars have wrought havoc in orchard and forest.

Eriocampoides limacina Retz.-The cherry or pear tree slug causes more or less injury from year to year in New York State; especially is this true in nurseries. During the inspection of nurseries last antumn indications of its presence on pear trees were the rule, and in some cases the foliage had been materially injured. Last June Thomas Tupper, of Corning, N. Y., reported serious injury by this insect to both his cherry and pear trees.

Byturus unicolor Say.-The latter part of May Dr. Peck, the State botanist, brought me several beetles belonging to this species, with the statement that from one to five were to be found in many of the opening buds of his raspberry plants, where they were evidently feeding. This insect does not appear to hare been noticed in the State since Dr. Fitch gave a brief account of it in his fourteenth report for the year 1870, although Dr. Lintner records in his eighth report for the year 1891 its receipt from New Haven, Conn., where it had been injuring leaves and buds of the raspberry.

Elaphidion villosum Fabr.-Complaints of injuries by the oak or maple tree pruner have come from several localities the present season. Serious injuries were reported from Lake George and also from Oakes, Ulster County, where its operations had been observed for several years past.

Galerucella luteola Mïller.-The prolificacy of the imported elm leafbeetle was brought very forcibly before me by certain studies made in connection with the preparation of Bulletin 20 of the New York State Museum. The last day of May I captured two beetles, well distended with eggs, and determined to ascertain for myself the number they would produce. One was confined in a small, corked vial and the other in a jelly tumbler. As might be expected, there was considerable difference in the number of eggs deposited, the former producing 431 and the latter 623. A portion of the discrepancy was probably due to disparity of conditions and the remainder must be attributed to a variation in capacity. In order to bring certain points out clearly, I have tabulated the record.

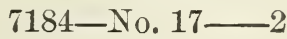


Record of eggs deposited by two elm leaf-beetles.

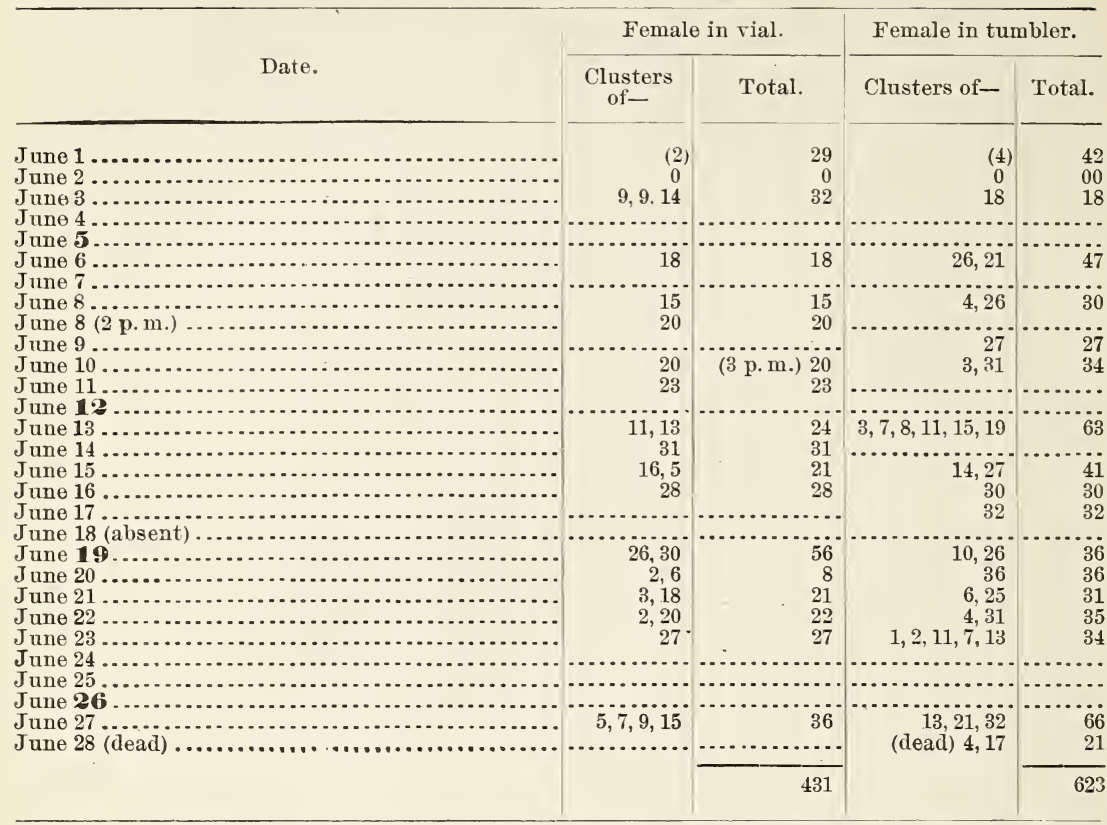

* The examinations were made, as a rule, between 8.30 and 9 a. m., although occasionally when eggs were seen in the afternoon they were recorded and the time indicated as in the table. The dates falling on Sunday are in bold-face type, and as a rule no observations were made then.

It will be seen that from June 1 to 11 there were usually deposited between 15 and 47 eggs every other day. The 12th, being Sunday, I did not attend to the beetles, but from there being two or more clusters found with each on Monday it is probable that one or more were deposited the preceding day. The record shows that from either the 12 th or 13 th there was a marked increase in the number of eggs laid from then until the $23 d$, there being as a rule from 8 to 40 deposited daily. In the case of the one confined in the vial the record shows a discrepancy which is greater than the facts warrant. I was unable to attend to the insects on the 18th. Consequently it appears as though two days during this period had been skipped by one beetle, and one by the other, whereas it is probable that but a day passed without the beetle in the vial depositing eggs and that the other really presents an unbroken record in this respect. During this short period of ten or eleven days there were deposited over half of the total number of eggs produced during the twenty-eight days a record was kept, the figures being 238 and 338, or an average of over 21 and 30 eggs per day, respectively. The average numbers deposited during the first eleven days of the month are 14 and 18 , respectively, which shows there was an increase of one-half or more in the case of each beetle after June 11. Those deposited after the 25th were apparently the last efforts of the 
insects to provide for the perpetuity of their kind. although the quality of the eggs had not deteriorated.

During the whole period the beetles were under observation they consumed large quantities of foliage, comparatively speaking. Many of the trees outside were also badly riddled by the feeding. If we consider for a moment the relatively large bulk of eggs pruduced by the beetles it is not surprising that they require a large amount of food. Without attempting to make precise measurements it would seem that a cluster of 30 eggs would present, after leposition, a bulk about equal to that of the parent insect. If this be a fair estimate, they produced on the arerage from nearly one-half to nearly two-thirds of their bulk in eggs daily during the first eleven days in June, and from the 12th to the 23d the daily average was from over two-thirds to an equal bulk. This rapid elaboration of eggs must make a large demand upon the system and require an abundant food supply.

Lest it be thought that the period of oviposition was abnormally prolonged, I would state that recently deposited eggs were to be fund on the trees up to July 9. This record indicates most emphatically the value of spraying to kill the beetles, especially before they have reached the more prolific period mentioned abore.

A few notes confirmatory of previous records concerning the life history of this insect in Albany and Troy wiil undoubtedly be of interest. The last of the over-wintered beetles were seen early in July. On the 16th recently transformed adults were easily found, and fresh eggs a few days later, either singly or in small clusters, indicated the beginning of oviposition by the second brood. On the 12th of August Mr. P. C. Leiris, who has charge of the spraying in Albany, informed me that the second brood of larva had been quite injurious in certain parts of the city, and that the beetles, ever on the watch for tender foliage, riddled the leaves very quickly. A visit to Troy on the 13th showed that practically the same conditions prevailed there. Soon after the foliage appeared it was attacked by the beetles, and by the time the leaves were about half grown many larva were to be found upon them. The injury to the elms in Troy by the first brood of larve exceeded that of the preceding two years, because it was not only much more extended but the skeletonizing of the leaves was more thorough. As a rule all the Eurnpean elms were practically defoliated. The same would have been true of Albany were it not for the spraying done by the city. An interesting feature in the latter city was the more extended injury sustained by the American elms. In Troy comparatively few of this species appear to have suffered much. The same was true of Albany two year's ago. Last year considerable injury was inflicted, and the present season much more, in spite of the spraying. It slıould be stated that rainy weather. just after the larve hatched, marred the efficiency of the work seriously. A few of the American elms in Albany have lost nearly every leaf, and hundreds have been so affected that 
they present a more or less browned appearance. In Watervliet, where American elms abound, the ravages have been frightful, including practically all the elms.

Galerucella caricollis Lec.-In his eleventh report. Dr. Lintner noticed this insect briefly and gave its eariier history. 'The species is one that is apparently changing its habits and becoming destructive. Mr. Tupper, of Corning, N. Y., submitted examples of this insect and leaves from his cherry trees, with the statement that they were injuring the trees seriously and might kill them. This is the second record of a recent attack on cherry in New York State by this species.

Notolophus leucostigma Sm.-Abb.-The larve of this species were unusually destructive in Albany this season. Not only were a large number of horse chestnuts defoliated, as frequently occurs from year to year, but many of the maples and lindens were serionsly injured. On some trees the caterpillars were so abundant as to cause an unpleasant odor. It appears nearly impossible to secure adequate protection for trees along the streets, unless it is undertaken by the municipal authorities. The private individual who inquires what lie should do to protect his trees after two-thirds of the foliage is destroyed usually neglects to take proper precautions to prevent trouble another season. The injuries by this species in Buffalo have been so general as to excite considerable attention from the public, and have led to the issuing of a special circular by the board of public works, giving directions for controlling the insect. It was also reported as very abundant at Flushing, Long Island.

Ravages by tent caterpillars.-In early spring a number of reports came to me of the extraordinary abundance and destructiveness of the apple-tree tent caterpillar, Clisiocampa americana Harr. In many localities the larvæ stripped the trees and nearly covered the naked limbs with their webs. Such work was clearly the result of neglect, and yet Dr. S. D. Willard, of Geneva, who cares for his trees each year, informed me that this insect caused him considerable trouble last spring, notwithstanding his efforts to keep it under control. Last year the so-called forest tent caterpillar, Clisiocampa disstria Hiibn., was very injurious in certain parts of the State, stripping the foliage from hundreds of acres of maples and other trees in Delaware County and in other portions of the State. It was hoped that the ravages by this species would not be repeated the present season, but such was not the case. Examples of this caterpillar were received from Glen Falls, N. Y., on June 2, with the statement that they were very numerous and injuring the maples seriously. At Trenton Falls, N. Y., the caterpillars were very abundant and injurious in the woods, although the trees were only partially defoliated. At Russell, St. Lawrence County, the leaves were stripped from 125 acres of maple trees, most probably by this species. It was also reported to me as very injurious this year in Otsego, Delaware, and Greene counties. 
Mamestra picta Harr.-A remarkable abundance of larvæ in timothy hay was brought to my notice on July 13. Mr. W. C. Browning, of Alexandria Bay, stated that he had been putting in hay from a 20 -acre lot, and the next morning found the surface of the mow literally alive with caterpillars-identified from examples sent as those of this species. Large numbers must have been present in the field, as they had probably been gathered up with the hay accidently. In response to an inquiry, Mr. Browning informed me that the caterpillars had not been observed except on this field. Last year they had entirely destroyed his crop of oats, and this season they were much more numerous than before.

Xylina laticinerea or $X$. cinerea.-One of the most interesting and remarkable outbreaks of the year occurred at Schenectady, N. Y., when hundreds of silver maples were defoliated by the caterpillars belonging to one of the species named above. My attention was called to the insect by a young man bringing me about half a pint of larvæ with a story of their destructiveness. On visiting the city it was found that the reports were true. The soft maples were practically stripped. Numerous larvæ were seen on the trunks, in some cases 50 to 100 on a single tree. Many were seen along the walks and in the roadways bordered by the maples. Even were one deprived of sight, the olfactory organs could easily detect their presence from the peculiar odor emanating from the hosts of eaterpillars. There were no indications of the insects' work in Albany, although only 17 miles distant, but along the Mohawk River, as far west as, Herkimer, on the Raquette River in St. Lawrence County, and in Schoharie County, many soft maples were defoliated, indicating the work of the same insect, possibly, although the species could not be determined because no examples were submitted. The ravages in some of these localities may have been caused by the forest tent caterpillar, Olisiocampa disstria Hiibn.

I have found no record of serious injury to maples by this species, although Dr. H. G. Dyar, in a recent letter identifying the insect, informs me that it is somewhat injurious to soft maples at Bellport, Long Island, but that they were less common than usual the present season. This insect, or a closely allied species, has been known for a number of years as injurious to apples and pears, and in 1896 and 1897 it caused considerable damage in this state to these fruits, but this appears to be the first record of serious injury to soft maples by a species of Xylina.

An elm leaf-miner.-This insect has been unusually destructive in Albany and Troy the present season. For the past three years the Camperdown elms in Washington Park, Albany, have suffered rather sererely from this species. The present season the insect not only seriously injured the Camperdown elms, but extended its ravages to the English, Scotch, and American species. From half to two-thirds of the leaves on certain Euglish elms in Troy were nearly destroyed by 
this insect, and many others presented a sorry appearance on account of the numerous mines.

Pulvinaria innumerabilis Rathv.-This destructive scale insect is being constantly brought to notice here and there in the State, although during the past few years it appears to have been less destructive than usual. On July 5 this scale was reported as injuring the elms seriously at Sandy Hill, N. Y., and affecting the maples to a less extent. At that time the young had not left the protecting filaments of the mother, although they were numerous in the cottony secretion. A few days later, twigs of maple were received from Baldwin, Long Island, their condition revealing a very serious attack. One side of each twig was nearly covered by the adults, while the young fairly swarmed over everything. I have also received twigs badly infested with this scale from Batavia and Flushing, N. I., and Arlington, X. J.

Lecanium armeniacum Craw.-One of the interesting features of the year was the detection of this scale (identified by Mr. Pergande), in Erie County, N. Y. In response to inquiry about its introduction, Mr. Hayes stated that he could not account for it in any manner. The vine upon which the species was found had been planted ten years. His neighbors had not set out any Californian stock, and he had used no fruit from that State for several years. A possible source of introduction is the sending to this State in 1896 of examples of this scale infested with Comys fusca, by Mrr. Ed. M. Ehrhorn, horticultural commissioner of Santa Clara County, Cal. This was done, it was stated, in the hope that the parasite would attack the New York plum scale.

Lecanium cerasifex Fitch.-This scale, identified as probably this species by Mr. Coquillett, has been very injurious to several soft maples in Albany the past two or three years. The trees have been dwarfed by the attack and each summer are more or less blackened by the copious honeydew secreted by the insects. Many of the limbs are nearly covered with the scales on their under surface, and during a portion, at least, of July and early in August the young swarm over branches and leaves.

The San Jose Scale.-This pest, Aspidiotus perniciosus Comst., has demonstrated its ability to thrive in the Hudson River Valley as far north as Albany, at least. Just across the river at East Greenbush, an infested fruit garden has been under my eye for over a year. The scale has spread in spite of the efforts of the owner, who used whaleoil soap to some extent. It has ruined many currant bushes and badly stunted a number of pear trees, besides infesting to a certain degree peach and apple trees. On the 9th of last July numerous young were to be found on the more tender shoots, some appearing as though dusted with pollen on account of the larvie clusterea at their tips. Develop. ing scales were found in small numbers on the leaves and abundantly on the fruit. At its present rate of multiplication, most of the young trees in that garden will he ruined in a few years. Only this spring I found the scale at Lebanon Springs, some 20 miles from the Hudson 
River, and at an elevation of 900 feet, $29^{\circ}$ below zero being known in that locality. Even when exposed to such extremes of temperature, and probably outside the limits of the Upper Austral life zone, the insect nad been able not only to hold its own, but had increased some, as the few trees infested were badly covered with the scale. It had spread very little, although the trees had been set out since 1895. This is evidently near the limit where climatic conditions are too severe to permit of its becoming a very injurious pest. The known distribution of this scale in the State is very interesting, since it has been found in localities here and there throughout most of the area lying within the limits of the Upper Austral life zone. It has been reported from localities in every county in the State east of the Hudson River, except Westchester and Washington, and from those on its west bank south of Warren County, except Greene and Rockland. The following are the localities: Rensselaer County, East Greenbush; Columbia County, Lebanon Springs, Kinderhook, and Germantown; Dutchess County, Poughkeepsie; Putnam County, Brewster; New York County, New York; Saratoga County, Burnt Hills; Albany County, Loudonville; Ulster County, Boiceville; Orange County, Middletown. Besides localities on Long Island, it has been found in Tompkins County, at Ithaca; in Seneca County, at Farmer, and in Cayuga County, at Union Springs.

In the discussion Mr. Smith stated that he was much interested in the records presented, because they indicated such remarkable differences in the habits of insects in neighboring States. Referring to the elm leaf-beetle, he stated that in New Jersey the insect was not present this year in sufficient numbers to make spraying necessary and that there was no notable injury; the same was also true of last year. The cottony cushion maple scale, on the contrary, was very abundant, always on maple. He referred also to the finding of Galerucella cavicollis on peach in Pennsylvania and the reported finding of Mamestra picta on oak and chestnut, questioning the accuracy of the latter observation and suggesting that some other larva had been mistaken for picta.

Mr. Cooley referred to the finding of the cottony maple scale on the English elm, American elm, and the Camperdown elm, but most abundantly on maple.

Mr. Howard said that many topics suggested by the paper might be discussed. He referred to the sending of a parasite of the plum Lecanium, Comys fusca, from California to New York through the agency of Mr. Ehrhorn, as being a case of carrying coals to Newcastle, since the species has long been known to occur in the East and in New York State.

Mr. Kirkland stated that it had been distinctly an elm leaf-beetle season in Massachusetts. He also referred to the fact that a green maple worm apparently identical in character and habits with the one 
described by Mr. Felt committed serious local damage in the vicinity of Boston this season. The injury was confined to the silver maple and the horse chestnut. The larve collected were parasitized and he had secured no imagos.

Mr. Osborn commented on the value of records similar to those given in the paper relating to periodicity and dates of occurrence of insects in different States, and the possibility after many such records having been accumulated of obtaining a correct understanding of the factors determining periodicity and the effect of temperature on times of appearance.

Professor Fernald presented the following paper:

\section{THE BROWN-TAIL MOTH.}

(Euproctis chrysorrhoa Linn.)

Bу C. H. Ferxald, Amherst, Mass.

The brown-tail moth is a native of Europe, occurring in all parts of that country except in the extreme north. It also occurs in Morroco, Algeria, and Asia Minor. In Great Britain it is apparently confined to the southeastern counties of England, though,as Mr. Barrett states, there is some reason to beliere that its range was formerly much wider than at present. There are two records of this insect having been taken in Scotland, and it has also been taken in Ireland, but this last is believed to be an error.

It is an interesting fact that this insect is becoming rare in parts of England where it was formerly common, and active measures are being taken by English entomologists to prerent the extinction of this and a few other species that appear to be doomed to the same fate. Various reasons have been given for the gradual extinction in England of the brown-tail moth, the gipsy moth, and sereral other species, but none of them, so far as I can judge, are under our control, and I do not feel entirely sure that the real cause of their extermination has as yet been discovered.

\section{NAJIES.}

This insect was first scientifically described and named Bombyx chrysorrhoea by Limneus in 1758 , but it has since been placed by different authors in other genera, as Euproctis, Liparis, and Porthesia. The oldest of these, the genus Euproctis established by Hiibner, has been adopted by many of our leading entomologists, and seems to be the most correct one to use. We have, therefore, adopted the scientific name Euproctis chrysorthoe Linn., and the common name, brown-tail moth, since this appears to be almost unirersally used in modern Erglish writings.

FOOD PLANTS IN EUROPE.

The brown-tail moth is reported in Europe as feeding on apple, pear, plum, oak, beech, elm, willow, mountain ash, blackthorn, Cotoneaster vulgaris, Sunguisorbis officinalis, and other plants. 


\section{REMEDIES IN EUROPE.}

The method of destroying this insect in Europe is to remove and burn the tents in which the young caterpillars hibernate. This is done during the winter months while the young caterpillars are in the tents.

\section{LAWS IN EUROPE.}

A law was enacted in France for the destruction of this insect as early as 1734 , but later it was extended so as to include the gipsy moth and some other injurious species common in Europe. Belgium and other European countries have also enacted similar laws requiring the destruction of these insects, and when the occupants of the premises neglect this work at the proper time, it is done under the direction of the authorities, and the expense is assessed on the owner or occupant of the land, and collected with his usual taxes.

\section{INTRODUCTION INTO AMERICA.}

The brown-tail moth was first reported in this country in Somerville, Mass., in the spring of 1897 , and careful inquiries revealed the fact that this pest had been observed by some of the residents of that locality for at least five years.

In the center of the infested region is a florist's establishment, where, previous to 1890 , roses and other shrubs were imported from France and Holland, and it seems very probable from all the facts obtained that the brown-tail moth was accidentally introduced on some of these plants as early, perhaps, as 1885 .

\section{DISTRIBUTION IN THIS COUNTRY.}

A somewhat superficial examination of the infested territory made soon after learning of the presence of this insect in Massachusetts showed that at that time it occurred in the greater part of Scmerville, a large part of Cambridge and Everett, a small part of Medford near the Somerville line, and a single colony was found in Malden near the Revere line. The area in which serious damage had been done by this insect at that time was nearly circular in outline, with its center near the junction of Vine street and Somerville avenue, in Somerville, with a diameter of about a mile.

The female as well as the male moths fly readily by night, but the flying season is of limited duration. It was exceedingly unfortunate that a severe gale of wind occurred at the height of the flying season in 1897 , which distributed these moths for a distance of 10 or 12 miles to the north and northeast. This gale, according to the data kindly furnished by Mr. J. Warren Smith, of Boston, began in the early part of the night of July 12, the wind blowing steadily from the south with a velocity of from 13 to 16 miles an hour. After midnight it increased in velocity to 20 miles an hour at $2 \mathrm{a} . \mathrm{m}$. (July 13); 25 miles an hour at 8 a. m.; 28 to 30 miles an hour at noon; 35 miles at 5 p. m., and reached 
the maximum velocity of 40 miles an hour late in the afternoon. By midnight the gale had decreased to 14 miles an hour, but increased again rapidly, reaching a velocity of 20 miles an hour at 2 a. m., July 14, and 45 miles an hour at $8.40 \mathrm{a}$. m., then decreased to 30 miles at noon, and 20 miles at $6 \mathrm{p} . \mathrm{m}$. The direction of the wind varied from south to southwest, distributing the moths toward the north and northeast. Since the moths fly ouly by night, the day movement of the wind is unimportant, but it is evident that during the nights of the 12th and 13th, the wind was effective in distributing the pest. Notwithstanding this extensive distribution to the north and northeast, but few moths have been found this year to the east, south, or west of the old colonies.

Although no extensive and critical search has as yet been made to learn the exact and entire distribution of the brown-tail moth in Massachusetts, it is known to occur to a greater or less extent in the following eities and towns: Arlington, Belmont, Boston, Burlington, Cambridge, Everett, Malden, Medford, Melrose, Revere, Saugus, Somerville, Stoneham, Winchester, and Woburn. It is probable, from the very nature of the case, that it already has even a wider distribution than the above would seem to indicate.

\section{LIFE HISTORY.}

The moths are on the wing about the middle of July and each female lays from 200 to $300 \mathrm{eggs}$ in an oblong cluster on the under side of a leaf near the tip of a branch, covering them with a dense mass of brown hair from the tip of the abdomen. These eggs hatch early in August, and the young caterpillars feed only upon the epidermis of the leaves, causing them to turn as brown as though they had been burned; and, as the leaves of these trees were devoured in the spring by the preceding generation, the trees may be practically defoliated twice in a season. The caterpillars also attack the fruit of the apple and pear. While still young they begin to make a regular dwelling in which they hibernate during the winter. This habitation is constructed at the ends of the twigs, and is made by drawing together a few leaves, lining them with silk and surrounding them with a mass of silken threads. These tents are so firmly fastened to the twigs that they can rarely be removed without using considerable force.

The young caterpillars retire into these tents late in September and hibernate during the winter, emerging again about the middle of $\mathbf{A}_{\text {pril. }}$ They then feed upon the buds and later upon the leaves, devouring their entire substance except the midrib, and in leaves having strong. ribs, like those of the maple, all the larger ribs are left untouched. When the caterpillars are numerous, they devour not only the buds, leaves, and blossoms, but even the green fruit.

When the eaterpillars are done feeding, which occurs from the first to the middle of June, they transform to pupe among the leaves, spin- 
ning an open cocoon of coarse silk. In about a month the moths emerge, and after mating, lay their eggs.

\section{RELATIVE PROPOR'IION OF THE SEXES.}

My assistant, Mr. Kirkland, from whose observations I have taken the more important facts in this paper. collected a large number of the pupe in 1897, and the moths emerged as follows:

\begin{tabular}{|c|c|c|c|c|c|}
\hline Date. & Males. & Females. & Date. & Males. & Females. \\
\hline 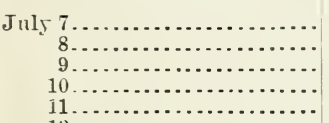 & $\begin{array}{r}5 \\
12 \\
41 \\
153 \\
32\end{array}$ & $\begin{array}{r}2 \\
8 \\
38 \\
135 \\
46\end{array}$ & 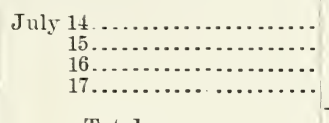 & $\begin{array}{r}21 \\
9 \\
0 \\
1\end{array}$ & $\begin{array}{r}53 \\
12 \\
0 \\
3\end{array}$ \\
\hline 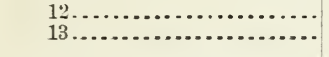 & $\begin{array}{l}64 \\
61\end{array}$ & $\begin{array}{r}54 \\
100\end{array}$ & Total.............. & 399 & 451 \\
\hline
\end{tabular}

IRRITATION CAUSED BY THE HAIRS.

While in the larval and pupal stages these insects are the source of a great deal of annoyance from the intense irritation which is caused by their hairs when they come in contact with the skin of a person, especially when one is perspiring. Many persons in the infested region suffered so severely as to require the aid of a physician. Some of the gipsy-moth employ'es were so badly affected in the work of destroying the caterpillars the present season that the chemist employed on the work, Mr. F. J. Snith, was directed to investigate the matter, to ascertain what was the real cause of the irritation, and to discover, if possible, an antidote. These investigations are not yet completed, but so far as alı eady carried seem to disprove the idea at first entertained that it was caused by formic acid; nor can anything be extracted, as Mr. Smith informs me, that will irritate the skin.

Mr. Smith made extracts from molted caterpillar skins with water, alcolıol, ether, chloroform, and petroleum ether, a list of solvents that he thinks would dissolve anything in the nature of organic acids or alkaloids if they were present. In the water extract the water becomes slightly colored, but does not become charged with any nettling matter. The alcoholic extract remores a great many spines, which may be seen floating on the surface of the liquid. Ether gives an extract a little more pronounced than chloroform, both removing the spines in large numbers. If the unfiltered extract be rubbed on the skin it produces the nettling sensation, while the filtered extract does not. From these experiments Mr. Smith is inclined to think that the irritation caused by the spines is mechanical and not due to chemical substances. Further investigations, however, may lead to different conclusions.

The nettling of the skin may be caused by contact with the caterpillars, both old and young, or the cocoons, but in the latter case contact is not necessary, as the hairs from the cocoons are blown about by the 
wind. An English journal mentions the fact that travelers are often affected when the wind blows strongly from infested hedges along the side of the road.

FOOD PLANTS IN AMERICA.

The brown-tail moth does not appear to have so wide a range of food plants as the gipsy moth, yet the number is so large and the value of many of them so great that this insect must be classed among the serious pests.

It has already been found feeding on the following species:

Basswood, Tilia americana.

Geranium, Geranium sanguineum.

Grape, Titis cordifolia.

Virginia creeper, Ampelopsis quinquefolia.

Sugar maple, Acer saccharinum.

White maple, Acer dasycarpum.

Sycamore maple, Acer pseudo-platanus.

Red clover, Trifolium pratense.

Wistaria, Wistaria conse fuana.

Plum, Prunus domestica.

Cherry, Prunus arium.

Wild black cherry, Prunus serotina.

Peach, Prunus vulgaris.

Spirea, Spiraa thunbergii.

Raspberry, Rubus strigosus.

Blackluerry, Rubus villosus.

Strawberry, Fragaria virginiana.

Rose, liosa nitida.
Crab apple, Pyrus coronaria.

\section{Pyrus pinnatifida}

Pear, Pyrus communis.

Apple, Pyrus malus.

Quince, Cydonia vulgaris.

Japan quince, Cydonia japonica.

Currant, Ribes rubrum.

Gooseberry, Ribes grossnlaria.

Weigela, Teigela rosea.

Burdock, Arctinm lappa.

White ash, Fraxinus americana.

Plantain, Plantago major.

Swamp dock, Rumex verticillatus.

Curled dock, Rumex crispus.

Rhubarb, Rheum rhaponticnm.

American elm, Ulmus americana.

Black walnut, .Juglans nigra.

Weeping willow, Salix babylonica.

The majority of the plants in the above list were attacked by the caterpillars when migrating from defoliated pear orchards. Pear seems to be the favorite food plant of this insect in the infested region, but the winter webs have been found on pear, apple, quince, plum, cherry, peach, oak, maple, elm, rose, and grape.

\section{PARASITES.}

Three parasites have been bred from the pupe of the brown-tail moth in this country: Phcogenes hebe Cr.; Diglochis omnivora Walk.; Euphorocera claripennis Macq.

A large number of unnamed dipterous parasites and multitudes of Diglochis have been bred from the pupe the present year. The work of Diglochis is worthy of special commendation.

\section{PREDACEOUS ANIMALS.}

Podisus serieventris Uhl. has been found destroying the caterpillars. The Baltimore oriole, black-billed cuckoo, crow-blackbird, and English sparrow have also been observed feeding on these insects. Mr. Kirkland wrote me as follows: "Whatever may be the sins of the English sparrows, we must give them credit for destroying large numbers of 
brown-tail moths. Not only do these birds eat the moths themselves, but they also feed them to their young. I saw the sparrows repeatedly hunting along fences and carrying off the resting moths to their nests in July of the present year. At Somerville last year it was no uncommon sight to see flocks of twenty or more sparrows collecting the moths from a picket fence."

Bats feed continuously on the flying moths at night. Their work is noiseless, but can be followed by watching the falling wings. Bats were seen feeding on the moths around an electric light in Malden on the night of July 1t, 1898, and on the following morning 200 wings of the brown-tail moth were counted on the ground beneath that lamp.

Toads must also be reckoned in the list of the enemies of this insect. They devour the caterpillars during the early summer and the imagos later in the season.

Electric are lights destroy large numbers of these moths, chiefly males, however. Under an are light in Somerville on the night of July 16, 1897, at 3 a. m., 236 males and 71 females were counted. Under a second are light 29 males and 11 females. Under a third light, 7 males and 4 females, and under a fourth were counted 3 males and $t$ females. Are lights also attract hundreds of moths, mostly females, that alight upon the poles and houses in the vicinity, where they remain till the next day, when they fall an easy prey to the English sparrows.

\section{EXPERIMENTS WITH INSECTICIDES.}

In the early part of this season, as no provision had then been made for work against the brown-tail moth, though the bill which has since become a law was before the legislature, it was decided to perform a few experiments upon this insect with some of the more common insecticides. For this purpose a number of badly infested pear trees from 10 to 15 feet high, and containing from six to ten undisturbed winter webs, were selected in the southern part of Malden and sprayed May 19, 1898. The caterpillars were at that time in the second and third molts.

The first tree was sprayed with arsenate of lead, 1 pound to 150 gallous of water. In two days no results were apparent. In three days the stripping of the trees had ceased. In four days 50 per cent of the caterpillars were dead. In seven days 90 per cent were dead, and in thirteen days all were dead. The second tree was sprayed with 2 pounds of arsenate of lead in 150 gallons of water, and the results were very similar to those on the first tree. The third tree was sprayed with arsenate of lead, 5 pounds to 150 gallons of water. In four days 80 per cent were dead, and in nine days all were dead. The fourth tree was sprayed with arsenate of lead, 10 pounds to 150 gallons of water. A few were dead in two days, 50 per cent in three days, 80 per cent in four days, and all were dead in six days.

The fifth tree was sprayed with Paris green, 1 pound to 150 gallons of water. In three days 10 per cent were dead, 50 per cent in four days, 
70 per cent in six days, 90 per cent in nine days, and all were dead in twelve days.

The sixth tree was sprayed with Sheele's green, 1 pound to 150 gallons of water. No results were visible in two days, but 5 per cent were dead in three days, 25 per cent in four days, 50 per cent in six days, 75 per cent in nine days, 95 per cent in twelve days, and all were dead in fifteen days. This insecticide burned the foliage quite badly, while neither of the others caused any injury whatever.

There was a great deal of rainy weather at the time of these experiments, and no glucose was used in any of them. We must conclude from the results obtained that the brown-tail moth succumbs to arsenical poisons as readily as our common native insects, and does not possess the power of eliminating poison to any such extent as the gipsy moth.

\section{REMEDIES.}

The remedies generally adopted for the brown-tail moth are to cut off and burn the webs during the winter while the young caterpillars are still within them. Mr. C. W. Minott, one of the superintendents of the gipsy-moth work, called my attention to the fact that some of the webs fall off and the caterpillars pass the winter in them on the ground. In this case they may ascend and attack trees in the spring that were supposed to have been entirely cleared.

\section{LAWS IN MASSACHUSETTS RELATING TO THE BROWN-TAIL MOTH.}

Inmediately following the discovery that the brown-tail moth had made its appearance in this Commonwealth, the attention of the governor was called to the danger that threatened because of this pest, and his excellency sent a message to the legislature concerning the matter. A bill was then introduced authorizing and directing the board of agriculture to undertake the work of exterminating this insect, with an appropriation of $\$ 6,000$. Upon this failing to pass the legislature, another bill was immediately introduced, which became a law June 11, 1897. This law made it the duty of the city or town government within whose precincts the pest was discovered, to take immediate steps for its extinction and to prevent its spread. It was also made the duty of the board of agriculture to cause inspectious to be made, upon receipt of notice from local authorities, or whenever they had reason to suspect the presence of the insect in any city or town, and to furnish the local authorities with printed information concerning methods of dealing with the pest. Severe penalties were imposed by this law in case of neglect or refusal to comply with the requirements of the statute. This law was only partially operative, and, like similar laws in Europe, did not prove entirely successful. During the winter of 1897-98, however, as soon as inspection was made and notice of infested 
estates sent to the local anthorities, an attempt was made to enforce the law. In Somerville, Cambridge, and Medford the trees along the streets were cleared by the city authorities, and the owners of the infested estates were required to clear the webs from their trees. In other cities and towns but little was done, the people having experienced no inconvenience from this insect, allowed the work to go by default. In Somerville, where the pest stripped the trees over large areas, and the caterpillars migrated from one orchard to another in great swarms, and also where many people suffered severely from the irritating effects of these caterpillars, the authorities and citizens carried on a somewhat systematic campaign against this insect in the winter of 1897-98. As a result, there were practically no brown-tail moths last spring in all those places that were successfully worked over.

Local work as carried on last winter was uneven. Where a vigorous effort was made to carry out the law good results followed; but where half measures were adopted the results were unsatisfactory. Somerville and Medford tried to exterminate the moth, but Malden, adjacent to these two eities, made no effort. This year the southern part of Malden has raised a sufficient number of brown-tail moths to restock the greater part of Medford and Somerville.

From the experience of the past year it seems very doubtful whether it would be possible to exterminate this insect from so large an extent of territory as it now occupies in this country if the enforcement of the law be left to the town or city authorities, but it may be possible to keep it more or less under subjection, as is done in Europe, and as was done in some of the above-named cities the past year.

During the last session of the legislature the following law was enacted putting the work of exterminating the brown-tail moth into the hands of the board of agriculture, and revoking the previous law relating to this insect:

Whenever the pest known as the brown-tail moth is discovered in any city or town of this Commonwealth, it shall be the duty of the State board of agriculture to take immediate steps to prevent its spread; and, in the discharge of the duty imposed upon said board by this act, said board is hereby rested with all the powers now conferred upon it by law in exterminating the gipsy moth, and may expend of the money heretofore appropriated for the extermination of the gipsy moth a sum not exceeding ten thousand dollars.

Any person who shall purposely resist or obstruct said State board of agriculture or any person or persons under their employ, while engaged in the execution of the purposes of this act, shall be punished by a fine not exceeding twenty-five dollars for each offense.

It shall be unlawful for any person knowingly to bring the insect known as the brown-tail moth, or its nests or eggs, within this Commonwealth, or for any person knowingly to transport said insect or its nests or eggs from any town or eity to another town or city within this Commonwealth except while engaged in and for the purposes of destroying them. Any person who shall violate the provisions of this section shall be punished by a fine not exceeding two hundred dollars, or by imprisonment in the house of correction not exceeding sixty days, or by both said fine and imprisonment. 
The distribution of this moth about Boston was discussed by Mr. Kirkland.

Before the session adjourned, on motion of Mr. Howard, a nominating committee was appointed by the president, consisting of Messrs. Howard, Weed. and Fernald.

\section{AFTERNOON SESSION, FRIDAY, AUGUST 19, 1898.}

The programme committee had associated for the afternoon a series of papers relating more particularly to scale insects. The first was presented by Mr. Smith, as follows:

\section{THE DISTRIBUTION OF THE SAN JOSE OR PERNICIOUS SCALE IN NEW JERSEY.}

By John B. Sмıтн, New Brunswick, N.J.

We have more, and at the same time less, San Jose or pernicious scale than ever before in our State: New Jersey is credited with having distributed this species throughout the Eastern United States, and to a large extent this is probably so. Yet, on the other hand, New Jersey has received from other States a considerable amount of infested stock, which it has been very difficult to locate, so that honors are tolerably even.

When I say that we have less scale than ever before, it means that in districts where the scale has been known to exist in years past ener. getic efforts have been made to stamp it out, in most cases with good success, and there is not now one badly infested orchard or one that has been badly infested which is not in much better condition than at any time since the infestation was discovered.

When I say that we have more than ever before, it means that a num. ber of new scaly orchards have been discovered, or new localities into which the scale was introduced from points other than our own nurseries.

I wish here to claim for at least one of the New Jersey nurseries that unintentionally distributed the scale the credit of doing all in its power to enable infested points to be discovered; for the Parry Brothers have always furnished, on request, complete lists of all their customers in the States from which the requests came; and lately the Lovett Nursery has found that this was the best policy for them as well. I can not say that my requests to nurseries in other States who have sent scale into New Jersey have been equally well treated.

I have in the past called attention to the fact that the line formed by the red shale in New Jersey was in a way a boundary which limited the distribution of the scale, and have also detailed experiments which seem to indicate that the shale itself had little or nothing to do with their development-that is, it was not the character of the soil which 
prevented the multiplication of the scale. This year my division of the State has been broken into, not badly by any manner of means, but sufficient to demonstrate that it was not the shale, but some other factor which limited the spread of the insect and resulted in keeping the northern half almost free.

Here the introduction of the scale from other States has assumed considerable importance. Throughout the southern half of the State, using that term very roughly to indicate everything below Middlesex and Monmouth counties, the orchardists have beeu chiefly supplied by the Parrys and the Lovett Nursery; bat some also by a small nursery near Mount Holly, which has no foreig" trade and need not be specified therefore for the protection of out of-State orchardists. This little nursery has, in a way, done more harm than either of the larger ones, because its very insignificance enabled it to escape detection at the beginning. While, on the other hand, the energy of its proprietor has made it an important factor, because he did much personal canvassing and secured many orders which were difficult to trace up later on.

North of the counties above mentioned almost all the stock found infested has come from other States. This again has been in some respects fortunate, because in no case has the infestation extended beyond the orchard in which it was originally received, and curionsly enough the insect has been unusually fatal on the infested trees and shrubs. Fifty thousand currant bushes were received by one dealer from northern New York, a region where the scale is not officially known to exist. The nursery had a certificate, and the stock escaped inspection in New Jersey for that reason. It was discovered within a year after it nad been set out, and what was left has been since destroyed. So far as I have been able to learn there has been no spread from this point of infestation into the immediate vicinity, but some of the stock had been sold into other States before the trouble was discovered. The nurseryman immediately notified all his customers for this stock and offered to replace it if that previously sent was destroyed. In almost every case he was invited to duplicate his order, but there is no proof that the stock previously sent had been really taken out.

It was with some surprise that I received a few badly infested specimens from Somerset County, N. J., in June, and on investigation found a small peach orchard which had been almost utterly killed out by the scale. It is one of those unfortunate cases where the owner of the iarm lives in another State and gets a new tenant almost every year, so that it is practically nobody's business to look after the condition of the place. We are on the red shale here sure enough, and there can be no question now that the character of the soil, or rather the presence of red shale, does not serve to check the insect; but fortunately here also the scale seems not to have spread from the original point of infestation. An appeal to reason and a slight indication that the powers of the law would be invoked, if reason was not successtul, was 7184-No. $17-3$ 
sufficient to induce the owner to order out the infested orchard. A large proportion of the trees came from Dansville, N. Y., and were peach trees probably not grown by the nurseryman who sold them. This gentleman held a certificate, and on being notified of the condition of affairs has evinced a considerable amount of fear lest his name should be mentioned in this connection. A number of apple and pear trees on the same farm also proved to be scaly, and these came from Long Island, from a nursery known to be infested by the insect.

In Warren County, N. J., I have found three points in which the scale is, or rather was present, and most of the stock there came from Alabama. The nursery from which this stock was sent out also has a certificate, and I presume the stock that is sent out at the present time is at least as good as that received by us in New Jersey.

I have found several other cases in other localities where the scale is traceable, without any doubt, to other than New Jersey nurseries, and two of these cases are among the worst we have. Here the infestation came on Duchess pears from Geneva and Rochester.

I do not have to tell most of the members of this association one of the secrets of the nursery business, for those certainly, who have had to do with inspecting nurseries, know about it tolerably well. You know that almost every nurseryman has a specialty which he has learned to grow to the best advantage or for which his land is peculiarly adapted, and that he buys almost everything else; he may have 200 or 300 acres in nursery stock, and it may be chiefly one particular kind of fruit, though in his catalogue hundreds of varieties are listed. In New Jersey we grow peaches-I was going to say for the world, but certainly for a large part of the United States. Our annual crop of these nursery trees runs far above the million, and many of them are sold as home-grown stock by dealers in other States. I have reason to believe that some of the trees that went out of the State with my certificate came back into it with one bearing quite another name. One nursery alone in Mercer County had one and one-half millions of trees in 1897, of which either one-half or three-fourths of a million became available that season, the number each year depending somewhat upon the fluctuations of trade. We raise, of course, in our State a large number of other fruit trees, but in a general way it may be said that most of our apple and pear trees (Kieffers excepted) come from the North. Most of our Kieffers come from the South and nearly all our plums come from that region. Almost all the plum trees of recent setting that have been found to be infested in New Jersey have been grown in Southern States, though they may have been sold by New Jersey nurserymen.

During the past year there have been received in New Jersey under certificate scaly trees from Florida, Alabama, Maryland, New York, and Pennsylvania.

It is not intended to make it a reproach to the gentleman who signed these certificates that this was the case, for I am perfectly well aware 
that some scaly trees have gone out from New Jersey with my certificate attached. I do not believe that I saw all these trees; in fact, I know that some were bought by the nurscryman who sent them out. But, on the other hand, I would not feel particularly guilty if it were proved that I had really been in some of the blocks from which the scaly trees were taken. I have no objection to admitting to an assemblage of this kind my belief that in a lot of 250,000 peach trees in full foliage a few may escape my observation, even if they are scaly.

When we come to the point where the nurseryman puts his certificate on all the stock that he sends out irrespective of where it is grown, of course the danger of scaly stock getting out under certificate becomes the greater. One New York nurscryman sent his tags with printed certificate to his correspondent in Pennsylvania, and this correspondent filled directly all orders for the particular stock grown by him. All parcels were tagged from the supply furnished and all bore printed certificates, though the only stock actually examined was growing in Wayne County, N. Y.

This is perhaps wandering a littlo from my subject, but it is in some measure necessary, because it is important to indicate the fact that limiting the scale distribution, even in a State where it is known to exist, is by no means an easy task, because the sources of infestation are so numerous and may be in localities of which no suspicion has been entertained. It may also serve as a hint to some of my good friends who have said uncomplimentary things of New Jersey that their work of locating the scale is not all done when all who have been supplied from that State have been visited.

Almost all, if not all, the nurserymen in what may be termed the nursery district of central and northern New York have certificates, yet there is no doubt that thousands of scaly trees have been sent out by them and not a few into New Jersey, else I could not speak of the matter so positively. These trees will not, as a rule, be particularly examined when the question of the presence of scale arises, because the locality is not under suspicion, and only when it becomes so bad that the condition of the trees arrests the attention of the grower will they be brought to the attention of the entomologist. It goes without saying that in a region of small farms, where almost every one contains some fruit trees, personal inspection of all of them is hardly feasible.

It is therefore impossible for me to say with certainty that I know all the infested points in our State, but I think that I know sufficient to speak of the general distribution. In no State has so much literature relating to the scale been so generally distributed; in no State do farmers' institutes reach so large a proportion of farmers; in no State is it easier to reach every locality by rail within a few hours, and in no State has there been a more systematic effort to learn, by correspond. ence and personal visits, the exact location of infested orchards. There have been published in the past maps showing the general distribution of the scale in the United States, and these' give, quite unintentionally, 
no doubt, yet very effectually, an erroneous idea of the condition of affairs with us. Compared with the rest of the United States, New Jersey shows only as a very little odd corner. Usually a rather prominent, easily seen black spot or blotch is used to represent a scale location, half a dozen of which will go very comfortably into Ohio or Illinois; but when you come to put ten or a dozen of them into New Jersey there is nothing left of the State. This gives us a very ugly showing, yet when the infestation is actually marked in some proportion to the size of our State the situation is not quite so bad.

It is for this reason that I call your attention to the accompanying map. ${ }^{1}$ You will see that in a general way there are two, possibly three, scale districts. One of them, and much the larger, extends along the Delaware from a little south of Kinkora almost to Camden. The stretch is perhaps 25 miles, and every township in this stretch may be said to be scaly. The points from which this region became infested are Parry and Mount Holly, and therefore there is a greater circle around both of those places than there is in any other direction. This stretch is the most dangerous, because of the number of villages with gardens which it contains, and the consequent number of persons to be dealt with.

The second district is along the Monmouth shore, and has for its center of distribution Little Silver. Nearly all the growers in that district purchased their trees from the Lovett Company, which was the largest nursery in that vicinity, and therefore we have here another pretty generally infested territory. I have marked the points actually known here, but there are probably more in the same general locality. There is, however, more clear than infested fruit land in each case. It is in the Delaware River territory that the scale has escaped into woodland.

These are the only real centers that exist in New Jersey. In most of the other points only one or two isolated orchards are known to exist, and in some cases less than half a dozen trees. The possible third district is in Atlantic County, where from Egg Harbor City to Pomona there are more infested orchards than at any one other point, save the two previously limited. You will see that there is a point in Cumberland County, at Vineland, and another at Bridgeton; but so far as I am aware there is no extension from the original point of infestation in either case. In Vineland the infested trees were in a city garden, and I believe that they have been taken out. Near Salem, in Salem County, there is an orchard of about 150 small trees infested; at Shiloh three infested trees were taken out and destroyed; at Tuckahoe a few southern plums were killed, and at Glassboro a lot of New York Duchess trees are infested. Aside from that, the entire soutliern region in New Jersey bordering on Delaware River and Bay is uninfested. I found some scaly trees at Hammonton, and on the faith of a report have marked

${ }^{\prime}$ Large map of New Jersey, showing scale-infesterl districts, exhibited in connection with paper. 
Winslow as scaly, though I have not received actual specimens. Possibly there may be more infested trees than I know in Hammonton gardens, but I am sure the orchards are not infested to any extent, because they are usually so well kept that the insect would have reached me ere this were it present. There is said to be some infestation in the vicinity of Trenton; but I have never been able to find it, and the report rests on rumor more than on positive evidence. In Middlesex County there are two badly infested orchards near Prospect Plains, but they are somewhat isolated, and I do not believe that there has been any spread from them. A careful canvass of the territory between Hightstown and Jamesburg failed to show any other points save one, where three scaly Alabama plum trees were ordered and taken ont. There is also a point of infestation in New Brunswick; but this is in my own garden and intentionally established, and therefore I do not feel that there is any very great danger from that point. In fact, the beasts are so nearly exterminated now that I am afraid to make more experiments for the present lest the stock be completely exhausted. Near Elizabeth, in Union County, a lot of 50,000 scaly currants were introduced from New York State; but I believe that this has been entirely rooted out, though I have left the blue mark present. In the back gardens of Jersey City Heights and extending northward for some little distance the scale is distributed, and this infestation appears again at Hackensack, where there is one point, and at Paterson, where there is another. At Montclair some of the gardens have scaly trees which are dying or being taken out. I have received samples of scale from the vicinity of Morristown, in Morris County; but am informed that the insects died out without any effort on the part of the owners of the trees. Near Bedminster, Somerset County, there is one infested orchard which has been already referred to, where all the trees came from New York State. This orchard has been taken out, but the region, of course, is under suspicion at the present time, and I am trying. to locate other trees sold by the same agent. Finally, there are three points in Warren County where each infestation is confined to a very small district, and in two cases this came from a lot of plum trees that was received from one of the Southern States. The trees were sold by a local nurseryman, and most of them died the spring after they were set out. A few of them are yet living in one orchard near Washington, where several are infested by the scale. At both the other points the infested trees were so few in number that the owner had no hesitation in digging them out. The complete destruction of the infestation at Delaware $I$ verified myself only a few days ago.

Now, if you will compare the scaly district as it actually exists with the actual size of the State you will see that it is rather unfair to charge against us such a general infestation as should act as a deterrent to all purchasers of fruit trees. A number of our tree growers have suffered severely from the loose charges made against our State, 
and on the other hand the desire to save a few pennies has induced men from the very State where warnings against New Jersey were most urgent to buy largely of the most discredited of all our dealers.

I can speak of the effect of the scale only as I have seen it in New Jersey. We have had it with us as long as it has been anywhere in the East, perhaps longer, if we have distributed it so generally as it is charged. It is certain that some of the orchards now infested have been scaly for nearly ten years. I speak for New Jersey only; but, except in the case of young plum and pear and peach trees generally, many of these are very little the worse for their infestation. Some hedges of Japanese quince at Moorestown are simply swarming with the insects, yet they were up to this spring, when I last saw them, quite as flourishing as those that are free; and a number of other plants show little or no ill effects.

It seems also to be almost probable that the scale is to some extent losing vitality with us. It is not nearly so bad on some old infested trees that have never been treated as it was three years ago. Whether this is due to the fact that the trees themselves are developing a resisting power, or that the climate is taking hold of the insects, it is certain that a smaller proportion of them survive, and also that the broods are decreasing in number. This was marked to some extent last year, and it is still more marked during the present season.

Heretofore the second brood was found hatching in great abundance before the middle of July. This year it was rare to find a full-grown scale of the first brood ready to reproduce before the 20th. In fact, a careful examination made of a badly.infested orchard on August 5 showed that there was not, even then, any general hatching that would cover a tree with a mass of the second brood of young. There was quite a number of larvæ and there were a few recently set seales, but there was none of that general hatching that was noticeable in previous seasons. In fact the August 5 status in 1898, with much more favorable weather, was behind that of July 15, 1897. Another feature that deserves some attention in this connection is that where an orchard is treated at all it seems to check development as well as to kill a very large percentage of the larvæ that set on a treated tree. This is particularly true where kerosene has been used, for here the majority that survive the treatment never get beyond the white stage.

The subject of remedies is not a part of my present essay. The subject of distribution carries with it the question of increase or decrease, and I am happy to be able to say positively that there is a very general decrease in the amount of scale in New Jersey as compared with the two years last passed. I do not mean to say that at any one point where many large trees were badly infested the scale has become entirely exterminated. I do mean to say that a number of heretofore badly infested orchards have been so far cleared that the scale does no mischief, and that their owners understand the subject sufficiently well 
to prevent the insect from ever causing them any additional injury. The two nurseries that originally distributed the scales are practically clean, and their arrangements for growing stock at the present time are such that I believe that material received from them is about as safe as that received from any district where scale has ever been known to exist. There is no doubt that in the Delaware Valley region the scale has run away. I have every reason to believe, however, that where it has run into wild land it is meeting sufficient natural checks to prevent its doing any particular harm to the vegetation that it infests. I am not sure that this escape will not prove to be a benefit for the reason that natural enemies can breed here undisturbed, and if there is such a thing as mastering it these enemies will in due time find their way into our infested orchards. I do not believe it possible to say definitely that any district in which a scaly tree has once stood for an entire season is completely free from the scale. It is known to all who have had any practical experience that it is just as easy for a bird to carry larva a mile as it is to carry it from one tree to another. Probably most of you have also had the experience of finding isolater or even half a dozen scales on several adjacent trees from which no young had ever hatched. This was due, of course, to the fact that only one sex had been transferred or that the two sexes were so widely separated on the tree that the male could not find the female.

I have been carrying on an elaborate series of experiments during the present summer in the direction of controlling or destroying the scales, and these are resulting very satisfactorily. The season, however, ss not sufficiently far advanced to give results that may be considered in any way final.

Mr. Johnson followed with a paper entitled:

\section{HYDROCYANIC ACIDGAS AS A REMEDY FOR THE SAN JOSE SCALE AND OTHER INSECTS.}

By Willis G. Johrsox, College Park, Ma.

After a preliminary inspection of the orchards and nurseries upon my arrival in Maryland, I found such an alarming condition of affairs that I deemed it advisable to begin my experimental operations with hydrocyanic acid gas without delay, as I had plenty of material upon which to work. Accoriingly, in November, 1896, after constructing a fumigatorium, I began my experiments upon badly infested peach, plum, pear, apple, and nectarine stock direct from the nursery, and one-year old pear, plum, and apple trees from the orchard. Many preliminary tests were necessary, using the potassium cyanide from 0.12 to 0.25 grams per cubic foot of air space inclosed. The time of exposure was also varied from fifteen to sixty minutes. 
By these tests we concluded (1) that nursery stock and young trees of one and two years old to be replanted should be exposed to the gas for thirty minutes or longer and (2) that from 0.18 to 0.25 grams of potassium cyanide should be used for every cubic foot of air space inclosed. On large bearing trees 0.20 grams of cyanide gave us the best results.

At first the amount of acid we used was the same as the cyanide, while the water was three times that quantity. We followed this formula, as it had been generally used and recommended in California and by the United States Department of Agriculture at Washington. Our results however were not satisfactory. The cyanide in all cases did not act as it should, and the residue was at times blackish instead of being bluish or milky. We then began a series of experiments to determine the relative amounts of acid and water to use with a given amount of cyanide in order to get the best possible results. At last we observed that our results were satisfactory where we used a half more acid than cyanide and a half more water than acid. In other words, if I used 2 ounces of cyanide I would require 3 ounces of acid and $4 \frac{1}{2}$ ounces of water.

Having concluded these tests, I again began my work upon young trees in March, 1897, and continued it until April 15 of that year. All the trees used for these experiments were badly infested, and after fumigation were set out in an isolated field and watched carefully throughout the spring, summer, and fall of 1897 and spring of 1898 . Up to the present time I am happy to report not a living scale has been detected upon any trees except those used for checks, all of which were destroyed June 7, 1897, at which time the first young appeared.

So conclusive and satisfactory were these results, I was prompted to begin an extensive experiment in a nine-year-old pear orchard the fall of 1897. My equipment, perhaps the most extensive of the kind ever gotten together in the East, consisted of twelve tents Two of these were kindly loaned by Dr. L. O. Howard, United States Entomologist, two more were bought by the Maryland Experiment Station, and eight were secured through the generosity of Capt. Robert S. Emory, one of Maryland's most successful and enterprising fruit growers. With this equipment of tents, 150 pounds of cyanide, and 3 carboys of sulphuric acid I began an experiment full of almost insurmountable difficulties. Although successful upon citus trees in California, it was an open question whether the gas method could be used economically and to advantage in deciduous orchards in the East and South, where climatic and local conditions are very different. Anxious to settle this question beyond all doubt, I set out to determine the following points:

(1) The physiological effect of the gas upon the tree.

(2) The effect of the gas upon the San Jose scale.

(3) The practical utility of this method in large growing orchards in the East and South during all kinds of weather conditions.

To determine the first two points many preliminary experiments were 
necessary, and when these were finished the third point was taken up and continued from October 16 to November 27, 1897.

The orchard chosen for these operations belongs to Mr. Emory, and contains about 2,500 nine-year old dwarf Bartlett pear trees, which had become infested with the scale from an adjoining young Lawson pear orchard. All the trees were full of foliage. The scales were breeding and active, and, taking it all in all, the conditions could not have been more favorable for my experiments. The preliminary tests were begun September 27,1897, and continued at all hours of the day and at night, and were finished October 1.

\section{These tests show conclusively-}

(1) That the gas is not injurious to foliage during sunshiny days, late in the fall, between $9 \mathrm{a} . \mathrm{m}$. and $4 \mathrm{p}$. m. In every instance where trees were treated between these hours, the foliage was singed. In several instances it was perfectly brown, looking much like the effects resulting. from a heavy frost. One important point was noted, however, that the leaf petioles were blackened about two-thirds their length, the base being perfectly green, and, therefore, the leaves fell readily a few weeks later. Another point that should be noted in this place, is the fact that the function of the foliage had been performed; consequently, we used the gas much stronger than we would have done at any other season when the trees were in full foliage.

(2) That the dormant leaf and fruit buds on the trees treated with gas sufficieut to turn the leaves brown in the fall are not injured.

(3) 'That leaves which have heen injured by the gas fall readily and do not remain clinging to the tree.

(4) That trees treated in the morning before 9 and in the afternoon after 4 have the foliage very little affected by the gas.

(5) That trees treated at night with very strong doses of gas do not have the foliage, dormant leaf, and fruit buds affected at all, even where double the amount of gas ordinarily used is generated.

(6) That the San Jose scale is entirely destroyed by the gas when applied during a calm, sunny, or cloudy day.

(7) That the cost of treatment, aside from the equipment, is less than for whale-oil soap.

(8) That the gas can not be used when the foliage is wet with dew, fog, or immediately after a rain.

(9) That the gas can not be used with tents upon trees under 5 feet in height with satisfactory results.

In order that I might report the definite and final results of these experiments, I made a careful examination of every tree in the orchard on Tuesday and Wednesday of this week. Where there were hundreds and thousands of scales breeding on the trees at this time last year not one cau be found now, except upon trees under 5 feet in height and those fumigated when the foliage was wet with dew or fog, or immediately after a rain, and even on these trees the young larvæ are very 
few as compared with their numbers at this time last year. Where the fruit was much pitted and scarred by the scale last year not one has been seen upon a pear thus far this season.

In all, the experiment is thoroughly satisfactory, in that it demonstrates by actual trial that this method can be used in our largest bearing orchards, even under the most adverse conditions, with excellent results.

I do not recommend the adoption of this method to the average fruit grower; it must be in the hands of an expert, thoroughly familiar with the process in every detail and the conditions which insure success. Where the scale is confined to a few trees under 15 feet in height it is the most effective remedy for its suppression.

The gas can also be used in the spring in peach, plum, and apple orchards, after the buds have begun to unfold. A block of one hundred six-year old plum trees at Annapolis Junction was fumigated March 17 and 18, 1898, and up to the present time not a living scale has been found upon any trees, except those sprayed with 50 and 100 per cent gasolene. The trees in this orchard were very badly infested, the most of them being so literally covered it was impossible to see the bark at any point on the trunk and larger branches.

Other experiments were conducted in scale infested bearing orchards in May, June, and July, the results of which can not be finally reported at this time, except that no living scales have been found upon any of the fumigated trees.

Much encouraged by the outcome of these experiments, I have applied this method to other insects. Experiments were conducted upon the Euonymus seale (Chionaspis euonymi) December 16, 1897, with most excellent results. The shrubs were very large, some of them being 10 to 12 feet in height and from 6 to 8 feet in diameter. They were literally covered with the scale, and seven of them had been killed, while seven others were still alive.

The treatment was the same as used in the orchard, and not a living. insect has been detected this season.

The apple-leaf aphis (Aphis mali), being very bad in Maryland in oneyear, two-year, and three-year old orchards this spring, I beg:ın some experiments to see if this method could not be applied for its destruction, as it was practically impossible to reach the insects with any spray on account of the curled and folded leaves. Trees covered with tents in the direct sunshine $\left(95^{\circ} \mathrm{F}\right.$.), and fumigated for five minutes, were not injured in the least, and all the lice were killed.

Two-year peach trees badly infested with the black peach aphis ( $A$. prunicola) were treated and exposed in the same manner with identically the same results.

Three-year and four-year old pear and cherry trees, being defoliated by the slug, were successfully treated; but it required a longer exposure. Ten minutes killed all insects, but the foliage was also injured, and I would not recommend its use. 
Aside from outdoor work, lydrocyanic acid gas has, in my opinion, a great future for the destruction of insects in grain bins and warehouses. It has been suecessfully applied to greenhouses infested with insects, and can be used to good advantage, even in private houses, against household pests. I predict a great future for this substance in entomological science.

An illustrated detailed account of these experiments is published as Bulletin No. 57 of the Maryland Experiment Station.

Mr. Alwood pointed out the impossibility of determining with any great certainty the actual distribution of the San Jose scale. He stated that in Virginia he had found no difficulty in controlling this insect. The work had been undertaken promptly and energetically, all infested stock being uprooted and burned and the rest disinfected by fumigation. He claimed to have been the first to use hydrocyanic acid gas, more particularly for disinfecting nursery stock, in the East, and his results had been entirely satisfactory, following the formula given in the reports of the Division of Entomology of the United States Department of Agriculture. He had employed the gas very extensively and expected to continue its use in the future. In Virginia this scale, he said, was practically removed as a destructive factor in orchards. Many infested orchards had been thoroughly freed from the scale with the application of soap and kerosene, and others by fumigation. For orchards he now uses the pure kerosene almost exclusively, and makes the application at any time, thoroughly atomizing the liquid. Of hundreds of trees treated none had been killed. The application had been made at all seasons, but is preferably made in winter. In the fumigation of nursery stosk he had buildings arranged with double compartments, using the rooms in alternation, as a saving of time. Fumigation is continued forty minutes, at the close of which an upper window and a door are opened. The room is not entered until after the lapse of ten minutes. The apple-root louse, Schizoneura lanigera, which is inuch worse in Virginia than the San Jose scale in amount of damage occasioned, he controls on nursery stock by fumigation in the same manner as the San Jose scale.

Mr. Johnson gave a résumé of the distribution of the San Jose scale in Maryland.

A general discussion followed, participated in by Messrs. Smith, Marlatt, Hopkins, and others, on gas treatment, Mr. Johnson reading a portion of a paper by himself relating to the effect of the gas on trees, concluding with some notes on its effect on man and lower animals, and particularly some experiments with a dog and chickens, all of which illustrated the necessity for the greatest caution to avoid inhaling the gas. 
Mr. Smith commended the course of Mr. Johnson in uot publishing the names of nurserymen who were using their best efforts to exterminate the scale and who were distributing none but sound stock.

Mr. Marlatt pointed out the necessity of knowing the absolute value of the chemicals employed in the case of formulas requiring very definite weights and amounts of the materials. He pointed out the variability in the strength of potassium cyanide, and that the strength of sulphuric acid used is not indicated in the reports of experiments made by Mr. Johuson.

Mr. Hopkins presented the following paper:

\section{SOME NOTES ON OBSERVATIONS IN WEST VIRGINIA.}

By A. D. Hopkiss, Morgantown, $W \cdot T a$.

The SAN Jose Scale (Aspidiotus perniciosus) has attracted more attention in West Virginia during the past two years than any other of our common insect pests. It has been reported from numerous new localities during the past year, many of which I have visited, but only in three places had it multiplied and spread sufficiently to prove destructive. One of these was a large orchard, said to contain 300 trees, near Van Cleresville, in Berkeley County, which was visited in March, in company with Mr. Coquillett, of the Division of Entomology. We found nearly all of the apple trees, the majority of which were ten years old, completely incrusted from the roots to the terminal twigs, and many trees were dead or dying. This orchard was, soon after our visit, thoroughly sprayed with pure kerosene, several barrels having been used, and applied quite liberally. I visited the orchard again on June 29, when, after a thorough examination, only a few living scales were found. These were on a few of the terminal twigs of but one tree. Some of the trees showed no injurious effects of the treatment, while others were quite seriously injured on one side, including the bark on the trunk and branches. Upon inquiry, I learned that, owing to the way the wind was blowing, only one side of the rows of trees could be sprayed during the morning and middle of the day, and that the other side was sprayed later in the evening, and a few of the trees just before a rain. The sides sprayed first were not injured, while all that were sprayed later were, some of them quite seriously.

The other two orchards in which the trees were killed by the scale were found near Seymour, in Lewis County, both five years old from planting. In one of 30 trees only 4 living trees remained, and, in the other, of 75 trees, 9 had died. All the remaining apple and peach trees were literally covered with the scale. On the peach trees nearly all of the scales appeared to be dead, while on some of the apple trees the bark, leaves, and fruit were covered with moving and recently settled young. The kerosene treatment was recommended for these trees, but I have no information as to the result. 
In all of the other orchards in which the scale was found, only a few infested trees occurred, and on some of these most of the scales were dead.

From what I have observed, I am confident that in the few localities in the State in which the climatic and other conditions are favorable for it to multiply rapidly, the pest can be quite easily controlled.

The Forbes scale (Aspidiotus forbesi) appears to be widely distributed over the eastern portion of the State, since I have frequently met with it there on apple and cherry, but only in one apple tree did I find it in sufficient numbers to cause perceptible injury. I found that one of the charactersstic evidences of the presence of this scale is the pitted condition of the infested bark and an absence of a purple condition of the inner bark, beneath the scale.

The aSPARAGUs BeETLE (Crioceris asparagi) was collected near Martinsburg, in Berkeley County, in June of the present year, where I found it quite common in two market gardens, but so far as I learned it had not been recognized by the gardeners as a pest. This is the first record I have of the occurrence of the insect in West Virginia.

The тімотну BILL-BUG (Sphenophorus sculptilis).-This root and stem borer has caused considerable damage in my timothy variety plats during the past three or four years. The larvæ occurred in June to September and the pupæ and adults in August to October. From what I have observed of the work of this species, I am confident that it is one of the prime causes of the early failure of meadows so commonly complained of. It would also appear that the permanent injury caused by this and other enemies of the roots of timothy can be largely prevented by liberal applications of stable manure, tobacco dust, lime, or other suitable fertilizer to the sod immediately after hay harvest.

A TIMO'THY LEAF-MINER also did considerable damage to the growing plant this season. - An adult reared from one of the infested leaves has been kindly determined for me by Mr. Coquillett as Odontocera dorsalis.

THE CLOVER-SEED CHALCIDID (Brucophagus funebris).-Additional evidence obtained from the study of all stages of this insect, together with some observations on its habits, seems to leave no doubt that this interesting little Chalcidid is a destructive enemy of the seed of crimson and common red clover. I also determined that it passes the winter in the seed left in the open field, evidently in the larval stage. The injury to clover seed mentioned by Dr. Lintner in his Eleventh Report, page 152, as that of Grapholitha intersinctana was evidently caused by this Chalcidid, which at the time his report was prepared had not been recognized as a clover-seed pest. The parties sending the damaged seed to him refer to it as being "hulled out like beans eaten by bugs," which is the characteristic appearance of seed from which the insect has emerged. 
A ROSE APHID PARASITE (Ephedrus incompletus) was found to be quite effective in keeping the rose aphids in check in the rose house at the experiment station. I found it on March 19, 1897, and when, according to my request, the ordinary remedies of fumigation and the application of tobacco dust was discontinued, it rapidly multiplied and soon succeeded in keeping the aphids sufficiently reduced to prevent injury to the plant. The aphids infested by the parasites change in color to a deep black, instead of a brown, as is usually the case when infested with parasites. The species was kindly determined for me by Mr. Ashmead.

THE SPRUCE GALL MITE (Chermes abietis) has been observed on cultivated Norway and other spruces at Morgantown, and on the native black spruce, both in the northern and southern sections of the spruce area of the State. In some cases it had apparently caused the death of small trees, and in the northern part of the State, near the Penusylvania line, it was reported as being very common and destructive in the summers of 1890 and 1892.

CERAMBTCID AND BUPRESTID BEETLES, BREEDING IN SEASONED HICKORY.-One of the interesting results obtained from the insectary described in my former paper is that relating to Cerambycid and Buprestid beetles, developing broods three years in succession in one lot of hickory placed in the breeding room in 1896 . The material was from trees cut twice a month and oftener during 1895. In 1896 a large number of beetles and their parasites and predaceous enemies emerged from the wood. In 1897 a larger number of the wood borers and fewer of their enemies appeared, and again this year quite as many beetles emerged as in 1896, but scarcely any parasitic or predaceous enemies appeared. I supposed at first that the late arrivals were simply the result of retarded development of the larvæ, due to the seasoned condition of the wood, but, upon an examination of the material, I found that sections of the wood which were not infested when placed in the house, had yielded quite as many, and in some cases more than those that were. I made still further examination in August, 1898, and found that the wood and bark were infested with young and quite active larvie. The principal species which have emerged during the three years are as follows: Cyllene picta, Xylotrechus colonus, Neoclytus erythrocephalus, and Crysobothris femorata.

LYMEXYLON SERICEUMI.-On June 29, 1897, three females and one male of this rare beetle were cut from a living chestnut tree near my home. I have never collected this insect, except from its galleries in the tree, and there appears to be only a few days in June of each year that they can be had in this manner. This is about the time the first chestuut flowers appear. While I have no additional data to that mentioned in previous papers, I am convinced that the larræ of this species live sereral years before changing to adults. This is evident tiom the fact that when adults are found in the trees, all stages of 
larvæ are also found, from quite small to nearly matured. A long period of development would also account for the rarity of this, one of the most destructive insects of chestnut and red oak timber.

Eupsalis minuta destructive to stave timber.-On July 10, 1897 , I received specimens of wood, from white oak stave bolt, from a cooperage company in St. Louis, Mo., with the statement that the wood was infested with so-called "seed bugs," which was causing serious loss to the stave and cooperage industries. Another larger section of a bolt was received on July 30, in which numerous specimens of very young Brenthid larvæ were found, making microscopic holes entirely through the bolt. Previous observations of the habits of Eupsalis minuta made it plain to me that the larva might be either in the wood of the tree before it was felled, or the eggs deposited after the bolts had been split and piled. Upon further inquiry it was learned that the timber was cut in the winter and spring and left in ricks in the woods until they could be hauled to shipping points during the spring and summer. Thus the ricks of unseasoned wood were naturally both in a position and condition to attract the beetle for oviposition. It was found that the young, almost microscopic larvie, excavated their burrows directly across the grain of the wood in such a manner as to render it worthless for the purpose for which it was intended. The remedy, or rather preventive, recommended was to commence cutting the timber late in the summer and early fall, and endeavor to have the bolts hauled out of the woods before the middle of April, or, if this could not be done, to have the timber split into smaller dimensions and piled so it would be partly dried before the beetles commenced to deposit their eggs in the spring. Keeping the bolts in ponds or streams, or spraying them with strong brine was also recommended, when it was necessary to keep the timber in the woods during the time the beetles were flying.

This insect has since been found in stave timber in West Virginia, and from what $I$ have observed and the information I have obtained, the loss occasioned by this so-called "seed bug" aggregates many thousands of dollars each year in this and other States, which, it is believed, can be largely prevented by slight changes in methods of cutting and handling timber. The work of two or three species of Ambrosia beetles was also observed in the wood sent from St. Louis, and that observed in West Virginia.

SCOLYTID INJURIES 'TO WHISKY AND VINEGAR BARRELS.-My attention has recently been called to the fact that some insect boring in the staves of whisky and vinegar barrels causes considerable loss from leakage. The character of the specimens of work I have examined indicates that this trouble is caused by species of the genera Xyleborus and Monarthrum.

BUPRESTID LARVA DESTRUCTIVE TO LIVING WHITE PINE TIMBER.On Decemer 1, 1897, while making some investigations in the white 
pine forests near Crow, Raleigh County, I found that portions of the trunks of some of the largest and finest looking white pine trees were rendered worthless by the work of a large Buprestid larva, which had entered the living wood from eggs deposited in slight wounds in the bark. They mine in all directions through the heartwood, causing it to become completely honeycombed, and finally resulting in the total destruction of the heartwood from decay. Some full-grown larva and fragments of an adult were found which were sufficient to identify it as a very large species, probably closely allied to Chalcophora virginiensis. The large woodpecker, Campephilus principalis, appears to be fond of the larvæ, since in some living trees infested by this insect I found large, square holes, some of them 3 by 5 inches at the surface and 5 inches deep.

Periodical cicada, Cicada septendecim.-The appearance of a swarm of Brood XV over the larger part of the State in May and June, 1897 , enabled me to obtain much additional information regarding the distribution of this and other broods in the State. It appears from such data as I have collected that we have at least eight broods in West Virginia, namely: Broods XV, XVII, XX, XXI, XXII, V, VIII, XI. It was also found that the Cicada did far greater harm to old apple trees than was heretofore supposed, owing to the wounds made by the female in the terminal twig failing to heal, also to the fact that the woolly aphis often inhabits the wounds and prevents them from healing, both on young and old trees. ${ }^{1}$

Some evidence derived from the study of the phenological features as related to the periodical Cicada, and certain widely distributed forest trees, makes it seem probable that the dates of the periodical appearance of the different swarms of the Cicada is governed by the same phenological laws as those governing the periodical phenomena of plants. Consequently, the first general appearance of the insect in any given locality will probably correspond closely to the first general appearance of leaves and flowers on certain plants, as with the first flowers of the yellow or black locust, tulip tree, wild cherry, ete.

I was also led to conclude from a study of phenological and temperature $\mathrm{da}^{+}$a that there is quite a uniform period of three to four days difference in the periodical phenomena of insects and plants for each degree of difference in the normal temperature of April to September, inclusive, between two or more near by or distant places.

This evidence led to a study of the temperature data of this and arljoining States, and especially that relating to the Appalachian province, in order to determine the rates of difference in normal temperatures at different elevations and degrees of latitude.

From the information thus obtained, I formulated rules and tables for the approximate determination of the sum of heat, or normal temperature of the season of growth and reproduction at any place in the 
State, without the aid of meteorological instruments. By comparing the normals obtained by this method with those recorded at our princi pal meteorological stations it has been shown that where the local conditions are similar there is but very little difference between the estimated and recorded normals. Indeed, it is believed that the normals obtained by this method are quite as useful in furnishing evidence for the determination of life zone areas and boundaries as is voluntary meteorological data, which at best is far too meager for the purpose, and often entirely unreliable. The method I have adopted for estimating the normal temperature of a place may be briefly outlined as follows:

The recorded daily temperatures, or sum of heat, from April to September, inclusive, for a long series of years, at a given meteorological station at the southern boundary of the State, is reduced to sea level by adding the degrees of temperature due to altitude. The normal temperature of the same period at any other place in the State is then taken to be equal to the degrees of temperature due to the elevation of the place above sea level and the degrees and minutes of latitude north of the station, minus the reduced normal. This gives an approximate normal, which may be subsequently corrected for local influences of soil, exposure, river valleys, etc., by phenological and biological records compared with similar records at another place of known normal temperature. The table I have prepared, to show the calculated, or estimated, normals for each 200 -foot contour of elevation in belts of $15^{\prime}$ of latitude across the State between latitudes $370^{\circ} 1 \tilde{5}^{\prime}$ and $40^{\circ} 4 \tilde{5}^{\prime}$, presents some interesting evidence of the normal temperature of different sections of the State and the range and boundaries of the life zones, so far as determined by laws of temperature. It indicates that the normal temperature of the season of growth and reproduction in West Virginia ranges from $69.4^{\circ}$ at the lowest southern elevations to $53.3^{\circ}$ at the highest elevations. It also shows that the boundaries between the several life zones do not follow regular contours of elevation, but so far as determined by temperature, they rise southward at an average rate of about 100 feet for each $15^{\prime}$ of latitude.

In the discussion of this paper Mr. Smith called attention to the fact that in the use of kerosene Mr. Hopkins's experience conformed with his own in New Jersey and was quite at variance with those obtained by Mr. Johnson in Maryland. He suggested the setting aside of an hour for the discussion of the subject of the use of kerosene. No action was taken, but an informal discussion followed, participated in by Messrs. Johnson, Alwood, Sinith, Marlatt, Osborn, and Howard. The discussion was of considerable importance, and a statement has been obtained from most of the participants, detailing their remarks substantially as given, as follows:

7184-No. $17-4$ 
$\mathrm{Mr}$. Alwood stated that he had used kerosene for two years, spraying it upon the plants undiluted, and his results have, in the main been very satisfactory. Where he used it himself with proper caution he never killed a plant of any kind; and in most cases where he advised others to use it the results have been very good, with few exceptions. One of the most marked of these exceptions he had happened to examine immediately after the treatment had been completed, and the trees had been completely drenched with the kerosene, so that it flowed down the trunks in quantity; the result was that the trees were killed. These trees consisted of about twenty full-grown bearing peach trees and three pear trees which had been two years set. The treatment was applied in the fall just as the foliage was maturing. In one notable instance, a fruit grower applied the kerosene under his instructions to several hundred Japanese plum and Kieffer pears in the spring just as the buds were beginning to open and not a tree was killed or perceptibly injured, yet the San Jose scale was almost entirely destroyed by the one application. On part of these trees the treatment was repeated about two weeks later when they were coming into bloom; yet no harm resulted from this second application. Where the second application was given he had for the past two seasons been unable to find a live scale. During the past spring he had had treated under his direction, but not by trained men, a large number of premises, including small house grounds and orchards of considerable size, with the result that at this date not a single case where the trees were killed has been reported to him. On the contrary, every report has been favorable. The applications were made during the entire spring, beginning when the trees were still dormant and continuing until they were in full bloom, and included all varieties of fruit trees, pears, peaches, plums, and apples. In some cases the treatment was applied purposely when the trees were in full bloom to see whether it would have any effect upon the setting of the fruit or upon the trees themselves. The man who had done this work reported that up to the present time absolutely no harm had been done to the trees, and part of them had been inspected by Mr. Alwood, and he was unable to discover any injury whatever. In Montgomery County and at the Virginia Polytechnic Institute, he had a large number of trees treated both with pure kerosene and with dilutions ranging from 15 to 50 per cent kerosene, and where the application has been made with proper weather conditions and in a cautious manner, no harm has resulted; but where he purposely had the work done in dark or stormy weather, or had the application repeated either the same day or within a few days, the result had been harmful, and in some cases the plants have been destroyed. But in all the work that has come under his personal observation, including all classes of fruit trees, where the applications have been made in a properly atomized spray under proper weather conditions, no injury has resulted, and the San Jose scale has been, as a rule, destroyed by the one application. In fact, he 
could not remember any case in which the spray had been applied under his personal direction where it had failed to destroy the scale. The applications in his work have been made with a blast atomizer, such as is illustrated in his bulletin, No. 74, of the State experıment station of Virginia, or with the Deming pumps, using their mixing apparatus for the diluted applications, and for the pure applications the Vermorel nozzle, with one-twentieth-inch aperture. He added that in one instance he had an entire nursery sprayed with kerosene early in the present summer, and that no harm resulted except to a few rows where a storm came up before the kerosene had evaporated. These were somewhat burned, but at this date the fact can not be noticed, and the stock is in as good condition as the rest of the nursery. He intends pushing work with pure kerosene the coming fall and winter.

Mr. Smith said that his experience since the last meeting in the use of kerosene had been, on the whole, extremely favorable, many barrels of the material having been used in New Jersey during the winter of 1897-98, and in general with very good success. One correspondent sprayed his entire orchard once in January, and part of the worst infested trees had been sprayed the preceding September. The twice treated trees were pears, and they bore a fair crop this year, while the scales were so reduced in number that only a few could be found during September of this year. Several hundred peach trees were sprayed in Jannary, and these included trees that had been set out in the spring of 1897 , and all ages from that up to bearing trees. Of the bearing trees none were injured, and they bore a full crop this year. The trees are in excellent condition as a rule, although there has been considerable rot and some yellows. The scale is still present on some trees, but there has been a very general reduction, and he has advised against making any treatment on these trees d uring the coming winter, since the scale can not increase next year to such an extent as to harm them. A large orchard of pear trees covering 8 acres solid had every tree sprayed thoroughly with undiluted kerosene, and it had a full crop this year, and no trace of injury done by the oil. Of the one-year old peach trees that were sprayed, about one-half of the Mountain Rose were killed, but no other variety was affected, so far as could be seen. An orchard of 2,000 peach trees, thoroughly encrusted with the scale so that it had begun to die, was drenched with kerosene during the winter and all the trees were killed; but the farmer himself in this case says that he is quite as ready to charge the scale as the kerosene with this effect. He has seen absolutely no reason to change the recommendations that he had previously made. He yet believed that the proper use of kerosene is one of the best measures that we have at our disposal, but he was not ready to say that it is the best. He was strongly inclined to believe that he had found something better and less likely to be harmful in actual use.

Mr. Marlatt stated that the tests with pure kerosene made by him and reported at the previous meeting of the association had been 
repeated during the winter of 1897-98, the applications being made under different weather conditions. In no case had any damage resulted except in the first test, which was conducted on a still day with a very moist atmosphere, the sun breaking through the light fog which prevailed. The trees included peach, apple, pear, and quince, and it was noted that the bark gave evidence of being oily and remained dark colored for a long time, the oil seeming to have soaked in, and did not readily evaporate afterwards. The peach trees included in this first test were all killed to the ground, the apple, pear, and quince trees sustaining no damage whatever. Later tests in bright weather on the same varieties of trees and also on cherry trees did not develop any injury to any of the trees, not even the peach suffering in the least. In this instance, however, the wet or oily appearance of the bark was not noticeable as in the former instance except for a short time after the treatment. He referred to the experience of former years in which diverse results had been obtained, and was inclined to adhere to the ground taken in 1897, namely, that treatment with oil is dangerous and liable to kill the trees or greatly injure them, and its use should never be recommended without calling attention to this possibility and leaving the grower to undertake the work at his own risk.

Mr. Osborn reported that his experience with pure kerosene as an insecticide was too limited for him to express a decided opinion. From the difficulties cncountered in getting a uniform spray in case of windy weather and the varying rapidity of evaporation during different degrees of humidity it would seem as yet unsafe to recommend it generally. In future experiments it would seem desirable to keep careful records of humidity, temperature, wind, and the particular species of plants sprayer, so as to arrive at some sure foundation in case it proves safe under certain conditions. Even then there would be danger that the average orchardist would not be so careful in securing the necessary conditious as might be required to secure safe results.

Mr. Howard stated that in view of the diverse experiences given by different speakers, and also shown in the literature of the subject, he felt that the recommendation that he had made in Bulletin No. 12, Division of Entomology, on the San Jose scale in 1896-97, was still pertinent, namely, that it is not advisable to recommend the pure kero. sene spray as the result of any one's experience without first advising the individual fruit grower to experiment in a small way and determine for himself by experience in his own locality and under the local conditions that exist there whether he can use kerosene to advantage.

Mr Johnson stated that his experience with pure kerosene in Maryland was such that he could not recommend it for spraying young and bearing trees in the orchard, unless done under his own personal supervision. Even then, he said, he would use the material with reluctance, as he felt sure he was using a substance more disastrous to the life and vitality of a tree than the San Jose scale itself. In all the experi- 
ments conducted in that State with pure kerosene on bearing trees, the tree had either been killed or injured, or the fruit buds had been destroyed. He cited an instance where 132 nine-year-cld Buffum pear trees had been sprayed during the middle of January, 1898, with pure kerosene in the hands of an expert, and that the entire block had either been killed outright or injured to such an extent that they have since been dug up and burned. He presented a photograph which was taken May 24, 1898, of one of these trees. It was as free from foliage as a tree in midwinter. Other photographs were presented showing trees which had been seriously injured by the use of pure kerosene, and which had been cut back to the trunks. In striking contrast with these, still another photograph was presented showing one of these trees, which had been sprayed with whale-oil soap at the rate of 2 pounds per gallon of water, in full foliage and heavily set with fruit. Mr. Johnson also stated that still another block of thirty-year-old Duchess pear trees had been sprayed at the same time and under the same conditions, none of which were killed, but at the same time all the fruit buds were destroyed, and the development of the foliage greatly retarded in the spring. Other trees in the same block which were not sprayed with kerosene contained a full crop, and it was a very easy matter to ascertain at a glance the very tree where the kerosene spray had been exhausted. In every instance, bearing trees, whether sprayed the "middle of a September sunshiny day," in midwinter, or spring, from 50 to 100 per cent of the fruit buds had been killed, and the vitality of the tree more or less affected, if not killed altogether. Where pure kerosene had been used upon peach and young plum trees, and in all cases with pear and apple, the growth had been considerably retarded, the peach having been so seriously injured it was necessary to cut back all the branches to the main trunk. The peach and pear were so seriously injured that they made but a very feeble growth during this season and stand in striking contrast with other trees by their side which were sprayed at the same time with whale-oil soap at the rate of 2 pounds to a gallon of water.

Summing up the results of his experiments in Marylaud, Mr. Johnson stated that it seemed certain (1) that pure kerosene can not be safely recommended in Maryland as a spray for young and bearing orchard trees at any time of the year; (2) that very old trees of certain varieties, such as the Duchess pear, resisted the destructive effects of pure kerosene more than other bearing trees, such as Buffum, a condition no doubt due to the fact that the wood of the very old varieties is harder and more matured, thus resisting the penetrating properties of the kerosene; (3) that from 80 to 100 per cent of the fruit buds are killed on the bearing trees, whether sprayed in the fall, midwinter, or spring; (4) that young trees, especially peach and plium, are seriously injured or killed; (5) that pure kerosene emulsion or kerosene diluted can not be safely recommended until further experiments are conducted. He further 
stated that from what he had seen of the effects of pure kerosene upon fruit trees, he would advise the fruit growers, especially of Maryland, to avoid the use of mineral oils. He said Captain Emory, one of Maryland's largest and most successful fruit growers, had been persuaded to spray his Buffum and Duchess pear orchards with pure kerosene upon recommendations made in Bulletin No. 125 of the New Jersey Experiment Station, which he received in January, 1898. Captain Emory asked his (Mr. Johnson's) opinion regarding this treatment, and was strongly urged by him not to spray the entire block, but to limit his experiments to a half dozen trees and see the results, and be his own judge as to the efficiency of this method for the destruction of the San Jose scale. Instead of using a few trees, as advised, 132 trees were sprayed, and the results were so conspicuous he was of the opinion that this ocular demonstration [presented photographs] ought to be sufficient for the most skeptical. Captain Emory assured him that if it had not been for his appeals to him not to spray with kerosene, he would have killed his entire orchard, and thus lost several thousand dollars in fruit, as the trees not sprayed were this year laden. He said it was needless for him to say that this experience was sufficient for one of Maryland's most enterprising fruit growers, and that Mr. Emory was now thoroughlý convinced that pure kerosene sprayed during the "middle of a sunshiny day," in the "finest possible mist," in the hands of an expert, is surer death to certain trees than the San Jose scale.

Mr. Johnson also called attention to the reference Dr. Smith had made in his report for 1897 , to the pear trees he had sprayed with pure kerosene September 30, on Captain Emory's place. Dr. Smith had seen these trees about fifteen days after they had been sprayed, and reported that they were none the worse for the treatment. Such a report was misleading. While it was true that the foliage and the tree, so far as it looked in the fall, was not seriously injured, nearly all the fruit buds had been killed. The tree sprayed in the morning had only 7 pears, the one treated at midday 11 , and the one in the evening 17 , while those surrounding, sprayed with whale-oil soap and fumigated with hydrocyanic acid gas, were laden with fruit. The pears on two trees were counted; one contained 214 and the other 197 . These pears were extra fine Bartletts and were valued at one-half a cent each. The iruit, therefore, on one tree was worth $\$ 1.07$, while the other was estimater at 98 cents. The difference between the value of the fruits upon those sprayed with kerosene and those sprayed with whale-oil soap or fumigated was enough to have purchased the soap or cyanide for 25 trees. Mr. Johnson, who had with him photographs of these trees, said he did not think it good policy to report upon such experiments too soon, as such statements were very often misleading. He did not see any advantage in using pure kerosene anyway if 50 per cent kerosene and water would destroy the scale. He said he was now using kerosene diluted one-half with water in Maryland as a sum- 
mer wash against the scale. As yet he had not noted any serious results to the vitality of the tree or to the fruit buds; but he empha. sized the fact that he was not recommending this treatment to the fruit growers of Maryland or any other State.

Dr. Howard presented the following paper:

\section{NOTES ON HOUSE FLIES AND MOSQUITOES.}

By L. O. Howard, Trashington, D. C.

[Author's abstract.]

The speaker referred in some detail to the experimental work against the house fly which he has been carrying on at Washington for the past two years, the results of which had just been published in Circular No. 36, second series, Division of Entomology, United States Department of Agriculture. He also described at some length the experiments against mosquitoes which had been conducted on a large scale the past summer under the supervision of his office by some of the members of the Richmond County Country Club on Staten Island, N. Y. Referring to the widespread publication during the year of a recommendation of pẹrmanganate of potash as a mosquito remedy, he said:

"One of the mosquito developments of the year has been the extensive publication in all sorts of newspapers of an item (usually credited to the Public Health Journal) which reads as follows:

"Two and one-half hours are required for a mosquito to develop from its first stage, a speck resembling cholera bacteria, to its active and venomons maturity. The insect in all its phases may be instantly killed by contact with minute quantities of permanganate of potash. It is claimed that one part of this substance in 1,500 of solution distributed in mosquito marshes will render the development of larvæ impossible; that a handful of permanganate will oxidize a 10 -acre swamp, kill its embryo insects, and keep it free from organic matter for thirty dars, at a cost of 25 cents; that with care a whole State may be kept free of insect pests at a small cost. An efficacious method is to scatter a few crystals widely apart. A single pinch of permanganate has killed all the germs in a 1,000-gallor tank.

"The item is so obviously ridiculons upon its face that it would hardly seem worth while to make any attempt to refute its statements. Nevertheless, it has been so widely read that definite experimentation seems necessary to set the matter at rest. The unknown author's ignorance of the life history of mosquitoes in the opening sentence need not necessarily imply that he would not know a good remedy if he found one. Careful experiments were undertaken in July with various strengths of permanganate of potash in water containing mosquito larvæ from one to six days old. It was found that small amounts of the chemical had no effect whatever upon the larvie, which were, however, killed by using amounts so large that, instead of using' a 'handful to a 10-acre swamp,' at least a wagon load would have to be used to accomplish any result. Moreover, after the use of this large amount and after the larvæ were killed, the same water twenty-four hours later 
sustained freshly-hatched mosquito larvæ perfectly, so that even were a person to go to the prohibitive expense of killing mosquito larvæ in the swamp with permanganate of potash, the same task would have to be done over again two days later."

Mr. Smith, referring to the use of kerosene as a means of controlling the mosquito on Staten Island, stated that the botanist, Dr. Britton, had entered a complaint against the use of this oil on the ground that it was very destructive to all water plants. Referring to the possibility of mosquitoes being carried by strong winds to considerable distances, he stated that he had noticed that they would not rise or take flight when a brisk breeze was blowing, and even a comparatively slight breeze will keep them from upper stories of houses. He therefore doubted the wide distribution of mosquitoes by high winds.

Mr. H. T. Fernald gave an experience with mosquitoes at Coldspring Harbor, Long Island. He stated that with a north breeze there were no mosquitoes; with a south breeze, on the other hand, they were often very troublesome, especially after a prolonged gentle wind of five or more hours duration. There were no pools on the center of the island, and the mosquitoes were supposed to have been carried from the south shore, a distance of some 15 miles.

Mr. Hopkins stated that the reference to the so-called ring-legged mosquito breeding in saline swamps, reminded him that among the hills near Morgantown there occurs a similar mosquito which apparently breeds in pools and small streams fed from coal-mine drainage, the water of which contains a large per cent of sulphate of iron. He suggested that this sulphur water might offer farorable conditions for this mosquito, which is quite common in the neighborhood of such waters. $\mathrm{He}$ also stated that since an extensive pumping station had been located near the river bank where the oil-pipe line crosses, a mile above Morgantown, the oil frequently escapes out over the river and is apparently the cause of the city being almost exempt from mosquitoes during the past ten years.

Mr. Osborn described the mosquito conditions existing at the agricultural college at Ames, Iowa. He stated that in dry seasons the small pools within a quarter to half a mile of the college building dried up and the mosquitoes disappeared, in spite of the fact that within about a mile there were large pools which never became dry.

Mr. Howard, referring to the instance of mosquitoes breeding in water coming from coal mines, eited by Mr. Hopkins, mentioned having received the larvæ of an Ephydrid fly from Los Angeles, Cal., which breeds in pools of waste petroleum about the oil wells in that vicinity.

Mr. Smith asked if it were possible for the mosquito to breed in mud, and suggested that there was no reason to believe that the actual presence of water was necessary for all mosquito species. Mr. Howard thought that such possibility was doubtful. 
Mr. Howard described a scheme suggested by Mr. W. C. Kerr for disseminating oil over the marshy tracts to be treated on Staten Island, namely, by putting in barrels of oil in winter when the ground was frozen and piercing the barrels with small holes so that the oil would escape slowly throughout the breeding season.

Mr. Howard presented the following paper:

\section{PULVINARIA ACERICOLA (W. \& R.) AND P. INNUMERABILIS RATHV.}

By L. O. Howard, Washington, D.C.

Every one interested in ecoliomic entomology and in the Coccidx will remember the Walsh and Riley figure on page 14, Vol. I, American Entomologist (fig. 3), which gives at $b$ a drawing of Lecanium maciurce n. sp., which represents a Pulvinaria upon a branch of Osage orange, and at $a$, Lecanium acericola n. sp., representing a Pulvinaria upon a leaf of what is apparently silver maple. There is almost no de scriptive matter concerning the Lecanium acericola, but the figure is a clear, sharp one, and, as events have shown, it is quite distinctive. The lamented J. Duncan Putnam, in his admirable paper on Pulvinaria innumerabilis, published in Vol. II, Proceedings of the Davenport Academy of Natural Sciences, in 1879, considered Lecanium

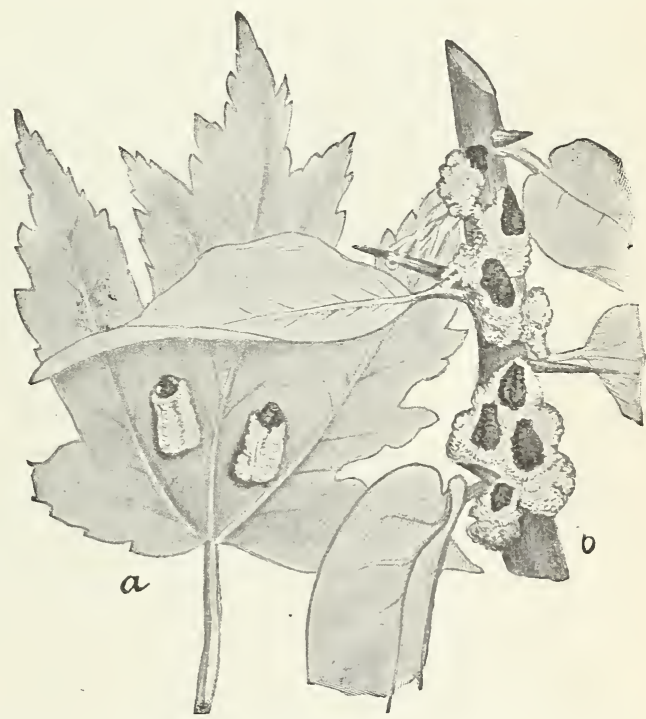

FIG. 3.-a, Pulvinaria acericola (W. aud R.) on leaf of silver maple; b, Pulvinaria innumerabilis Rathr. on twig of Osage orange-natural size (redrawn from Walsh and Riley).

acericola to be a synonym of $P$. innumerabilis, while Lecanium maclurce he considered a possible synonym.

Miss Emily A. Smith, in her paper entitled "The maple-tree barklouse," published in Vol. XII of the American Naturalist (1878), questions the accuracy of the Walsh and Riley figure of the insects upon the leaf of maple, but the idea that the species is different from $P$. innumerabilis, the common twig-inhabiting form throughout Northeastern United States, does not seem to have occurred to her. Dr. S. S. Rathvon, however, who originally described $P$. innumerabilis in 1854, writing to Mr. Putnam about 1879, stated that he had all along 
been impressed with the belief that there are two species of Pulvinaria to be found upon the maple tree, the form occasionally found upon the leaves being not so large, the secreted cotton mass somewhat depressed, faintly bilobed, and transversely undulated or indented.

The receipt during June of the present year (1898) of specimens of a Pulvinaria on the leaves of a silver maple from Prof. Hunter Nicholson, of Knoxville, Tenn., and which plainly differed from P. innumerabilis, and resembled at the same time perfectly the Walsh-Riley figure of Lecanium acericola, induced the writer to search for the original specimens in the old Riley collection. They were found, and the accuracy of the figure in the American Entomologist was perfectly established; the identity of the species received upon leaves from Knoxville, Tenn., with the American Entomologist figure was also established, and that the insect is specifically distinct from Pulvinaria innumerabilis Rathvon was withont difficulty ascertained. The description by Walsh and Riley, as has already been stated, was inadequate, yet the accurate figure amply suffices to carry the name, and this smaller leaf-inhabiting Pulvinaria must in future be known as Pulvinaria acericola (Walsh and Riley), its known habitats being Davenport, Iowa; — Indiana (B. W. McLain), $c f$. American Entomologist, Vol. II, page 14; Lancaster, Pa. (Rathvon), and Knoxville, Tenn. (Nicholson).

The writer has the species under daily observation at Washington, and expects at an early date to publish its full life history, which must present some interesting variations from that of $P$. innumerabilis.

The paper was discussed by Mr. Hopkins, who referred to a species occurring on the yellow locust in West Virginia.

Mr. Smith stated that he had been puzzled with these insects and that in New Brunswick, this season, the only species present was the one occurring on the leaves.

Mr. Howard referred to the great range of Pulvinaria innumerabilis, extending from the Mississippi Valley eastward, and commented on the inaccuracy of the old records.

The committee appointed at the last session to nominate officers for the ensuing year presented the following names:

For president, C. L. Marlatt.

For vice-president, Lawrence Bruner.

For second vice-president,C. P. Gillette.

For secretary-treasurer, A. H. Kirkland.

The persons nominated were duly elected to the offices named.

On motion, an evening session was determined upon to begin at 8 o'clock. 
EIENING SESSION, FRIDAY, AUGUST 19, 1898.

The first paper of the evening was presented by Mr. A. F. Burgess, as follows:

\section{AN ABNORMAL COCCINELLID.}

By A. F. Burgess, Malden, Mass.

The economic importance of scale insects and Aphids is correlated with that of the Coccinellids, a group which furnishes the chief checks upon their increase. The introduction of the Vedalia cardinalis and allied species into California will illustrate the benefit derived from an accurate knowledge of the habits of these predaceous beetles, and a thorough study of the food habits of our native ladybirds probably would show that they are the chief agencies controlling the increase of many of our indigenous scale insects, and without their assistance these insects might prove highly injurious.

Our most common Coccinellid, Adalia bipunctata, plays an important part in checking the undesirable increase of certain Coccids and Aphids in this region, and an interesting fact concerning this species, noted during the present season, may be recorded properly at this time. On April 13 while collecting in the Middlesex Fells, Malden, Mass., I took a pair of ladybirds in coitu on a white birch upon which Aphid eggs were thickly massed. An examination of the specimens showed the female to be a normal Adalia bipunctata, while the male was black in color with a blood-red marking at the humeral angle of each elytron; posterior to each of these markings was a small dot of the same color. The beetles were fed upon Aphid eggs at the insectary, and upon April 20 the female laid a cluster of fourteen eggs, followed by another of eight eggs on April 23. These lots of eggs hatched in four and seven days, respectively. 'The larvæ were fed upon Aphids, and from the material left after the preservation of specimens two imagos were reared, both being of the blavk form. The male parent insect was placed with a female Chilocorus bivulnerus on May 3, but, as expected, died without mating. The female Adalia continued to lay up to June 1, the eggs, with the exception of the last four clusters, proving fertile. Many of the larvæ died before completing their transformations, and only a single black adult was reared.

On May 5 another pair of these insects were found in coitu near the place where the first pair was taken, and in this case the male was of the black type, the female being a normal Adalia. From eggs deposited by this female there were reared two beetles of the black form and an Adalia of the normal color and form. These three insects were placed in a jar with the three beetles from the brood previously mentioned. On June 15 two of the black form were found pairing, the eggs subsequently laid prover fertile, but the larvæ died before reaching maturity. June 26 an Adalia male and a black female (both belonging 
to the above lot) were found mating, and from eggs laid by the female there have been reared ten typical Adalias and four of the black form.

The latter seem to correspond closely with Coccinella humeralis Say, which was described from two specimens taken near the Rocky Mountains. Le Conte, in his edition of Say's writings published in 1859, states that this species is unknown to him, and probably for this reason Mr. Henshaw does not include it in his list of the Coleoptera.

I am unable to decide whether the black form is an abnormal Adalia or represents a distinct species. Against the ground that it is an abnormal or "sport" Adalia may be placed the continuity of this form through two generations. If the preceding was the case it would seem that in the progeny of this form there would have been a greater reversion to the Adalia type. On the other hand, if the black form represents a distinct species, we have clearly a case of hybridization, resulting in the product of fertile hybrids. In insects, hybrids generally partake of the characters in size, form, and color of both parents. In this case the progeny of these mismated insects do not show any blending in these respects. The black forms are duplicates of the black pareuts and the Adalia are of the normal Adalia type.

[Since presenting this paper Dr. John B. Smith has kindly compared the black form with specimens in the Horn collection at Philadelphia. He says: "I find in that collection a number of specimens, some of them resembling yours closely, some differing in details and marked Adalia bipuncta var. humeralis Say. The localities represented in this series are Minnesota, Arizona, California, Colorado, Utah, and Oregon. You will see, therefore, that the form is widely distributed, and, in fact, occurs wherever the type occurs." I have also, through the courtesy of Mr. Samuel Henshaw, examined the specimens in the Le Conte collection at the Museum of Comparative Anatomy at Cambridge, Mass. I find several examples of the black form placed in company with examples of Adalia bipunctata and labeled C. humeralis Say.

Thus it appears that we have here a strongly marked variety, which retains its characters even when inbred with typical forms of the species. So far as I can learn, the inbreeding of these forms has not been recorded heretofore.]

This communication was discussed by Messrs. Howard and Smith, the latter referring to the value of genitalia of insects as a means of separating species or groups of species, stating that in some genera these characters have no value whatever, while in other genera the characters found might be absolutely relied on as indicating specific differences. He said that a difference in genitalia always means a different species, but a similarity or identity in genitalia does not necessarily mean the same species. He believed the black form 
described by Mr. Burgess to be the normal black dimorphic female of the species.

Referring to the feeding of the species on the San Jose scale, he stated that this record was important as showing that our native species may do the work which it was desired to accompiish by the importation of foreign predaceous insects.

Mr. Cooley read the following paper:

\section{NOTES ON SOME MASSACHUSETTS COCCID压.}

By R. A. Cooley, Amherst, Mass.

The "maple leaf-louse," Pseudococcus aceris, continues to be a serious enemy to street maples in this State, and a brief account of our experience with it may be of interest to the members of the association. The worst infested locality which has come under my observation is the one in Springfield, although another in Holyoke is scarcely less important. The authorities of Springfield have been fighting this insect ever since their attention was called to it a number of years ago, but their efforts have been attended with only partial success. During the winter of $1895-96$ the trunks of the trees were scraped smooth and treated with a concentrated solution of whale-oil soap, applied with whitewash brushes. Visiting the locality on April 9, 1896, the writer gathered specimens on pieces of bark from the trees and took them to the insectary, where they were examined and all found to be dead. It seemed certain then that the insect was well under control, but by fall it had again multiplied to destructive numbers. The treatment was repeated during the winter of 1896-97, but, if the writer is correctly informed, the insects were more abundant than ever the next summer. Last winter the trees were under the care of Mr. W. F. Gale, who has been appointed city forester in place of Mr. Clark, who previously held the position. Mr. Gale treated the trees with an insecticide prepared as follows: Three pounds of whale oil soap were dissolved in 3 gallons of hot water, and to this solution was added 1 gallon of kerosene. This mixture was churned till an emulsion was formed, after which 2 drams of crude carbolic acid were stirred in. Before applying the emulsion it was diluted with an equal part of water. The writer examined the trees on July 20 and again on August 6, and could find comparatively few specimens of the insect and the trees appeared to be perfectly healthy.

Quite in contrast to this experience in Springfield has been that of Mr. D. H. Newton, city forester of Holyoke. Mr. A. V. Capen, Mr. Newton's foreman, informed the writer that in February of 1896 the infested maples in Holyoke were sprayed with whale-oil soap solution, 1 pound of the soap in 1 gallon of water, and that since that time the insects had never been abundant enough to require treatment. 
While the writer does not attempt an explanation of the difference in results obtained with the same insecticide in the two cities, it is possible that one may be found in the fact that the insecticide, being applied as a spray to the the trees in Holyoke, reached more of the limb surface and killed a greater percentage of the insects than did the application with whitewash brushes in Springfield.

At the time of the writer's visit to the trees in Springfield on July 20 the adult females were laying eggs and a part of those laid had already hatched. The young lice, however, had not migrated far, being still clustered around the parent insect. In the cottony masses enveloping the eggs and crawling about over the leaves and branches were great numbers of the larvæ of the Coccinellid beetle, Hyperaspis signata. These larvæ were feeding voraciously on the eggs, larvæ, and adults of Pseudococcus aceris. Fully 75 per cent of the cottony egg masses which I saw contained either a larva or a pupa of the beetle or had been devastated and abandoned. Dr. Howard has already recorded this beetle as an enemy to Pseudococcus aceris in Insect Life, Vol. VII, page 239. Desiring to learn if the beetle had appreciably reduced the colony of the Coccid, the writer paid another visit to the city on August 6 , as has already been stated, and found that a remarkable change had taken place. A majority of the trees had only here and there an infested leaf, while others showed no signs of the insect whatever.

The "imported elm bark-louse," Gossyparia ulmi, is a very widely distributed and well-established enemy to elms in the State, ranking in importance second to none, with the possible exception of the San Jose scale. It is a noticeable fact that as common as this insect is in Massachusetts, with very few exceptions it has never been sent to the experiment station at Amherst. An explanation of this may be found perhaps in the fact that the species, being fixed to the bark and somewhat resembling the lichens on the tree, bears but little resemblance to what the ordinary observer recognizes as an insect. Were legs and antennæ visible, and did the creature move, without doubt it would more often be recognized as a pest.

This difficulty in detecting the insect is obviously an important factor in the problem of its control. It is often the case that a tree or row of trees infested with the species is known to be turning yellow or losing here and there a limb, while the owner sees no cause for the damage and takes no action. Meanwhile the trees are being destroyed and the pest is spreading. Precisely these conditions existed in a block of a number of thousands of elms in a large nursery located at Concord. The owner was aware that the trees were in a sickly condition, but did not know the cause, until the writer, visiting the nursery, called his attention to this insect, which was there in great numbers.

As has been stated by many authors, trees previously weakened by other causes are more liable to be attacked by this insect than those which are heaithy. The writer has observed that trees located in the 
heart of a city and fighting against unnatural conditions are sometimes conspicuously attacked. On the grounds of the Massachusetts Agricultural College, Camperdown elms and Scotch elms have been found particularly susceptible to the inroads of the pest. One Camperdown elm has already been destroyed and others have required attention each year.

In a number of instances there have been serious outbreaks of the louse in nurseries in the State. One notable case, that at Concord, has already been referred to, and others equally important might be cited.

While it very often occurs that the insect becomes established and causes injury before its presence is detected, in the experience of the writer it is not a difficult pest to subdue when it is discovered. Kerosene emulsion and whale-oil soap solution have both been used with entirely satisfactory results. A medium-sized American elm infested with the species was sprayed with kerosene emulsion, one part in nine parts of water, early in August, 1896. The young lice had begun to hatch about the middle of July and had continued to appear until near the end of the month. With a view to killing all the insects with one application of the insecticide, the tree was not sprayed until all had appeared. Since the time of the application the tree has been examined repeatedly and only a single living specimen has been found. In June of 1897 the writer's attention was called to a row of elms in Amherst which were very thickly covered on the trunks and lower limbs with the over-wintered females of this insect. Whale-oil soap solution, 1 pound of the soap in 2 gallons of water, was applied, a large paint brush being used for the purpose. Only a few individuals survived the treatment, and the trees are in a good healthy condition this season.

Wishing to obtain duplicate specimens of the species for exchange, the writer removed the bark for about a foot and a half from the trunk of a badly infested tree, about an inch in diameter. Before pinning the bark away it was kept in a glass jar for a time, to see if any parasites would emerge. About a half dozen specimens were procured, a part of which were sent for determination to Dr. Howard, who replied that they belonged to a new species, which I might call Coccophagus gossyparice of his manuscript. So far as the writer is aware, this is the first positive knowledge we have of a parasite on this notorious Coccid.

It is now nearly three years and a half since the San Jose scale, Aspidiotus perniciosus, was first detected in Massachusetts, and that it has gained a firm foothold in the State since that time is evidenced by the large number of localities which are now known to be infested, and by the frequency with which it is received at the experiment station. To the 14 localities which have alieady been recorded in print, Fairfield, Beverly, Dracut, Middleboro, and Natick may now be added. It can hardly be doubted that the pest exists undetected in other local- 
ities, since for a number of years trees were sold to patrons in the State from nurseries which later proved to be infested. In fact, as was recently brought out in Mr. Kirkland's commendable paper on the insect, published in the Massachusetts Crop Report for June, there is great probability that the owners of one of the nurseries of the State have been distributing stock which they knew to bear the scale.

With the single exception of these nurserymen, who have, moreover, allowed a large colony of the insects to remain in their nursery without making any attempt to reduce it, the nurserymen and orchardists of the State have shown commendable energy in their efforts to eradicate the pest, and have no doubt in great measure prevented its spread.

In connection with the foregoing remarks on the San Jose scale, it should be stated that Aspidiotus forbesi and Aspidiotus ancylus, two congeners of perniciosus, now notorious because of their resemblance to that species, have both been found in Massachusetts as well as a third, Aspidiotus fernaldi of Professor Cockerell's manuscript, a species which in some respects very closely resembles the San Jose scale.

Aspidiotus ancylus is a very common insect in this State, occurring on a large number of food plants, and has in a few instances been very injurious. The most notable case that has come under the writer's observation is a young apple orchard in Malden, in which nearly every tree was infested with the species, some very abundantly, while one was dying from the attack.

Aspidiotus forbesi has been found by Mr. Kirkland in a single instance at the Shady Hill nurseries on apple trees received from Geneva, N. Y.

Aspidiotus fernaldi occurs on a row of Honey Locust trees in the Charles Bank Park in Boston. The same trees are also badly infested with Aspidiotus ancylus.

On January 26, 1898, Mr. A. H. Kirkland sent the writer specimens of a scale insect on Prunus mume from the Arnold Arboretum, Jamaica Plain, Mass., which on examination proved to be the new peach scale, Diaspis amygdali. The infested trees were received from Japan in the spring of 1897, and being in an unhealthy condition were planted in an out of the way place, where they had remained for nearly a year previous to the date mentioned, when they were found to be nearly all dead. Specimens of the insect were later sent to Dr. Howard, who confirmed the writer's identification, stating also that Mr. Jack had already sent him specimens which had been determined as Diaspis amyg. dali. Another tree, Prunus subhirtella, received from Japan on April 17,1894 , is infested with the scale, but does not appear to be seriously injured. An explanation of this may be found perhaps in the fact that the tree is located on a sonthern slope where the sun beats down strongly in the early spring, making the spot very warm during the day, while at night it is severely cold. Visiting the tree on March 28 of this year the writer found nearly all of the over-wintered females alive, 
though at a later visit, on June 14, nearly all were dead, the living specimens being without exception on the side of the tree opposite from the sun. The alternating extremes of temperature or some other canse had so reduced the number of adult females that comparatively few young had been developed. If similar conditions have existed since the tree was planted in the spring of 1894 , it is not difficult to understand why it has not succumbed to the attack of the insect.

While these observations show conclusively that this scale can successfully exist in Massachusetts in spite of the rigors of our New England climate, it seems doubtful if the insect will prove a serious pest in this region.

These specimens of Diaspis amygdali, together with others received from various sources, were compared with specimens of Chionaspis prunicola received from Professor Maskell, the author of the species, and found to be identical. The writer therefore considers Chionaspis prunicola to be a synonym of Diaspis amygdali, since the latter specific name has priority.

In the discussion, Mr. Smith, referring to the notes on Psendococcus, said the experience cited was interesting from its contradictory nature, but he questioned if the explanation of the disappearance of the insect in some instances was due to the treatment. He was of the opinion, on the contrary, that it might be from an entirely different cause. He illustrated his ground for this belief by his experience with this insect in New Jersey, where it had disappeared without apparent cause after having increased steadily for three years. He referred to the possibility of clearing them from the surface of the bark by the application of a strong stream of water from a wateriug hose.

Mr. Alwood expressed considerable interest in the report of excessive injury from the presence of Aspidiotus ancylus, and particularly in the fact that a tree had been killed by this insect. He stated that he knew of a tree covered with this scale in Virginia, and that fatal results had not followed. He said that it was a difficult species to determine on account of its variability. He had never known it to be sufficiently numerous to destroy trees, referring particnlarly to its occurrence on apple. He stated that he had often received $A$. forbesi from Georgia, where it was very destructive.

Mr. Johuson remarked that he had also had forbesi from Georgia, receiving it from Mr. Scott. In Illinois he had found this species two brooded, but the specimens received from Georgia indicated a possibility of four full broods in that State. This species, which he said was often mistaken for perniciosus, had been received by him from Mr. Fletcher in Canada and from Mr. Cockerell in New Mexico, and it also occurs in Maryland. It is a very common species on apple, and can always be recognized by the pitted appearance of the bark of au infested twig, $7184-$ No. $17-5$ 
due to the apparent sinking of the scale into the bark. With regard to ancylus, it is widely distributed in Maryland, and he has also received it from Ottawa, Canada. It is often associated with forbesi. Gossyparia ulmi he had recently found in Maryland on old trees growing on the estate of General Myers. The trees had doubtless long been infested and the lower branches had been killed. Pseudococcus aceris occurred in the Allegheny Mountain regions of Maryland, maple trees being quite defoliated in certain streets in Cumberland. He had bred the larva of a predaceous fly (Baccha sp.) from this scale in considerable numbers. In answer to a question, he stated that he had never noted that forbesi was viviparous in Illinois, but that there might be a viviparous form in the fourth brood in the south.

Mr. Alwood stated that he had not yet found forbesi in Virginia, but that specimens coming from Southern States to him both in winter and summer had invariably proved to be viviparous; in fact, he har examined a good deal of material and had never seen an oviparous specimen.

Mr. Howard said that according to Green's generalization the species should be oviparous, since its anal plate bears grouped pores. Referring to the pitting occasioned by scale insects, he stated that this was most notable so far as his observations went in the case of Asterodiaspis quercicola.

Mr. Cooley, at Mr. Howard's request, gave some notes on the occurrence of the latter species in the Middlesex Fells, where it was most generally distributed both on white oaks and swamp white oaks. He had not found it on black or red oak. It occurred also on old English oaks at Medford, indicating its long existence in that region.

Mr. Howard mentioned the fact that it was probably introduced upon the Department grounds at Washington about 1870.

Mr. Kirkland stated that the old English oaks in Massachusetts referred to were from 50 to 75 years of age. He also gave further notes on the occurrence of this species in Massachusetts, and also of Gossyparia ulmi. Referring to the killing of trees by Aspidiotus ancylus, he instanced some plum trees killed by this scale in Massachusetts. He stated that the San Jose scale had been found at Fairfield, Mass., at an elevation of 1,300 feet.

Mr. Barrows stated that Gossyparia ulmi was very abundant on the grounds of the Michigan Agricultural College. He thought it very likely that it was carried from place to place by the agency of "honey dew," which attaches the young lice to flies or other insects. He was very skeptical about scale insects being carried about by birds.

Mr. Johnson called attention to the great injury experienced, especially in parts of western Maryland, from Lecanium niarofasciatum Pergande (MS.). He referred to the driving out of the San Jose scale by honey dew secreted by the pear tree Psylla in a certain orchard in Maryland. 
Mr. Fiske presented the following paper, which had been prepared conjointly by Mr. Weed and himself:

\section{NOTES ON SPRUCE BARK-BEETLES.}

By Clarence M. Weed and W. F. Fiske, Durham, N. H.

During the summer of 1897 a complaint was received at the New Hampshire College Experiment Station of damage done to spruce in northern New Hampshire, supposedly by a bark-beetle which had been identified by Mr. F. H. Chittenden as Dendroctonus rufipennis. In the course of the season two trips were made to the infested region by the writers, and the object of this paper is to give a brief account of the life history and habits of the species and of the damage done.

In company with Mr. Austin Cary, of Maine, a forester of long experience, a narrow strip of primeval iorest in northern New Hampshire, about 10 miles long, was explored. The principal trees of this area were hardwoods, birches and maples predominating, but among them were considerable quantities of black spruce. The dead stubs of the latter species, many of them far advanced in decay, were ample evidence that at some previous time it had formed a much larger percentage of the forest. In the course of the three days that were spent in the woods a great many dead and dying trees were examined, and in almost every case where the bark was still clinging to the trunk the peculiar remains of the Dendroctonus burrows, to be described further on, were discernible.

In spite of the great amount of damage which has been and is still being done, it was quite difficult to find the insect actually at work. The infested trees would retain their green color until the young larvæ had reached their full growth, the beetles in many eases flown, and the space under the bark become so filled with a myriad of the smaller Scolytidæ that it would be impossible to say with certainty to which to ascribe the original attack. On one occasion, however, we had an unusual opportunity to observe the working of the Dendroctonus, and the following is copied with little change from notes actually made in the field:

In the afternoon of August $\tilde{5}$ we came across a group of affected trees, As in those found the day before, they were in various stages of death and decay. On some the leaves would still be dropping, but there would be no sign of the Dendroctonus save the remains of the peculiar burrow already mentioned. Others were in more advanced stages of decay, while a few were still green and apparently healthy, but around their bases would be a fine dust, which seems to be discharged at the very beginning of the burrow, and on the trunks would be the telltale tubes of pitch which guarded its entrance. In one tree in the latter condition the limbs approached near enough to the ground to enable one to climb into it. At a height of about 25 feet the trunk was peeled 
without discovering anything but perfectly sound wood. On peeling downward there was found, 2 or 3 feet below, the beginning of a burrow containing a pair of beetles. They had tunneled completely through the bark, but had barely touched the wood. Continuing operations large numbers of embryo burrows were disclosed, some containing one beetle, some a pair. In a space 15 inches long by 5 wide no less than eight burrows were discovered. They were in all stages of development, from a mere hollowing in the bark containing a single beetle, to a tunnel 2 or 3 inches long, and in these cases, also, there was usually but one inhabitant, though it was not rare even then to find the male still accompanying his spouse.

The egg's were found in groups of four to six, in little cells or chambers in the substance of the bark close to the entrance to the burrow. Continuing down the tree, every stage of development might be observed, until when near the base the parent beetle would be found dead at the end of her burrow, while her progeny were fast approaching maturity and numbers of the smaller Scolytidie were entering the breach thus made to continue the work of destruction. In one or two cases the complete larval excavations were found surrounded by perfectly sound wood, and the following description is taken from a field note: First, a gallery is excavated in the bark, running vertically up the tree for a distance of from 3 to 4 inches, and sometimes making a sharp semicircular turn at the further extremity. At the beginning it is two or three times the breadth necessary to allow the beetle to pass through, but after the eggs are deposited in the tiny cells prepared for them the whole space is filled with bits of wood packed solidly together, and through this mass a tunnel is excavated barely large enough for passage. It is these tube-like structures that are so characteristic and which are so readily identified after the trees are long dead.

The eggs were only found in some of the young colonies in cells near the entrance, but it is evident that they are laid at intervals the whole length of the excavation. The young larve would each start a somewhat crooked mine in a different direction from the cluster of eggs. Sometimes these would coalesce later on and several larve would be engaged in making one broad excavation, filling in the space after them as they progressed. When full grown they would have traversed a distance of from 3 to 4 inches, and the area covered by them would spread out in a fan shape on each side of the parental gallery. The whole space beneath the bark would in some cases be occupied. In others there would be quite large areas of sound wood, but this was being rapidly eaten away by the smaller Scolytids.

That the Dendroctonus is the primary cause of the death of the tree there is practically no room for doubt. That in some cases, at least, they are the first insects to appear in the affected trees is sure, and from the conditions existing in the dead and dying groups, where the insects obviously spread from one tree to another, hardly any other 
conclusion is tenable. The fact of their attacking a single tree in overwhelming force is peculiar, but apparently not inconsistent with the habits of the other species. In a large portion of the territory explored nearly every tree was affected except the youngest and those partly decayed. The explanation of the immunity of the first probably lies in the thinness of the bark, which does not offer sufficient protection for so large a beetle. Why the others are not attacked is not so evident.

As to natural enemies, very few were noticed. One or two species of small Cleridre were observed on the trunks of the dead trees in some numbers, and several species of the larger Braconidie were observed ovipositing there. Some hymenopterous cocoons were found in a burrow believed to belong to this species. Evidence of a fungous disease was also seen. That these insects are sometimes checked by natural means is probable from the fact that the death of the trees has sometimes been attributed to the numbers of little flies that were found under the bark.

If the destruction of all the spruce that has been reported as dying in northern New Hampshire and the adjoining portions of Termont, Maine, and Canada is to be attributed to this cause, the injury done is certainly very great. Mr. Cary reports it as working in numerous localities in New Hampshire north of the White Mountains, in northeastern Vermont, and in Maine as far as the western head waters of the lead River. It is probable that it extends over a much greater area, but within these limits the damage amounts to many hundreds of thousands of dollars. This region, which is mountainous and thinly settled, is largely covered with virgin forest, and in this the insect does the greatest amount of damage. Compared with the white pine which covers the hills and valleys in the more sonthern portions of the State, the spruce is of very slow growth, and the problem of keeping the areas in perpetual forest is a difficult one in any case. It is possible that, as the insect troubles only the older and thicker barked trees, the second growth may be exempt until it is big enough for the harvest, but this is one of the many points that need looking into. The number of broods a year, the extent of the flight of the female, the probability of natural checks, and the possibility of artificial ones, together with a more thorough knowledge of the conditions necessary to a successful attack, are but a few of the points that remain to be worked out in regard to a most destructive pest of one of New Hamp. shire's best possessions.

Mr. Hopkins discussed the paper at length, describing the galleries of the species named and allied species, giving some details of the habits of these insects in spruce and pine in West Virginia. He believed Dendroctonus simplex and rufipennis to be distinct species, but could not determine from the notes given by Mr. Fiske which of these species the latter had in mind. 
Mr. H. T. Fernald gave, not for publication, an informal review of the work in past years in economic entomology in Pennsylvania.

Mr. Howard, in discussion of Mr. Fernald's remarks, said that for many years no reports of damage by the wheat midge had been received at the Department of Agriculture in Washington, and asked for the experience of other members of the association.

Messrs. Smith and Johnson both stated that this insect was very rare, or at least not troublesome in New Jersey and Maryland. Both speaker's, however, reported the great abundance of the Hessian fly the present season in their respective States.

Mr. A. H. Kirkland read the following paper•

\section{EXPERIMENTS WITH INSECTICIDES FOR THE GIPSY MOTH AND BROWN-TAIL MOTH.}

By A. H. Kirklaxd, Amherst, Mass.

[Withdrawn for publication elsewhere.]

Mr. W. B. Alwood presented the following papers:

NOTES ON THE LIFE HISTORY OF THE WOOLLY APHIS OF APPLE.?

(Schizoneura lanigera Haussman.)

By Wм. B. Alwood, Blacksburg, Ta.

[Abstract of paper.]

This well-known species was studied both in the field and in the greenhouse, where breeding experiments were carried on in control colonies. The common observations as to the identity of the root-feeding and stem-feeding individuals were repeated, and the individuals colonized from the roots upon stems and from the stems upon roots with perfect success, and many observations of an incidental nature relating to the ordinary life history of this species were recorded.

The principal object of the breeding experiments was to furnish a record of the generations which occur at this place and to study the winged form and the sexual generation. It was hoped that we might settle the part which the winged individuals play in the dissemination of the species, and whether its perpetuation is dependent upon the sexual generation; also it was desired to make critical observations on the overwintering of the agamic form.

Observations on colonies in the orchard were begun in the autumn, and colonies were also started in the greenhouse on potted plants. Colonies on unprotected stems in the orchard persisted all wiuter, but

${ }^{1}$ This paper was prepared from observations made by the writer and Mr. W. M. Scott while the latter was an assistant in the Virginia Polytechnic Institute. 
much the greater number of the individuals perished. Wherever individuals were protected in the crevices of the wound or under injured bark they persisted over winter, without exception, though suffering great diminution. Practically no mature individuals persisted over winter. It was also noted that whenever bright days occurred for any seriod of time in the early winter, so that the mercury ranged from $40^{\circ}$ to $50^{\circ}$, where full-grown females occurred in the winter colonies they gave birth to young.

The colonies in the greenhouse flourished and continued breeding without hindrance during the entire winter season.

In order to note the normal reproduction in this latitude an overwintered female was taken from the colony on May 5 and colonized upon $a$ potted plant. When taken from the colony she was not full grown, but completed her growth and gave birth to young on the 12th of May. These young were taken as the first generation from the over-wintered agamic female, and on the 30th of May produced young of the second generation. These were likewise colonized for observation and produced the third generation on June 1t. Proceeding in like manner, the successive generations were produced on June 29, July 10, July 19, July 30, August 7, August 17, August 26, September 7, and September 20, reaching with this date the twelfth generation in a direct line from the over-wintered female colonized in the spring.

At this date the individuals in our colonies, regardless of their generation, began to become winged, and winged individuals were produced in great abundance, extending over a period of thirty days. The number of the generation had nothing whatever to do with the phenomenon of becoming winged. Howerer, a considerable portion of the individuals in our colonies showed no tendency to become winged, and quite invariably immature lice removed from any colony where winged individuals were being produced failed to become winged when colonized upon fresh plants. It would appear that the mere fact of disturbance and removal to a fresh host plant sufficed to arrest the tendency to become winged.

The winged individuals remained ordinarily at rest in the colony among the unwinged lice, but they made no attempt to feed. After several days they would become restless and fly away. Attempts to trace them were in every case fruitiess, and we were not able to establish the normal habit of this individual in regard to the production of its young. In no case did we observe them producing young among the individuals of an old colony, and we were unable to locate the young when allowed to breed out of confinement.

Retained in confinement, after four or five days they produced their young, usually four to six, within the space of twenty-four hours. These young proved to be sexual individuals and were quite characteristic in their size, organic structure, and coloration. In the first place, they were beakless, having the mouth parts represented by a triangular, 
bulb-like process. The females were much larger than the males and of a yellowish appearance. The size of the female is about half that of the ordinary agamic female, and the male is about half the size of the true female. They are very obscure individuals, and, so far as we could observe, took very little nourishment if any at all. From the condition of the mouth parts they conld not possibly take other than liquid foodi. They completed their growth in about eight days, passing through four molts, and the female then deposited a single egg, which is about 0.75 millimeter long and ovoid in shape, and of a dark-brown color.

Snch trouble was experienced in rearing the sexual individual that we were not able to make extensive observations on oviposition, nor were we able to carry eggs over to the hatching period to produce a stem mother, but they were carried long enough to conclude that the egg does not hatch in the autumn.

The formation of the single egg can be observed in the female soon after she passes the first molt, and at maturity it is plannly visible, occupying much the larger part of the body cavity.

From the long series of observations made, covering nearly two years, it is concluded that the sexual form plays a very unimportant part in the propagation and perpetuation of the species in this latitude.

The agamic individuals are always present, usually in great numbers on the roots and to a less extent on the stems of the apple trees, and these colonies persist, so far as our observations go, and reproduce other agamic individuals in a direct line without cessation and without apparent loss of virility.

\section{ON THE LIFE HISTORY OF PROTOPARCE CAROLINA.}

By Wm. B. Alwood, Blacksburg, $\nabla a$.

[Abstract of paper.]

In the spring of $1890 \mathrm{I}$ began observations on the life history of the tobacco holn-worm, Protoparce carolina, at Blacksburg, Va. It may be well to state that, although this place is well toward the southern boundary of Virginia, it has a temperate climate, similar to middle New York, because of its elevation, the mean height above tide being about 2,500 feet; but the temperature is also influenced by the prevailing northwest winds, which come to us over the higher ranges of mountains. The soil is mostly heavy clay. Frosts occur in spring, usually until the middle of May, and in the fall about September 20 to 30 our first frost is to be expected.

The tobacco grown is the heavy dark varieties.

The earliest dates at which the moths were observed were June 7 , 1891, June 9, 1892, and June 12, 1s93, and almost invariably in any year by the 12th of June moths in small numbers may be taken at 
honeysuckle in the early evening. I have never seen the moths occur in numbers in June.

By June 12 the tobacco plants have usually been partially set out, but many are set later in some seasons.

The early moths, in my observations, confined themselves to tobacco plants remaining in the plant beds, and the earliest recorded egg laying occurred June 20. After this date eggs were constantly found, but in small numbers, up until after the middle of July, when they became more abundant. They are always deposited singly and nearly always on the under side of the leaf.

From the fact that eggs are deposited in the dusk of evening, it is not easy to be certain that one has the exact date of oriposition in any case, as the eggs are necessarily not found until the next day. However, eggs, presumably fresh, hatched in periods varying from four to eight days.

The first molt occurs under normal conditions almost invariably on the fourth or fifth day from hatching. The subsequent molts occur quite regularly in four to five day periods, there being invariably four molts before pupation. Frequently the larvæ eat the eggshells after hatching and the shed skin after the earlier molts. A sample record will illustrate the statement as to periods of molting:

July 20, 1891, two eggs (not freshly deposited); July 21, both have hatched; July 25, first molt occurred; July 28, one larva disappeared; July 30, remaining larva molted second time; August 4, third inolt; August 8, fourth molt; August 13, larva full grown, burrowed in soil; August 25, pupa removed in good condition.

The records of a large number of larvæ, carried through from egg to pupation, showed four ecdyses, with characteristic changes in the larvie, before attaining full growth and burrowing in the earth for pupation. After entering the soil the larva burrow extensively, in some instances, before coming to rest and forming the oblong cell in which pupation takes place. This cell is simply a cavity in the earth, made by pressing the earth particles firmly and smoothly out of the way, so that before pupation the larva lies free therein. Pupation, in my observation, never occurs under seven days from time of entering the soil, and is usually completed within twelve days.

These records are of worms in confinement, and I should say that the larvæ on entering the soil often showed much restlessness under these conditions.

The number of broods per year is a matter of some interest. Having approximately settled the question of first occurrence of imago and the beginning of oviposition, as full observations as circumstances permitted were made on growth period of the larva and period from pupation to issuance of imago.

The earliest recorded larvæ observed hatched June 21. The earliest larva of which full record was made hatched June 28. Two larve of 
this date completed growth and entered the soil July 19, or in twentyone days. Eight days later pupation was completed and the two pupe examined; apparently normal; removed to cage under cover for observation. One imago issued August 23, or twenty-seven days from pupation. The other pupa was examined at this time and found to be dead.

Our records show these early larva produce moths occasionally up to September 5, but, so far as we are able to determine, the great bulk of the pupæ remain dormant until the following season. Of fed larvæ, the earliest record of issuance of the imago the following spring in my notes is June 24. This larva completed feeding on August 4, previous year, and went into the ground on that day. From this date (June 24) up through July I have constant records of issuance of moths from over-wintered pupæ, the last date being July 29. Larvæ occur, feed, and pupate up to the last of September at Blacksburg, the last ones usually occurring upon tomato.

It would appear from my observations that this moth is, to a slight extent, double-brooded at Blacksburg, but that on the contrary the greater per cent of the overwintered pupæ produce imagos in July, and that the larvæ from these moths quite invariably enter the pupa state in twenty-eight to thirty days from hatching and lie dormant as such over winter.

The breeding experiments were carried on for two years and extended into the third year. Many hundreds of larvæ were under observation during this time, but the procuring of accurate data was often much interfered with by two enemies of this sphinx larva.

These were the common Braconid Apanteles congregatus, the pupa cases of which are seen so frequently attached to the larvæ late in the season, and a Tachinid fly of the genus Chætolyga, the larvæ of which attack the horn-worm pupæ in the soil. Many of our fed specimens were in this wise destroyed, in some instances fully three-fourths of the pupæ being destroyed by the Tachinid.

The discussion took the form of a number of questions propounded to the author by Messrs. Johnson, Howard, Fernald, and others.

MORNING SESSION, SATURDAT, ATGUST 20, 1898, 11.15 O'CLOCK.

The first hour of the morning was spent by the association in the joint meeting with the Society for the Promotion of A gricultural Science, as already provided, listening to the reading of papers on entomological subjects. the reports of which will be given in the proceedings of the society mentioned. 
On the reassembling of the Association of Economic Entomologists the first paper was presented by Mr. F. W. Rane, on the following subject:

\section{NOTES ON THE FERTILIZATION OF MUSKMELONS BY INSECTS.}

By F. Wur. Raxe, Morgantown, $\Pi$. Ta.

Last season a great many varieties of muskmelon were grown at the New Hampshire Colleg( A gricultural Experiment Station. The season, however, was very wet, and much of the fruit did not set, which was attributed to the absence of insects, upon which the plants are supposed to depend.

As we stated in Bulletin 52 of last season, we are now carrying on some experiments in hand fertilization to determine if the operation is successful, whereby we would be independent of unfavorable seasons. We found that we have been mistaken in our idea that the muskmelon is moncecious, as upon examination of our entire list of ninety-five varieties the so-called pistillate flower is to all appearances, excepting in the mammoth varieties, perfect. According to this, the flowers were not necessarily fertilized from the pollen carried from one to another. Upon microscopical examination it was found that to all appearances there was equally as much pollen in the perfect as in the staminate flower. Many flowers containing pistils were covered with bags before they liad opened, and self-pollinated when fully open; while others were simply covered to see if they were capable of self-fertilization. We have succeeded in setting some of the fruit fertilized by its own pollen, although it is not yet mature. Where we did not hand pollinate the fruit has not set.

Upon close observation of the insects at work, and from the structure and arrangement of the stamen and pistil, we believe that self-fertilization through the agency of insects is quite the natural one. The trilobed pistil is so formed that the three stamens are virtually set into grooves, the pistil projecting upon all sides. When the insects come in search of nectar it is but natural that the pollen from this flower be brought into contact with the stigma.

Should self-fertilization prove successful, there seems to be no explanation of the office of the staminate flowers, which are so numerous. When watching the insects at work upon the melon blossom I have seen a single bee go from flower to flower for five minutes without touching a single so-called pistillate blossom. Accordingly, I have had one row picked each day of its staminate flowers to see if a larger proportion of the fruit would set. I find that we have only about the same amount of fruit set thus far on this as in the other rows. With a season like the present, when the insects are numerous, doubtless there is little gained in so doing, but to insure fertilization in seasons when insects are few it seems plausible. 
It was my intention to report upon the insects most commonly visiting the muskmelon flowers, but as Mr. Fiske, the assistant entomologist of the experiment station, is here, he doubtless will give a brief report in the discussion.

In the discussion of this paper the question was asked by Mr. Smith whether the insects remained in the flowers over night. Mr. Rane, in reply, stated that some of the munte ones did. Mr. Smith reported that in case of cucurbits certain insects, especially a species of bee, remained over night in the bloom, and that this fact led him to ask for additional confirmation of this habit.

Mr. Fiske suggested that the male Bombus might have this habit, and Mr. Smith said that this might be true, but that he referred also to a smaller bee, Tenoglossa pruinosa.

Mr. Weed read the following paper:

\section{NOTES ON TENT CATERPILLARS.}

By Clarence M. Weed, Durham, N. $H$.

For the last five or six years the central portion of New England has suffered from the ravages of the American tent caterpillar to an extraordinary degree. Over large areas the musightly nests were to be seen along every roadside and in nearly every orchard. In many localities the outbreak apparently reached its maximum in 1897, during which season large numbers of parasites of many species were at work upon the larva. Egg parasites were also present; these, with certain diseases and various vertebrate enemies, did much in checking the pests last year.

During the present season in the region under the writer's observation there appears to have been a decided checking of the attack due to various natural causes. Just after the larvæ had hatched last April a heavy and long-continued rainfall caused the death of enormous numbers. An examination of the apple and wild-cherry trees after the storm showed that in most cases the only larvæ present were those huddled together on the lower side of the egg mass, where they were protected from the washing effect of the rain. These survivors developed in sufficient numbers to be decidedly in evidence in May, but they had to succumb to a very great extent during the last weeks of their growth to a bacterial disease that killed them in vast numbers. The effectiveness of this disease was doubtless increased by the wet weather prevailing at that time. Early in June nearly every nest was full of dead and dying caterpillars, many of those on the outside of the web gradually shriveling up until only the dried skins remained. A series of observations marle upon a large number of nests just before the time for pupation showed that more than 90 per cent had been killed by this disease. As a result there were few of the caterpillars crawling about 
the streets in early June, although during previous years great numbers were to be seen at that time. There were also comparatively few moths to be found later in the season.

This wholesale destruction of the Clisiocampa larvæ must have brought about also a very general destruction of the parasites of these caterpillars. In $1897 \mathrm{Mr}$. Fiske and myself had begun an interestmg study of these parasites, observing many facts regarding the curious interrelations of host, primary, secondary, and tertiary parasites, which we hoped to complete in a measure this season; but the microbes interfered with all that.

Our 1897 studies showed, however, that Pimpla conquisitor was much the most abundant parasite. Several hundred adults of this species were bred, which appeared to have attacked the occupants of at least half the large number of Clisiocampa cocoons collected. The eggs appear to be deposited in the full-grown caterpillars and to be developed into larva that do not emerge from the host until the latter spins its cocoon. The pupa stage of the parasite lasts from five to seven days. The most abundant secondary parasite preying upon Pimpla conquisitor was Theronia fulvescens, which was reared in considerable numbers. Many other parasites were reared and studied, accounts of which we hope soon to record in a bulletin of the New Hampshire College Experiment Station.

Various experiments with remedies brought out little new information. The careful use of a very small amount of kerosene (a teaspoonful to a nest) in wetting the silk of the nest was found a satisfactory way of killing the partially grown caterpillar; but care is needed, as if sufficient kerosene is added to saturate the bark the tree is injured. One of the most satisfactory remedial measures that came to my notice related to the removal of the egg clusters. In the village of Newfields, $\mathrm{N}$. H., the improvement society offered the school children 10 cents a hundred for all the egg masses, or "caterpillar's belts" as they are locally called, that they would bring in. Many of the children worked faithfully, and when in February I was called to point the moral of the process I found that $\$, 250$ of the egg masses had been obtained. I doubt if the expenditure of $\$ 8.25$ by a village improvement society often does more good than was done in this case. The caterpillars were destroyed, and the effect was easily noticeable in the spring and early summer, while the boys and girls had a remarkable lesson in nature study.

A more serious outbreak than that of the American tent caterpillar, because more sweeping in its character, is that of the forest tent caterpillar (Clisiocampa disstria), which has gradually been developing in New England during the last three or four years. At present the attack is most severe in New Hampshire in the Connecticut Valley, where a great deal of damage has been done over an extended area, but there is evidence to show that the insect is gradually increasing in many regions away from this valley. 
These caterpillars have attacked nearly all kinds of deciduous trees, causing special damage to shade trees like the elm and maple. Many sugar orchards have sustained injury that will interfere with their productiveness in the immediate future. The attack appears to have been more severe in the villages than in the country.

The disstria caterpillars hatch a week or more later than do those of the americana, and there is considerable variation in the time of hatch. ing within the species itself. In a given region caterpillars of various sizes conld easily be found late in May or early in June. They feed on leaves in all parts of the tree, having a preference apparently for the upper branches. They commonly eat out the blade along either side of the midrib, severing the marginal part so that it falls off. These severed portions are to be found abundantly on the ground under the infested trees. The result of this curious mode of attack is, of course, greatly to increase the amount of damage done for the amount of leafage actually consumed. At times of molting the caterpillars collect together in masses on the tree trunk.

Cocoons are spun for the most part after the middle of June. Many of the caterpillars in the trees inclose their cocoons in leaves, while many make them in the bark, and others on the ground, in any shelter that may be at hand.

Mr. Perkins discussed this communication and stated that he had much experience with $C$. disstria, and that it was especially bad on the west slope of the Green Mountains, affecting chiefly the sugar-maple groves. It was less troublesome on the Connecticut River side. Referring to the two species, he noted the confusion likely to arise from the not infrequent occurrence of the two species in the same nest. He confirmed Mr. Weed in the very greatly increased parasitism of the present year, and concurred with him in assigning great value to hand collection of eggs.

Mr. H. T. Fernald described an unusual habit as noticed by him in Pennsylvania. In a large peach orchard the insect was found on perhaps one tree in ten, and yet did not occur at all in an adjoining apple orchard.

Mr. Forbush presented the following report:

\section{RECENT WORK OF THE GIPSY-MOTH COMMITTEE.}

By E. H. Forbush, Malden, Mass.

[Author's abstract.]

Ever since the gipsy-moth exterminative work was placed under the management of the Massachusetts board of agriculture, the plan of operations has been to work from the outermost limit of the known infested region toward the center.

Obviously such a method, if properly executed, would best carry out the purpose of the State law; first, for the prevention of the spread, 
and second, for the extermination of the moth. In accordance with this plan it has been the policy of the board to clear the outer towns from the moth, and at the same time to reduce, so far as the money granted would permit, the number of the moths in the central towns. It was hoped that when the outer towns were cleared the force could be largely concentrated in the inner towns, clearing them also. If the board had each year received the sums it has deemed necessary and annually requested, this policy would by to day, it is believed, have been carried on to complete success. But since the necessary legislative grant annually asked for by the board has been cut down year after year from one-third to one-half, the moths have so increased in the central towns that they have been scattered into and have seriously threat. ened the towns cleared or nearly cleared in the outer belt.

Under these circumstances it has been found necessary during the seasons of 1897-98 to concentrate large bodies of men in the central towns to prevent a further wide dissemination of the larvæ into the outer towns; the outer towns meanwhile receiving less than their full share of attention.

The present year the full amount asked for $(\$ 200,000)$ was granted for this work by the legislature. Unfortunately the grant was so delayed that much of the necessary work of egg destruction (by burning before hatching time) could not be done. The heavy rains, too, which prevailed through May and June greatly hampered the spraying. Nevertheless, the burlap work. which was done more extensively than ever before and over most of the territory known as infested, proved so successful, that nowhere in the whole burlapped territory were any considerable number of trees stripped by gipsy-moth larvæ.

We have also this summer done extensive burning, beginning in August. Burning will be continued where needed.

On the whole, the granting this year of the full sum asked will make it possible for us to accomplish far more in 1898 than has been accomplished in any previous year.

While it is true that two colonies of the insect (one in Lincoln, discovered in 1897, the other in Manchester, discovered this year) are known immediately outside of the limits of the territory hitherto defined as infested, these discoveries, under all the circumstances, do not in the least surprise me, since $I$ have believed from the first that a few of such extralimital colonies might confidently be looked for. Still these discoveries emphasize the necessity of far more inspection work outside the limits of known infestation. We have been absolutely unable in past years, with the money hitherto granted, to do nearly all that is needed to be done in this line of work. This year as much as possible was done in this line, revealing, however, no infestation.

Efficient work has been done both in Manchester and Lincoln. The center of the Manchester colony appears to be stamped out. Much work will be necessary in its immediate vicinity this fall and the country surrounding it must be carefully watched next year. The Lincoln 
colony has been brought to such a condition that there is little danger of dissemination from it.

Nevertheless, the moth is scattered through hundreds of acres of woodland there and extermination in Lincoln and the adjoining town of Weston, into which a few larvæ have been dispersed, will be costly.

The work of spraying and burning the past season has been greatly facilitated by improved apparatus prepared under the direction of Mr. E. C. Ware, of the department, and in part invented by him. An invitation is extended to the association to inspect this apparatus at our Malden office. [This invitation was accepted by a large delegation from the association.]

Information about the gipsy moth has been widely scattered through the region adjacent to the infested territory. People have learned to dread the moth and are on the watch for it. The Lincoln and Manchester colonies were discovered and reported to us by citizens. To secure still further the intelligent cooperation of citizens in this work, it is planned to distribute from house to house, within the towns immediately bordering the infested region, an illustrated bulletin descriptive of the gipsy moth, its habits, and something of its history.

In no previous year have we been able to speak so confidently of progress so early in the season. The great wooded tracts, especially in the eastern, western, and northern divisions of the infested territory, are now in excellent condition. More than ever this year have I been impressed with our power to cope with and in due time to utterly extirpate the gipsy moth when we are sufficiently supported by legislative grants.

If the legislature promptly provides for several years to come an appropriation strictly limited to the gipsy-moth work and equal to the amount granted this year, there can be no doubt of the final extermination of the gipsy moth from Massachusetts.

This paper was preliminary to an excursion to the gipsy-moth districts, offered by the gipsy-moth committee to the members of the association, to occupy the afteruoon of the last day of the session, and the discussion of the communication was deferred to an informal one during the excursion.

A committee, consisting of Messrs. Bethune, Osborn, and Smith (J.B.), was appointed to express the opinion of the members of the association regarding the work against the gipsy moth in the State of Massachusetts. The report submitted by this committee follows:

Resolved, That the work of the gipsy-moth committee in the State of Massachusetts, having been inspected in all its details by a large number of the members of this association and its methods of operation observed, it is our opinion that too much praise can not be bestowed upon those who are carrying out this important work. We consider that they have adopted the best methods yet devised for con- 
trolling the spread of and ultimately exterminating this destructive insect; that their work, on the whole, has been remarkably successful, when the extensive area to be gone over and the insufficient or retarded appropriations are considered; and that there is every prospect of the accomplishment of the object of the committeethe absolute extermination of the insect in the State of Massachusetts-prorided that funds sufficient for the purpose are placed at their disposal.

We consider that a stoppage of their work, or any serious reduction of it, would involve not only the loss of all that has been already accomplished, but would also permit this destructive insect to ravage the State and eventually spread over a large part of the Union, and cause an incalculable amount of injury to the whole community.

We trust that the Commonwealth of Massachusetts will continue to make early and ample provision for carrying on this work in a thorough manner for a few years longer, when we expect that the insect will have been brought under such control that a much more limited expenditure will be sufficient.

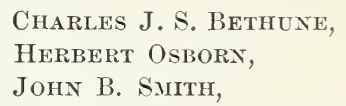

Charles J. S. Bethune, Herbert Osbors, JohN B. SiIth,

Committee.

The papers not read, or the authors of which were not present, were ordered read by title and printed in the proceedings.

On motion of Mr. C. H. Fernald, seconded by Mr. Weed, the United States Department of Agriculture was asked to undertake the publication of the proceedings, as has been the custom hitherto.

The following new members were proposed and added to the rolls:

F. H. Mosher, proposed by Mr. Kirkland.

E. D. Ball, assistant entomologist Colorado Experiment Station, proposed by Mr. Osborn.

A. L. Quaintance, State entomologist, Florida Experiment Station, proposed by $\mathrm{P}$. H. Rolfs.

A vote of thanks was tendered to the officers of the association for the efficient performance of their duties, and also to the Boston Society of Natural History and the Horticultural Society of Boston for use of halls and other courtesies.

The association then adjourned, to meet in accordance with the usual custom, on the two week days preceding the annual August meeting for 1899 of the American Association for the Advancement of Science, and at the place selected by the latter body.

$$
\text { C. L. MARLATt, Secretary. }
$$

The following are the papers read by title and ordered printed in the proceedings:

\title{
THE SAN JOSE SCALE IN CONNECTICUT
}

\author{
By W. E. Brittox, New Haven, Conn.
}

The presence of the San Jose scale (Aspidiotus perniciosus Comst.) in the State of Connecticut was first discovered in 1895. On June 12, while investigating a leaf-curl of plum trees in the orchard of $\mathrm{Mr}$. J. L. Raub, at New London, Dr. W. C. Sturgis, mycologist of the experi$7184-$ No. $17-6$ 
ment station, observed that several small peach trees had just died, and upon further inspection found the trunk and branches of each dead tree well covered by scale insects. "Twigs were taken to the laboratory in New Haven, where they were given a more thorough examination. The scale was suspected to be the San Jose, or pernicious scale, but as no one at the station had ever seen that species, specimens were submitted to Mr. M. V. Slingerland, of Cornell University, and to Dr. L. O. Howard, of the Department of Agriculture, at Washington. Both pronounced it A. perniciosus. The writer visited MIr. Raub's orchard on June 25, in company with Dr. Sturgis, and took notes regarding the infested trees and their surroundings. The orchard was badly infested. Fortunately, however, it was the only orchard in the immediate locality, so that the conditions necessary for the rapid spread of the insect were not at hand. Living scales were found upon about half the trees, but there were also many dead scales which were about half grown and had probably been killed the previous winter. Trees of the orchard were obtained from the Pomona nurseries, Parry, N. J., during the seasons of 1891, 1892, 1893, and 1894. The plantings of 1891 and 1892 were badly infested, and it was amongst these that the dead trees were found. The stock of 1893 undoubtedly was infested when planted, but was still vigorous, while the trees planted in the spring of 1894 appeared to be free from scale. Previous to this the owners of the above-mentioned nurseries had instituted vigorous measures to rid the stock of insect pests. Mr. Raub destroyed immediately many of the worst infested trees of his orchard, and applied whale-oil soap solution to the other trees. This treatment was repeated the following April, and gave good results. Early in the spring of 1896 a bucket of "Dendrolene" was sent to the station by its manufacturers, the Bowker Fertilizer Company, of Boston, and Dr. Sturgis forwarded it to Mr. Raub, with the request that he give it a trial on some of his trees. Through a mistake all trees of the orchard which were infested with scale were coated with the substance about May 1. On June 4 Mr. Raub wrote that all of his trees were dying. A later examination proved that the trees had been killed by the "Dendrolene," and by killing the trees the scales were destroyed.

As soon as it was learned that infested nursery stock had been sent into Connecticut from Parry's nurseries, a letter was addressed to Mr. Parry asking for a list of his Connecticut customers during the period between 1890 and 1895, that we might the more readily learn of the extent of the distribution of the scale in the State. Mr. Parry courteously complied with our request, and sent us a list containing ninetytwo names.

Circular letters were sent to these addresses calling attention to the presence of the scale in Connecticut, and asking each owner to examine his stock and report, a card for reply accompanying each circular. Forty-three replies were received. Twenty-eight reported no scale, while ten found indications of its presence. 
Shortly after the pernicious scale was discovered at New London, specimens were received from Hartford and Bridgeport. Still later it was learned that infested localities existed at Darien, Groton, Mystic, Farmington, New Britain, Plantsville, and New Haven. At this date (August 18) we may add to the list Greenwich, Nichols, Woodbridge, Hamden, Cheshire, Wallingford, Meriden, Ivoryton, and Burnside.

Thus, infested localities are known to have existed in at least nineteen different towns of the State, while three or four different localities in Hartford and at least five in New Haven have been discovered. It may also be of interest to note that most of the centers of infection are

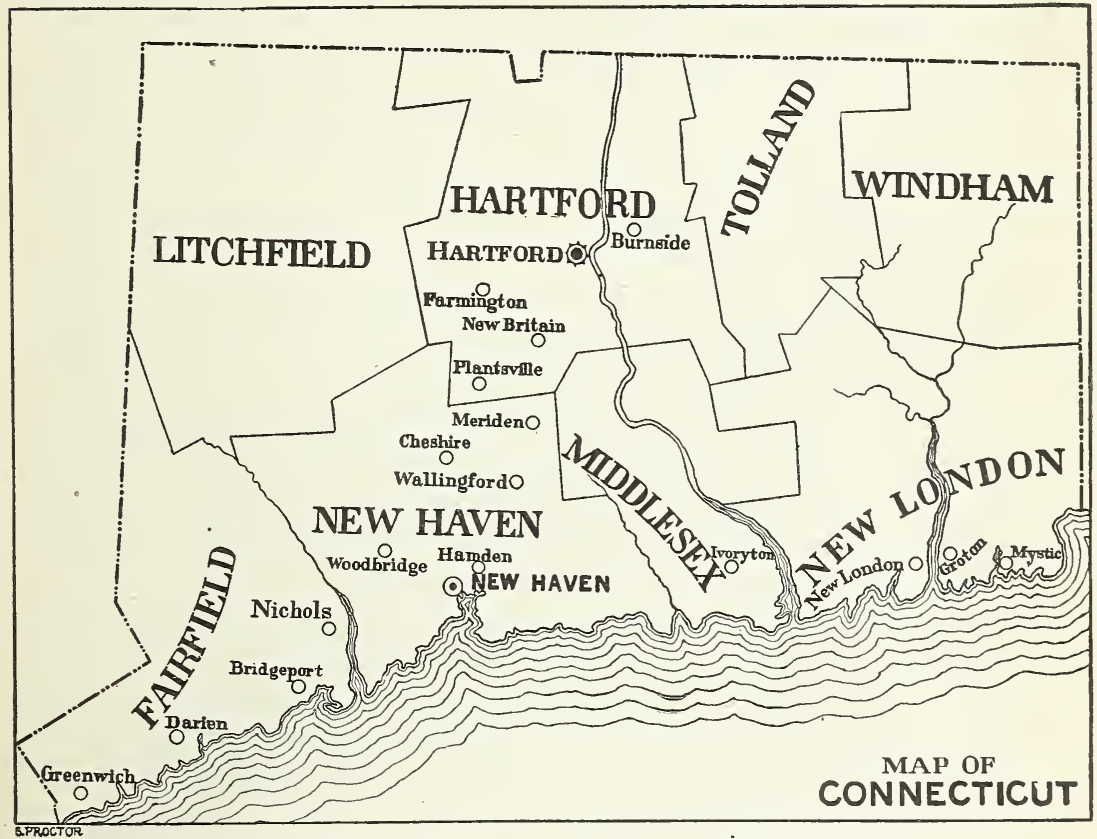

Fig. 4.-Map showing the distribution of the San Jose scale in Connecticut (original).

situated along the lines of the New York, New Haven and Hartford Railroad. ${ }^{1}$ In nearly all cases where infested trees were found the - owners had purchased stock of either Parry or Lovett. In one or two cases infested stock was unquestionably obtained directly from other nurseries, but it may have originally been sent out by one of these two New Jersey firms. No list of customers has been procured of the Lovett Company, and it is probable that many other localities, to us unkuown, have already become infested by means of stock from this nursery.

During the latter part of 1897 infested currant twigs were received from Mr. M. N. Wooding, of Hamden. A visit to Mr. Wooding's place followed, and an inspection of all vegetation in the vicinity showed the

${ }^{1}$ All localities now known to exist in the State are shown on the accompanying outline map (fig. 4), prepared by the author of the paper.-L. O. H. 
only infested spot to be in the center of a small currant patch, having an area of perhaps one-fourth of an acre. Mr. Wooding had grown his own plants from cuttings for twelve years, and had purchased no currant stock from nurseries. Only three or four bushes were infested, and how the scale got there remains a mystery.

In suggesting a treatment against the scale we have usually advised the destruction of the worst infested trees, and recommended that others be sprayed while dormant with a solution of whale oil soap-2 pounds of soap in 1 gallon of water. If considered best to spray trees in foliage, 1 pound of soap to 5 gallons of water has been advised. On the 1st of last Narch several seriously infested Japan plum trees in New Haven were sprayed with kerosene. Two months later no living scales could be found. The kerosene was applied by means of a "Success" bucket puinp, throngh a Vermorel nozzle, and the spraying done on a bright day, with plenty of air stirring. Where the kerosene was applied with care, little or no injury resulted. One tree literally covered with scales was drenched with kerosene; nearly all the branches were killed back about halfway to the trunk.

At the station uninfested trees of apple, pear, peach, plum, cherry, and quince were sprayed with kerosene February 28. The only injury that resulted was the killing of a few fruit buds.

During the past year the writer has been called upon to inspect four different nurseries. In two of them no "indications of the presence" of A. perniciosus were found, and the owners were provided with certificates to that effect. Each of the other two nurseries contained a few small trees that were scale infested.

Connecticut h $\sim$ s no law requiring the inspection of nursery stock, but these inspections were made at the request of the owners. Several cases have been noted where infested trees were purported to have been purchased from local dealers whose stock had been examined and was apparently free from scale at the time of the inspection. The location of these trees being such as to preclude the probability of their having become infested after leaving the nursery leads me to believe that the San Jose scale has been distributed very extensively in Connecticut upon nursery stock, and that nearly erery nursery in the State has at some time contained infested stock which the owners have unwittingly sold to their customers.

\section{INSECT INJURY TO MILLET.}

By F. H. Chittendex, Washington, D. C.

FLEA-BEETLE INJURY.

During the last week in June, 1898, Mr. C. L. Shears, of the Division of Agrostology of the U.S. Department of Agriculture, called the writer's attention to injury on the experimental plats of millet on the Department 
grounds. On investigation it was found that two species were at work, Chatocnema denticulata Ill. and pulicaria $\mathrm{Cr}$. The former was by far the most abundant species of insect on the entire experimental plat, and was so numerous on broom-corn or Indian millet (Panicum miliaceum) as to be readily seen at a few paces distant. A smaller number of the latter species was present on the same plat, and both were found in considerably smaller numbers on other species of millet, the injury effected being hardly appreciable. The following were infested in the order named: Panicum capillare and molle, German millet (Setaria germanica), and pearl millet (Pennisetum spicatum). Adults were in copula for the most part, and many were hidden in the panicles of the flowers, where the grass blade partially concealed them from view. Nearly every leaf of broom-corn millet was badly injured, damage showing in holes varying from the size of a pin prick to long slits a quarter of an inch and more in length. The blades were also badly discolored, this discoloration showing as long white marks placed closely together.

From adults captured during the first week of July eggs were obtained. The following week the beetles were noticed in decreasing numbers, and search made about the roots at different times till August failed to discover the insect in any stage of growth, although nearly a hundred plants were examined. Careful examination of many plants about the roots showed injury by some larva, particularly just above the roots and at the bases of some of the larger ones. It was very plainly the work of a coleopterous larva, as shown by the nature of the attack and the excrement, but it could not be discovered whether it was the work of Chrtocnema or of the wireworm larva, which was found in some numbers at the same time and which will be mentioned later.

The following description of the egg of Chcetocnema denticulata is given: Subelliptical, a little larger at one end than at the other. Opaque, pale buff yellow. Surface of moderately small shallow concave areas, perfectly hexagonal, with thin edges, like honeycomb, when seen under a high magnifying power; a few scattered granules. Length, 0.74 to $0.76 \mathrm{~mm}$.; width, 0.26 to $0.29 \mathrm{~mm}$.

This flea-beetle, it will be remembered, was mentioned in a paper by the writer presented before the last meeting of the Association of Economic Entomologists (Buil. 9, n. s., Div. Ent., U. S. Dept. Agric., p. 22) as an enemy of the common barnyard grass, Panicum crus-galli, the prediction that it would "probably be found later to be injurious to some of the useful Graminaces" being now verified. We must look for its native larval food plant among our indigenous species of Panicum.

\section{WIREWORM INJURY.}

July 12, while searching for the larvæ of Chætocnema on the plat of broom-corn millet previously mentioned, larva and pupæ of the wireworm, Monocrepidius bellus Say, were found at the roots of many plants. 
The species was mostly in the larral condition and the pupr found had recently transformed. The roots of this plant are rather short, and the larve were for the most part within an inch or two of the surface of the ground. Ten days later practically the same conditions were observed, the species still being chiefly in the larval condition. One beetle fully matured, however, was taken and one of the pupe found on a previous occasion had begun to mature.

The pupie did not attain maturity, but on July 22 a full-grown larva was taken, which transformed to pupa that day and to adult on the 28th, having passed about six days in the pupal condition. The weather was very hot during this period. On the day of its transformation the beetle was of a light yellow color. This changed to reddish on the following day, and the normal coloration of the species could be seen on the afternoon of the 30th. When next examined, August 1, it was fully matured and actively running about in the rearing jar in which it had undergone transformation.

Monocrepidius bellus has not, to the writer's knowledge, hitherto been noticed as injurious. Its larva and pupa are almost exact counterparts in miniature of $M$. vespertinus, a common species southward in corn fields. The larva when mature measures 6 to $6.5 \mathrm{~mm}$. in length; the pupa is of about the same dimensions as the beetle, $3.5 \mathrm{~mm}$. long.

\section{-OTHER INJURIOUS INSECTS; SUMMARY OF INJURY.}

The Southern corn root-worm (Diabrotica 12-punctata) was also found in the larval stage, and beetles were taken that had just transformed from pupa; this observation adding a new larval food plant for this rootworm. Young larvæ of a species of Lachnosterna were also at the roots, as was the larva of an Oscinid fly, Chlorops assimilis. These species, with the addition of the chinch bug, which was present in all stages, make a list of seven species of insects attacking this plant. It was the worst injured of all the forage plants on the Department grounds, and from this experience it would appear that this species of millet could not be profitably grown in the States lying in the same life zone-the Upper Austral-as the District of Columbia.

The flea-beetles had done the most injury of all the insects enumerated, the most obvious damage having been committed in their mature condition. Unfortunately, owing to the bad condition of this particular plat, the workman in charge cut down what remained of it after the writer's first observations, and it was impossible to carry the matter further. The wireworm larve occurred in considerable numbers and materially assisted in injury, and all the other insects, with the possible exception of the Chlorops, are capable of much damage. 


\section{ENTOMOLOGICAL ETHICS.}

By T. D. A. Cockereli, Las Cruces, 1. Mex.

"What then? Shall we sin, because we are not under lau, but under grace? God forbid̄."-Paul, Epistle to the Romans, v1, 15.

I am aware that a Biblical text is not the customary prelude to a paper presented to this association, but the words of Paul are so appropriate to what follows that no excuse is needed for quoting them. Entomologists in the public service enjoy a large amount of liberty. I think we are all glad that such is the case, and would be, without exception, resentful of any attempt to diminish our freedom. Science must be free-must be allowed to follow the devious path that leads to the summit of the hill of knowledge, even though that path often seem to have no trend in the direction of the distant goal. In the name of science we demand the right to investigate as we will, and publish without hindrance whatever results we obtain.

It is, however, quite certain that liberty in matters scientific, as in the state, can only be maintained when rightly used. He, therefore, who misuses his freedom is an enemy of the whole fraternity, for he threatens its most precious possession.

I think we need to consider among ourselves what is our precise duty to the United States and to one another. In certain particulars I have observed very diverse practices and very divergent opinions, and it can not well be that these are all correct.

The entomologists of the experiment stations are all of them custodians of more or less extensive and valuable collections of insects. What may they do with these collections? What are their rights in regard to them?

I have myself observed the following rules:

(1) The entomologist has no private ownership of anything in the collections.

(2) The specimens may be disposed of in any manner which best furthers the interests of science. This involves the two following rules:

(a) Specimens, even uniques, may be sent to specialists who will work them up and publish the results. It is, I think, far better to part altogether with a rare specimen than to have it remain in the collection unstudied. As others take the same view, it results that the collection acquires from elsewhere corresponding numbers of raluable specimens belonging to the groups specially studied by the entomologist.

(b) Types of new species ultimately go to some central institution, preferably the U. S. National Museum. This is important, because in the long run much trouble is saved to entomologists by having the types all together; and also, because such places as the National Museum offer a far better guaranty of safe-keeping than most, at least, of the agricultural colleges. 
I may add to the first rule that I do not keep any private collection whatever. I do not know whether you will agree with the above rules, but after much consideration I believe them to be sound.

Now, it is on the question of private ownership that difficulties have arisen, and I believe that some entomologists have permitted themselves entirely too great liberties.

One of our station entomologists actually has advertisements running in the entomological and botanical journals, offering insects and plants for sale. I think we ought to agree that no station official should sell any part of his collections, unless, of course, the money is turned in to the institution he is serving. Even so, it would not usually be wise. It is quite impossible for a man to conduct a private business and at the same time be a faithful station official, even admittingwhich I do not admit-his right to so dispose of a portion of his material.

1 believe a station official never ceases to be on duty, but that even when on leave of absence he should lose no opportunity of serving, I will not say the institution, but the science for which the institution exists.

While I have said this, I wish it to be understood I am concerned with the motive rather than the deed. As a college professor, I have considered my duties to extend far beyond the four walls of the college building, and have, in fact, gone so far as to produce and edit an educational journal. This may appear to you a sin against the law that no public official may conduct a private business; but there was just this about it-it was not a private business, but a public one. The sole aim of the publication was to further the interests of education, and I think an inspection of its balance sheet would convince the most skeptical that there were no financial ends in view.

This last instance shows the value of our freedom, for it would be hard indeed to frame laws which would prevent all improper enterprises and yet not interfere with any proper ones.

To return to the matter of collections. A very serious question is, What may a man take away with him when he leaves an institution? It is a great hardship to be severed from a collection on which one has labored for many years, perhaps through no fault of one's own, and with the knowledge that the next man will be quite unable to make proper use of it. Yet I would say that the entomologist ought only to take a set of duplicates, and that with the knowledge and consent of the authorities. In one case known to me the entire collection of one order of insects was removed, not a single named specimen being left. This was done in perfect good faith, and no objection was made at the time. I mention it merely to show how extreme are the differences of opinion on this subject and how desirable it is to arrive at some mutual understanding.

It has lately been charged that specimens have been removed from 
one of the station collections wrongly and without permission. This can not possibly be tolerated, and I urge that this association take steps to inquire into the matter. If the charge is untrue, it is even more important to investigate it than in the reverse case, so as to remove an unjust suspicion from one of our number, reflecting to the discredit of all of us.

We may now turn to the discussion of certain phases of our relations to one another. What should be the relation between the beginner and the old hand? What that between the collector and the systematist? I think those who have advanced somerwhat in the science do not, as a rule, do enough to help on those behind them. They are, perhaps, sometimes afraid of being themselves outstripped! The number of students of any branch of entomology in this country is lamentably few in view of the enormous field to be cultivated, and therefore no one can do a greater service than to encourage new students.

What sort of encouragement should be given? To name specimens by the dozen is not, I begin to be convinced, the best way. Latterly I have begun to write in this wise: "You say you are going to study Coccidx. Well, study Coccidx, and when you have done so, send me your manuscripts and drawings, and some of the specimens, and we will discuss the subject together." Sometimes one hears no more of the correspondent, but often he gets to work and something really valuable results to himself and the science. The great artificial difficulty of the beginner-that of not having or not knowing where to find the literature, and the natural and inevitable errors of inexperience-can be mostly overcome for him by one more matured in the study; but the observation and recording of the facts of nature should surely be left to the beginner himself.

I think teachers do a very grievous wrong when they allow their students to incorporate their work with their own, and make it appear as if they-the students-had done everything. It is promoting a particularly base kind of dishonesty, and the evil is the more insidious, because the student rarely realizes what he is doing. It has been my experience that beginners will rarely think to give credit for any help they receive, and I have known men to iunocently, and without thought of evil, appropriate even a whole description of a new form, communicated to them in manuscript, publishing it as their own!

Now, as to collectors and specialists. The collector, at the present day, is not properly encouraged, and rarely (there are a few brilliant exceptions) is he helped to make the most of himself. Only to-day I received a journal containing a great number of descriptions of new Coleoptera, and in no single instance was the collector's name mentioned! This is by no means a rare occurrence. Field data, as I have often found, are not asked for, and when received are often ignored or wrongly quoted! This is all utterly bad, and should be remedied at once. I think this association might do worse than appoint a committee of two 
to examine all entomological papers published in America between this and the next meeting, and furnish a black-list of those who had ignored the collectors or the field data.

How much the collector can do, if he knows his work will be appreciated and he will get proper credit! A good way, I have found, is to divide a paper into two parts: (1) Systematic, by the specialist, and (2) biological, by the collector. When the systematist has written his part, he returns it to the collector, who immediately exerts himself to make his part as complete and instructive as may be. The outcome is an article which is both valuable and interesting, and the collector's part of it is frequently the best.

In the above remarks I have, of course, oniy covered a very small portion of the ground, but I hope there will be found sufficient material for discussion and perhaps action.

\section{VERNACULAR NAMES OF INSECTS.}

By Edwin W. Doran, Clinton, Mo.

At the minth annual meeting of the Association of Economic Entomologists, held in Detroit last year, Prof. C. P. Gillette read a paper on this subject, giving a list of the vernacular names of many of our common insects. A committee was appointed by the association to report on the matter at the next meeting. I wish to offer a few suggestions through this committee to the association.

It is very evident to me that in the paper referred to there are several mistakes in the compounding of words. In fact, I believe most of the forms preferred by Professor Gillette are not in accordance with the best usage. There are certain laws for the compounding of words, which are just as definite and fixed as any other laws relating to the use of good English, and I see no reason why entomologists should not observe these laws. It will be a serious blunder to perpetuate upon the present and future generations of entomologists a mass of incorrect forms.

It may be argued that the forms given are in use by many people, and that is true; but many entomologists are woefully ignorant of good English, and should not be allowed to determine matters outside of their sphere. This is a question for English scholars to settle for the most part. I have consulted the best authorities in the English language, and in the list, as I give it, only upon one name is there any disagreement.

In the list of names as published the arrangement is entirely illogical. It is not in accordance with the development of the language in regard to such words. For example, Professor Gillette writes the name in three parallel columns, as illustrated by his first word, thus:

$$
\text { Aphis-lion, Aphis Lion, Aphislion. }
$$


The first form and the second should be exchanged. Then the order of the words will represent a growth; for the more common words become, the more closely they are united-first separate words, then joined with hyphen, then joined directly without hyphen. All words do not pass through the three stages, but they almost invariably pass through the second stage before they are used in the third. Thus we would first write fish-moth; then after long use, we write fishmoth.

The arrangement of the words has much to do with the meaning. For example, a crow is a black bird, but not a black-bird or blackbird. We might even have a white black-bird, but not a white black bird. A cabbage root-maggot would indicate one of many kinds of root maggots; but a cabbage-root maggot would indicate a maggot which feeds upon the root of cabbage, and there might not be another root-maggot in existence. A Colorado potato-beetle would mean a certain kind of potato-beetle; but a Colorado-potato beetle would mean a beetle that injures the Colorado potato. A shifting of the little hyphen entirely changes the meaning.

There seems no use whatever for capital letters, except at the beginning of words derived from proper names, as in Colorado potato-beetle or Angoumois grain-moth. In all other cases I have not used them, though Professor Gillette begins each name with a capital. I have also arranged the names in alphabetical order. They were partly so before.

In the list below, the form which Professor Gillette prefers I have followed with a G. In some cases he gives his sanction to two forms as equally good. The forms I prefer I have followed with a D. We agree on abont one-fourth of the forms.

LIST OF VERNACULAR NAMES.

Angoumois grain moth, $\mathrm{G}$ ant lion, $\mathrm{G}$

aphis lion, $\mathrm{G}$

apple maggot, $\mathrm{G}$

apple weevil, $\mathrm{G}$

bag worm

bark louse, $\mathrm{G}$

bed bug

bee flies, G

bee louse, $G$

black fly, $\mathrm{G}$

black swallow tail

blister beetle, G

boll worm, G

bot $\mathrm{fly}_{\mathrm{y}}$

bristle tail

bud moth, G

cabbage butterfly, G

cabbage root-maggot, D (?) cabbage worm, G caddis $\mathrm{fly}, \mathrm{G}$
Angoumois grain-moth, D ant-lion, D

aphis-lion, D

apple-maggot, D

apple-weevil, D

bag-worm, D

bark-louse, D

bed-bug

bee-flies, D

bee-louse, D

black-fly, D

black swallow-tail, G

blister-beetle, D

boll-worm, D

bot-fly, D

bristle-tail, G

bud-moth, D

cabbage-butterfly, D

cabbage-root maggot, $\mathrm{G}$

cabbage-worm, D

caddis-fly, $\mathrm{D}$
Angoumois grainmoth

antlion

aphislion

applemaggot

appleweevil

bagworm, G

barklouse

bedbug, G, D

beeflies

beelouse

blackfly

black swallowtail, D

blisterbeetle

bollworm, G

botfly, G

bristletail, D

budmoth

cabbagebutterfly

cabbage rootmaggot

cabbagew orm

caddisfly 
carpenter bee, $\mathrm{G}$

cave cricket, $G$

chinch bug, $\mathrm{G}$

clover-hay worm, D

codling moth, $\mathrm{G}$

Colorado potato beetle, $\mathrm{G}$

corn plant louse, $\mathrm{G}$

currant borer, $\mathrm{G}$

cut worm

dragon fly, Gr

fish moth, $G$

flea beetle

flesh fly, G

gall fly

grain moth, $G$

guest fly, $\mathrm{G}$

hawk moth

ichneumon fly, G

lady beetle

lady bug

leaf folder

leaf hopper

leaf roller

pine leaf scale

plant louse, Gr

red legged locust

saw fly

scurvy bark louse, G

silk worm

span worm

squash vine borer

tussock moth, G

two lined prominent

white ant, G, D (?) carpenter-bee, D

cave-cricket, D

chinch-bug, D

clover hay-worm, G

codling-moth, D

Colorado potato-beetle, D

corn plant-louse, D

currant-borer, D

cut-worm

dragon-fly, D

fish-moth

flea-beetle, D

flesh-fly, D

gall-fly, D

grain-moth, D

guest-fly, D

hawk-moth, D

ichneumon-fly, D

lady-beetle

lady-bug

leaf-folder, G, D

leaf-hopper, G, D

leaf-roller, D

pine-leaf scale, $G, D$

plant-lonse, D

red-legged locust, G, D

saw-fly, D

scurvy bark-louse, D

silk-worm

span-worm, D

squash-vine borer, G, D

tussock-moth, D

two-lined prominent, G, D

white-ant, D carpenterbee

cavecricket

chinchbug

clover hayworm

codlingmoth

Colorado potatobeetle

corn plantlouse

currentborer

cutworm, G, D

dragonfly, G

fishmoth, D, G

fleabeetle, $G$

fleshfly, G

gallfly, G

grainmoth

guestfly

hawkmoth, G

ichneumonfly

ladybeetle, G, D

ladybug, G, D

leaffolder

leafhopper, $\mathrm{G}$

leafroller, $\mathrm{G}$

pineleaf scale

plantlouse

redlegged locust

sawfly, G

scurvy barklouse

silkworm, G, D

spanworm, G, D

squashvine borer

tussockmoth

twolined prominent

whiteant

\section{NOTES FROM MARYLAND ON THE PRINCIPAL INJURIOUS INSECTS OF THE YEAR.}

By Willis G. Johnson, College Park, Md.

THE WHITE ANT.-The season of 1898 has been a very exceptional one from the entomological point of view up to the present time. The socalled white ant (Termes flavipes) was the first insect of any particular economic importance to come to my attention. I noticed an account iu a local paper, April 7 , that a swarm of insects had appeared in the Sunday school room of the Protestant Episcopal Church of All Saints in Baltimore during the session of the school which so completely demoralized the scholars that it was impossible to restore order. I made an examination of the place April 8, and found a very serious condition of affairs. The church is a large one, built of stone and brick, with the Sunday school room on the first floor and the auditorium 
above. All the timbers in the floor of the Sunday school room were completely tunneled out by the termites, and the floor in many places had given.away. The insects were still issuing through holes in the floor near the furnace and from under the carpet in a small room adjoining. After this hasty examination, I was convinceri that the entire floor, the sills of which rested directly upon the ground, would have to be removed. The floor was taken out a few days later and my suspicions were well founded, as all the sills had been entirely honeycombed. The insects had also gone up the studding which had been used for lath and plaster against the stone walls for about 6 feet. Even the laths had been mined until they were mere shells. The insects had also tunneled into the hard wood of the rostrum and into the partition dividing the Sunday school room from the class room. It was necessary to remove all the woodwork in the room and replace it with new. About 2 feet of earth was removed and the new floor placed on joists resting on iron girders set upon brick piers. All the heavy timbers were also dipped in tar.

THE BLACK PEACH APHIS.-The black peach aphis (Aphis prunicola) was the next insect to command my attention. April 12 I was called to examine a block of 400,000 peach seedlings in which this insect had made its appearance. Its distribution has been very general over the State, the greatest injury having been done to young peach trees in nurseries just as the buds were shooting. The loss to nurserymen alone, to say nothing about the losses sustained in one and two year old orchards, has been considerably in excess of $\$ 50,000$ this season. No such an outbreak has been recorded in this State for the past eight or ten years.

The Clover-Leaf WeEvil.-The clover-leaf weevil (Phytonomus punctatus) made its appearance and was first observed by us April 12, doing considerable injury in fields near Annapolis Junction. Two days later we noticed the appearance of Empusa (Entomophthora) spherosperma, a fungous disease attacking the larva. By the 1st of May it was very difficult to find a living larva. Their dead bodies were everywhere seen curled about leaves, weeds, straws, in fact, rubbish of all kinds in the field.

The CORN CRAMBUS.-The corn crambus (Crambus caliginosellus) appeared in corn at many places in the State the latter part of May and early in June, causing considerable apprehension about the safety of the crop by the growers. One field, near Hyattsville, was visited by us May 31, at which time several pupa were found. The most of the larvæ were fully grown. July 6, we examined other fields near Mason Springs, Charles County, at which time we found nearly matured larva.

THE CORN STALK-BORER.-The corn stalk-borer (Diatraa saccharalis) has been very common and troublesome in the sonthern and eastern shore counties this season. It is known t most of our planters as the 
"corn bud worm." Early in July I saw many fields in lower Charles County that had been practically abandoned on account of the attacks of this pest.

The Hessian Fly.-The Hessian fly (Cecidomyia destructor) has been largely responsible for the shortage of the wheat crop in this State this season. Fully one-fourth of the shortage reported is due to this insect. In other words, the losses in Maryland this year from this insect are about $\$ 750,000$. Many wheat fields in the northern counties were plowed up early this spring and planted to corn.

The ROSE BUG.-The notorious rose bug (Macrodactylus subspinosus) made its usual appearance this year and did much damage to grapes and peaches. June 8 it was reported to me that this insect had been responsible for the death of a number of young ducks and turkeys. It was stated that the fowls died shortly after eating the insects.

THE BOLL WORM.-The boll worm (Heliothis armiger) has been very abundant in corn, and unusually common in tomato fields, attacking the green as well as the ripe fruit. The injury is especially noticeable in the late crop of tomatoes.

ThE GRAIN MOTH.-Another insect that has been much more common than formerly is the grain moth, Sitotroga cerealella. Its attacks upon corn and wheat in store has been very conspicuous throughout all excepting the three western counties of the State.

I'He CabBage Plusia. - The cabbage plusia (Plusia brassica) has been responsible for the entire destruction of many fields of cabbage this year. The Harlequin cabbage bug (Murgantia histrionica) has been conspicuously absent in most of the central and northern counties, although it appeared in large numbers early this spring. At the present time I am unable to account for the marked decrease of this pest.

\section{ON THE LIFE HISTORY OF THRIPS TRITICI.}

By A. L. Qualntance, Lake City, Fla.

[Published in Bulletin No.46, Florida Agricultural Experiment Station.]

\section{NOTES ON INSECTICIDES.}

By C. L. Marlatt, Washington, D. C.

The writer has presented at various times before this association the outcome of experiments with different insecticide substances. Without referring to miscellaneous subjects, it is proposed to give now merely a résumé of the results so far obtained with pure kerosene, fish-oil soaps, and arsenite of copper (Scheele's green), bringing the records down to date. 
The first essays with pure kerosene against scale insects were conducted in the winter of 1893-94, when a number of peach trees on the grounds of the U.S. Department of A griculture infested with the new peach scale, Diaspis lanatus, were treated with the undiluted oil as one of a series of experiments with various substances against this insect. Applications were made during January and February and later, early in March. The results were very successful so far as the test with pure kerosene was concerned, the scales having been killed and the trees remaining uninjured, blooming abundantly the following spring, and showing no damage later. As this scale is confined to the trunk and larger limbs of the trees, the application of oil was not general, but was limited to the parts named, and deductions could not, therefore, be drawn as to the effect of the treatment of trees in toto. A résumé of the results was presented in August, 1894, at the sixth annual meeting of this association. ${ }^{1}$

In the active experimental work undertaken against the San Jose scale during the following winter (1894-95) the results with pure kerosene against the peach Diaspis were considered of sufficient significance to lead to the repetition of the tests on San Jose scale infested peach trees at Riverside, 1 Id., and in January, 1895, applications of pure coal oil were made to two trees, one badly incrusted with scale, and the other very slightly infested. The scales in this instance were all killed, as had been the case with the Diaspis, but the trees unfortunately failed to survive the treatment. ${ }^{2}$

The outcome of this preliminary experiment with kerosene against the San Jose scale, while demonstrating that the pure oil will kill the scales perhaps more effectively than any other application known, and at very slight cost, was yet accompanied with such disastrous results to the plants themselves that further tests were not made until the subject was again given prominence by the report, in discussion of the use of pure oil, in Ohio, by Mr. Webster, at the eighth annual meeting of this association, in $1896 .{ }^{3}$

Following up this new suggestion of the possible value of undiluted kerosene as a means of controlling the San Jose scale, a series of tests were made during the winter of $1896-97$, and reported last year at the ninth annual meeting of this association.

The outcome of these experiments seems to contradict the earlier tests, although the latter were carefully conducted, and much more so undonbtedly than would be the case in normal orchard work.

As noted in the paper cited, the experiments of the winter of 1896-97 were not followed by any real or permanent injury to any of the trees

\footnotetext{
${ }^{1}$ Insect Life, Vol. VII, pp. 118 and 119.

2 Insect Life, Vol. VII, pp. 365-374.

${ }^{3}$ Bull. No. 6, n. s., Div. Eut., Dept. Agric., p. 42.
} 
treated, and the tests extended to young peach trees and old trees, and also young apple, pear, cherry, and quince trees, and several ornamental shrubs.

In the meantime the experiments of others had given a variety of results, in some cases the plants being killed or much injured, in others no deleterious results following the treatment.

Our conclusions, as expressed at the time, were that spraying with pure oil will often kill trees, and that kerosene as an insecticide is to be used with caution and with the full appreciation of the fact that the death of the plant may result.

In the winter of 1897-98 the tests made with young trees of the previous winter were repeated, the applications being made under different weather conditions; in some instances during cloudy or moist weather, and in others on bright, warm, and dry days. The results duplicated in the main those of the previous year, with the exception of certain peach trees, included in one of the first tests, which were killed to the ground. Peach trees subjected to treatment later were uninjured. The trees killed were sprayed on a still day, with a very moist atmosphere, the sun occasionally breaking through the light fog, and it was noticed that the kerosene remained in evidence on the trees for some time; it seemed in fact to have soaked into the bark during the moist period, and in the bright weather following was not readily given up. Apple, pear, cherry, and quince trees, however, treated at the same time developed no appreciable injury.

The tests, therefore, up to the present time made with this oil indicate that it may often be used with little if any canger to the plant and with perfectly satisfactory results so far as killing scale insects is concerned, but that the peach tree under unfavorable weather conditions, or such as lead to the slow evaporation (and these conditions are not always easily recognizable), is very apt to be killed or badly damaged, and that corresponding damage to other trees is possible, though less likely to result. The general ground taken in 1897, therefore, is adhered to, namely, that the treatment with oil is dangerous and may kill the trees, and its use should never be recommended without calling attention to this possibility, leaving the grower to determine for himself whether he wishes to take the risk or not.

FISH-OIL SOAPS.

The writer has made reports on these soaps at various times, more particularly detailing the results of experiments undertaken to determine the characteristics of the best soap for insecticide purposes, and to detect the deleterious substances or qualities which render many of these soaps unfit for use. The determination of the water constituent of soap, and of the bearing of the latter on the value of the article for insecticide purposes, was one of the first things investigated, and it was demonstrated in the report before the seventh and eighth annual 
meetings of this association that a good fish-oil soap should not contain more than 10 to 15 per cent of water for the hard soaps, and from 25 to 30 per cent for the soft soaps, and that many of the formulas which purported to produce a very cheap soap merely meant a soap swelled to great weight and volume by the very large water content.

The greatest objection to most of the soaps on the market, as often pointed out, is that when dissolved in water at the great strength now employed, a gelatinous mixture results on cooling, which is very diffcult or impossible to spray except at high temperatures difficult to maintain in winter work. The source of this objectionable feature was first supposed to be in the use of the cheaper caustic soda instead of the more expensive caustic potash, the former making a hard soap not readily dissolved in water, and the latter a soft soap and one much more easily soluble.

The possibility that the hard gelatinous quality of certain soaps was due to the use of tallows and other refuse fats, strong in stearin, was also suggested. Examinations and analyses of many different brands of soaps indicated that the difficulty was not entirely explained by the first of these suppositions, showing as they did in the first place that practically all the fish-oil soaps on the market were made with caustic soda, and in the second place that a caustic soda soap did not necessarily present the objectionable feature noted. The second of these suppositions, namely, that the use of waste tallows and fats of that character had something to do with the gelatinizing of soaps in solution, was shown to have some basis in fact, but did not explain the difficulty in all cases.

In examining the process of soap making it seemed that the addition of salt might have some effect in producing a soap which would behave properly in solution, and further, that the addition of lime might have a similar influence. The tests made with salt showed that this substance exerted no effect on the behavior of soap. With lime, on the other hand, it was found that its addition to the soap in solution in sufficient quantity would break it up, so that it would remain of a fluid consistency even when chilled. A true fluid, however, was not obtained, but a granular substance caused by the lime precipitate, such as is seen in the use of soap with hard water.

The cause of the marked gelatinizing of soaps in solution was still far from being satisfactorily explained. What is probably a very frequent if not the usual cause of this difficulty has, I think, now been determined.

It seems that soap makers in the East very frequently cheapen their washing soaps by the addition of silicate of soda, a gelatinous substance costing only about a cent a pound, and, perhaps, not working any serious mischief to the soap for washing purposes, but for all insecticide uses rendering it comparatively valueless.

$7184-$ No. $17 \longrightarrow 7$ 
The writer recommended this substance as an insecticide in July, 1395. ${ }^{1}$ Sereral years of experimental testing have followed, some of the results of which have been reported at rarious sessions of this association.

During the last year or two this substance has also been experimented with by sereral station entomologists and individuals. It is an insecticide which can be used with as great safety as Paris green, and I believe should be recommended by every station entomologist, from the fact that it has the decided adrantage orer Paris green-(1) in costing only one-half as much. and (2) in being a very fine pulverulent powder, which remains easily in suspeusion. It is perhaps slightly more caustic on foliage than Paris green, dne solely to the finer dirision of the powder, as proven by rarious experiments with Paris green, when the latter is ground up somewhat approaching the fineness of arsenite of copper. It now comes from the manufacturers ${ }^{2}$ in a better form than the original samples receired and much freer from soluble arsenic, being thoroughly washed before drying, to remore any uncombined arsenic. In its present form it contains about 50 per cent of arsenic. It is put on the market under the name of green copper arsenite.

\section{INSECTS OF THE YEAR IN OHIO.}

Bт̃ F. M. Webster and C. W. Malir, Wooster, Ohio.

There has so far been no very disastrous outbreak of any insect in Ohio during the present year. Chinch bugs are attracting some attention locally in widely separated localities, but the trouble is less than during the last four years. Canker-worms have been reported from sereral localities. The spring was rather noted for the sudden appearances of swarms of insects, not usually noted, but whose habits are of that mature. The most noted of these was the sudden appearance early in May of great numbers of the pear-tree blister-beetle (Pom. phopeca (enea Say) on the grounds of the experiment station at Wooster, where they covered a very small area in the midst of the orchards, but deroted their entire attention to plum, seemingly ignoring the pear trees which were close by. Anomala unduluta appeared at Bolivar May 14 in the erening and stripped the plum trees, remaining under boards, etc., during the day. At Minerva a fer days later the same insect did considerable injury to the young growth of the pear. A similar appearance of Hoplia trifasciata occurred at Grand Rapids, Ohio, in April, the beetles attacking the cherry trees, eating the foliage, but more especially the petals of the blossoms.

${ }^{2}$ Adler Color and Chemical Co., 96 Maiden Lane, New York 
Of a somewhat similar nature as the foregoing phenomena was the outbreak of Loxotrenia clemensiana in clover meadows in the vicinity of Alliance. The larvæ were excessively abundant, and drew the apical leares together after the manner of leaf rollers in general, and fed within the domicile thus formed, causing the foliage to take on a bromnish color. So abundant were these depredators in many fields that the clover was sufficiently injured to give the field a browned appearance, though the hay crop was probably not injured thereby. In timothy and wheat the larva simply tie the edges of the leaf together, forming a slender tube within which they feed, singly, often pupating therein.

From a mass of dead and dried grape leaves collected May 5, in a vineyard near the lake shore about Gypsum, there emerged between June 3 and July15, great numbers of adults of Pyralis costalis, these being most numerous during June, the larvæ from which they came having in all probability wintered over in the fallen leaves. From this same lot of leaves we secured a considerable number of adult Ampeloglypter sesostris, which must also have hibernated among these fallen leaves, a condition quite the contrary of what Riley supposed, as shown in his First Missouri Report.

A lot of larvæ of Ichthyura apicalis, from Carolina poplar, were put in a breerling cage in September, 1897 , many of these completing their transformations therein. On April 2, and again on the 18th, 1898, there appeared a single adult Pyralis farinalis in this same cage. How these came to be introduced, or what attraction there could possibly be for the larvæ there, in case these made their own way there by working their way in behind the glass slide, as well as what they could have subsisted on after having gotten there is a mystery, at least to us.

Trogoderma ornata was reared from ears of popcorn, the larvie feeding on the kernels. Corn sent by Hon. R. H. Warder, superintendent of parks, Cincinnati.

Chelymorpha argus was reared from larræ found by Mr. S. J. Bennett, Willard, Ohio, on his strawberry vines. Some of these had pupated in transit while others did so in our breeding eages, but without feeding.

Hydnocera rerticalis was reared from galls on or near the ends of twigs of willow, Salix sp.

Mr. J. W. Snider, La Carne, Ohio, reported that in jarring his plum trees for plum curculio more Hagdalis olyra were collected than the former, which were quite abundant. On the experiment station grounds at Wooster, Gymnetron teter was jarred from plum trees May 28, and was observed in great numbers about mullein plants on June 8 at Mantua. In regard to jarring trees for the purpose of catching curculio, there has this year been considerable adverse proof in regard to the value of this measure to the fruit grower, especially where everything that dropped onto the sheet or "catcher" was summarily destroyed. In the first place Aphides of various sorts have been very abundant and especially those attacking plum and cherry. This has given origin to great numbers of Coccinellidæ, especially of several 
species of Coccinella, Adalia bipunctata and Anatis 15.punctata, and these dropped with the curculio and were destroyed. At the station the use of kerosene in connection with the "catchers" was abandoned entirely, and the curculios were separated out and killed, while the Coccinellidse were allowed to escape! Anatis has a habit of pupating on the green plums, and $\pi$ e have received complaint after complaint of their supposed ravages, thus showing a sad deficiency in rudimentary entomology, among what are usually classed as intelligent people. That myriads of these beneficial insects have been slaughtered through misapprehension the present season does not admit of a doubt.

Mr. S. C. C. Shriver, of Shawnee, Ohio, reported with specimens, that what had been termed the "Elephant Corn Bug" had committed serious ravages in his corn planted on bottom land in Butler County, Kans. 'The area of depredation appears to be somewhat limited, covering a small territory, about a mile wide in the southern part of the county and including only two or three farms. The insect sent proved to be the well-known Lixus mucidus, and it is reported to have destroyed the roung corn by puncturing the stalk and eating out the heart. This is believed to be the first report of injury to grain crops by this species.

Rhyssematus palmacollis and Brachytarsus alternatus were sent to us by Dr. J. C. Arthur, who had reared them from galls on the gopher vine, Ipomoea pandurata, caused by a fungus, Cystopus ipomce-pandurance.

Chramesus icorice was reared from larva infesting twigs of walnut collected at East Cleveland, Ohio, April 7, 1898.

Orgyia leucostigma has appeared in overabundance in both Cleveland and Youngstown, but are being overcome by their natural enemies, the Chrysopa being rery abundant, as stated to have been true in the case studied in Washington, D. C., by Dr. Howard.

Pyrrhia umbra was reared July 27 from larvæ found eating into and destroying rosebuds. These larræ entered the ground June 4, had pupated by the 8th, the imagos appearing as stated.

The common cricket (Gryllus abbreviatus) has been accused of working great injury to young, recently transplanted tomato plants, by eating. them off just above the surface of the ground. The same authority, Mr. John A. Bryce, Batavia, Ohio, states that crows destroy the tomato worm to such an extent on his premises that he has no trouble with that insect.

Phytoptus phlccocoptes occurs generally over the State, its attacks being directed more especially to the damson plum, but also appearing to a limited extent on the lombard and other varieties. It is erroneously supposed by many to cause the black knot, the galls being mistaken for the very young knots.

The minute, cosmopolitan parasite (Arrhenophagus chionaspidis) has been reared in great numbers from Diaspis rosce on wild raspberry canes, females only appearing. (See Dr. Howard's paper in Proc. Ent. Soc. 
of Washington, Vol. IV, pp. 133-139, 1898.) A large number of the infested canes were placed in a breeding cage, some of these having in them the eggs of Ecanthus niveus, and when the young hatched they developed within the eage with no other food than was afforded by the growing canes. They were observed to feed on Diaspis rosa, but at the same time there were some appearances of the foliage of the plants that could only be accounted for on the assumption that the tree crickets had fed from them.

In October, 1897, a Japan flowering cherry tree, imported from Japau the winter before and planted out in nursery row in April, was again transplanted to the station grounds at Wooster, being placed outside in order to determine whether or not the Coccid, with which it had evidently been infested when brought from its native home, would survive the frigid climate of our winters. On March 9, 1898, the tree was examined and of five Diaspis amygdali three were dead and two were evidently in a healthy condition. The lowest temperature which these live females had experienced during the winter was $9^{\circ} \mathrm{F}$., on February 2 and 3,1898 . While on July 26, present date, the species does not appear to have thrived at all as well as it did on another tree kept in the insectary, yet there is ample proof that a lower temperature than that given above will be necessary to destroy the scales. For information regarding the second tree, kept indoors, see Can. Ent., Vol. XXX, p. 78,1898 , as it was from the scale of this tree that Archenomus bicolor was reared.

Serious injury to oats by attacks of wireworms was reported from Roachton, May 28, rather an unusual occurrence, especially at this season of the year, and raises anew the question as to a remedial or preventive measure that will apply in fields of growing grain. On October 14, 1897, three plats, each 1 rod square, were selected in a field of wheat suffering badly from the attacks of wireworm, and kainit applied to these on the surface of the ground in varying quantities, the first receiving 2 pounds, or at the rate of 320 pounds per acre; the second 8 pounds, or at the rate of 1,280 pounds per acre, and the third 15 pounds, or at the rate of 2,400 pounds per acre. The soil being at the time very dry, about 6 gallons of water was immediately applied to each plat by sprinkling the surface, and a second similar application was made two days later, after which there were abundant rains. By November 18 the worms had ceased working on the wheat, and on that date an examination was made on these plats, and at depths of from 5 to 12 inches from the surface, but not below this, a number of wireworms were found, apparently in hibernation.

On March 16, 1898, the plats were again examined, and samples of the soil taken for chemical aualysis. Although samples were removed from all three of the plats, as a matter of fact only those from the last plat, or the one receiving the greatest amount of kainit were used, as the results here seemed sufficiently conclusive. The ground at the 
time was thoroughly saturated with water, and at a depth of from 11 to 12 inches from the surface in the last or most strongly fertilized plat sample 3 of this plat was taken. An examination of this sample after it had been removed to the laboratory revealed the presence of three small, partly grown wireworms, alive, and to all appearances perfectly healthy, and still in their place of hibernation. As will be observed by the analyses, this sample gave the strongest reaction when tested for chlorine.

These tests were made by Mr. L. M. Bloomfield, at that time assistant chemist of the Ohio Agricultural Experiment Station, and in the following manner: Of each sample 500 grams were digested in 1,000 cubic centimeters of distilled water for six hours, and in 100 cubic centimeters of the filtrate, equal to 50 grams of soil, the chlorine being determined volumetrically by a solution of nitrate of silver, 1 cubic centimeter of which equals 0.003546 gram of chlorine.

The following are the results of the analyses, all being, as has been stated, from different depths in the plat on which kainit had been applied at the rate of 2,400 pounds to the acre, and it was in sample No. 3 that the young wireworms had evidently passed the winter:

Sample No. 1, from surface to a depth of $1 \frac{1}{2}$ inches, gave 0.0039006 gram chlorine.

Sample No. 2, from depth of 5 to 7 inches, gave 0.0063828 gram chlorine.

Sample No.3, from depth of 11 to 12 inches, gave 0.0078012 gram chlorine.

The soil of check plat, to which no kainit had been applied, tested as follows:

Sample No. 1 gave 0.001773 gram chlorine.

Sample No. 2 gave 0.001773 gram chlorine.

Sample No. 3 gave 0.0014184 gram chlorine.

The check samples were of course taken from the same depth as those from the treated plat. These results would seem to indicate that no reasonable amount of kainit applied to fields will either destroy or drive away wireworms. Also, it is interesting to note that at a depth of 1 foot from the surface there was almost double the amount of kainit present, nearly all of which must have been encountered by the worm on its way downward. 


\section{LIST OF THE MEMBERS OF THE ASSOCIATION OF ECONOMIC ENTOMOLOGISTS.}

\section{ACTIVE MENBERS.}

Adams, M. F., Buffalo, N. Y.

Aldrich, J. M., Moscow, Idaho.

Alwood, William B., Blacksburg, Va.

Ashmead, William H., Washington, D. C.

Baker, C. F., Auburn, Ala.

Ball, E. D., Fort Collins, Colo.

Banks, Nathan, Washington, D. C.

Beckwith, M. H., Elmira, N. Y.

Bethune, C. J. S., Port Hope, Can.

Bogue, E. E., Stillwater, Okla.

Bruner, Lawrence, Lincoln, Nebr.

Bullard, W. S., Bridgeport, Comn.

Britton, W. E., New Haven, Conn.

Burgess, Albert F., Malden, Mass.

Campbell, J. P., Athens, Ga.

Chambliss, C. E., Knoxville, Tenn.

Chittenden, F. H., Washington, D. C.

Cockerell, T. D. A., Mesilla, N. Mex.

Collins, Lewis, Brooklyn, N. Y.

Comstock, J, H., Ithaca, N. Y.

Cook, A. J., Claremont, Cal.

Cooley, R. A., Amherst, Mass.

Coquillett, D. W., Washington, D. C.

Cordley, A. B., Corvallis, Oreg.

Davis, G. C., Los Angeles, Cal.

Doran, E. W., Clinton, Mo.

Ehrhorn, E. M., Mountain View, Cal.

Felt, Ephraim P., Albans, N. Y.

Fernald, C. H., Amherst, Mass.

Fernald, H. T., Harrisburg, Pa.

Fiske, IT. F., Durham, N. H.

Fletcher, James, Ottawa, Canada.

Forbes, S. A., Urbana, Ill.

Forbush, E. H., Malden, Mass.

Frost, H. L., Boston, Mass.

Garman, H., Lexington, Ky.

Gifford, John, Mays Landing, N. J.

Gillette, C. P., Fort Collins, Colo.

Goriing, F. W., Rutland, Ill.

Gossard, H. A., Ames, Iowa.

Hargitt, C. WV., Syracuse, N. Y.

Harrington, W. H., Ottawa, Canada.

Hart, C. A., Urbana, Ill.

Harvey, F. L., Orono, Me.

Hillman, F. H., Reno, Nev.
Hine, J. S., Columbus, Ohio.

Hopkins, A. D., Morgantown, W. Va.

Howard, L. O., Washington, D. C.

Hubbard, H. G., Washington, D. C.

Hudson, G. H., Plattsburg, N. I.

Hulst, G. D., Brooklyn, N. Y.

Jolmson, W. G., College Park, Md.

King, George B., Lawrence, Mass.

Kirkland, A. H., Malden, Mass.

Lowe, V. H., Geneva, N. Y.

Lugger, Otto, St. Anthony Park, Mimn.

MeCarthy, Gerald, Raleigh, N. C.

Mally, C. Wr., Wooster, Ohio.

Mann, B. P., Washington, D. C.

Marlatt, C. L., Washington, D. C.

Morgan, H. A., Baton Rouge, La.

Mosher, F. N., Malden, Mass.

Murtfeldt, Miss M. E., Kirkwood, Mo.

Niswander, F. J., Cheyenne, IVyo.

Osborn, Herbert, Columbus, Ohio.

Packard, A. S., Providence, R. I.

Palmer, R. M., Victoria, British Columbia.

Pergande, Th., Washington, D. C.

Perkins, G. H., Burlington, Vt.

Phillips, J. L., Blacksburg, Va.

Popenoe, E. A., Manhattan, Kans.

Quaintance, A. L., Lake City, Fla.

Rane, F. W.., Durham, N. H.

Reed, E. B., Esquimault, Brit. Columbia.

Rolfs, P. H., Lake City, Fla.

Rumsey, W. E., Morgantown, WV. Va.

Sanderson, E. Dwight, College Park, Md.

Saunders, William, Ottawa, Canada.

Schwarz, E. A., Washington, D. C.

Scott, W. M., Atlanta, Ga.

Sherman, Franklin, jr., College Park, Md.

Sirrine, F. A., Jamaica, N. Y.

Slingerland, M. V., Ithaca, N. Y.

Smith, J. B., New Brunswick, N. J.

Snow, F. H., Lawrence, Kans.

Southwick, E. B., New York, N.Y.

Stedman, J. M., Columbia, Mo.

Stimson, James, Watsonville, Cal.

Summers, H. E., Ames, Iowa.

Test, F. C., Dundee, Ill. 
Thaxter, Roland, Cambridge, Mass.

Toumey, J. W., Tueson, Ariz.

Townsend, C. H. T., Las Cruces, N. Mex.

Washburn, F. L., Eugene, Oreg.

Webster, F. M., Wooster, Ohio.
Weed, C. M., Durham, N. H. Weed, H. E., New Orleans, La. Wilcox, E. V., Bozeman, Mont. Woodworth, C. W., Berkeley, Cal.

\section{FOREIGN MEMBERS.}

Berlese, Dr. Antonio, R. Scuola Superiore di Agricoltura, Portici, Italy. Bos, Dr. J. Ritzema, Amsterdam, Netherlands.

Carpenter, Prof. George H., Nat. Hist. Nus., Dublin, Ireland.

Cholodkowsky, Prof. Dr. N., Institut Forestier, St. Petersburg Russia.

Cotes, E. C., 201 Iffley Road, Oxford, England.

Danysz, J., Laboratoire de Parasitologie, Bourse de Commerce, Paris, France.

Enock, Fred., 21 Manor Gardens, Holloway, London, England.

French, Charles, Melbourne, Australia.

Froggatt, W. W., Sidney, New South Wales.

Fuller, Clande, Department of Agriculture, Cape Town, South Africa.

Giard, A., 14 rue Stanislaus, Paris, France.

Grasby, W. C., Parkside, Adelaide, South Australia.

Helm, Richard, Perth, West Australia.

Horvath, Dr. G., Musée Nationale Hongroise, Budapest, Hungary. Lampa, Prof. Sven, Department of Agriculture, Stockholm, Sweden.

Lindeman, Dr. K., Landwirthschaftliche Akademie, Moscow, Russia.

Lounsbury, Charles P., Department of Agriculture, Cape Town, South Africa.

Marchal, Dr. Paul, 16 Rue Claude Bernard, Paris, France.

Musson, Chas. T., Hawkesbury Agricultural College, Richmond, New South Wales.

Ormerod, Miss Eleanor A., Torrington House, St. Albans, England.

Portschinsky, Prof. A., Ministère de l'Agriculture, St. Petersburg, Russia.

Reed, E. C., Rancagua, Chile.

Reuter, Dr. Enzio, Fredriksgatan 45, Helsingfors, Finland, Russia.

Schöyen, Prof. W. M., Christiania, Norway.

Shipley, Prof. Arthur E., Cambridge, England.

Targioni-Tozzetti, Prof. A., R. Staz. d. Entom. Agrar., Florence, Italy.

Theobald, Frederick B., Wyecourt, County Kent, England.

Thompson, Rev. Edward H., Franklin, Tasmania.

Tryon, H., Brisbane, Queensland, Australia.

Urich, F. W., Arima, Trinidad, West Indies.

Termorel, V., Villefranche, Rhône, France.

Whitehead, Charles, Barming House, Maidstone, Kent, England. 

